DiRECTEUR de LA PUBLICATION / PUBLICATION DIRECTOR: Bruno David

Président du Muséum national d'Histoire naturelle

RÉDACTRICE EN CHEF / EDITOR-IN-CHIEF : Laure Desutter-Grandcolas

AsSISTANTE DE RÉDACTION / AsSISTANT EDITOR: Anne Mabille (zoosyst@mnhn.fr)

Mise en page / Page Layout: Anne Mabille

COMITÉ SCIENTIFIQUE / SCIENTIFIC BOARD:

Nesrine Akkari (Naturhistorisches Museum, Vienne, Autriche)

Maria Marta Cigliano (Museo de La Plata, La Plata, Argentine)

Serge Gofas (Universidad de Málaga, Málaga, Espagne)

Sylvain Hugel (CNRS, Université de Strasbourg, France)

Marco Isaia (Università degli Studi di Torino, Turin, Italie)

Rafael Marquez (CSIC, Madrid, Espagne)

Jose Christopher E. Mendoza (Lee Kong Chian Natural History Museum, Singapour)

Annemarie Ohler (MNHN, Paris, France)

Jean-Yves Rasplus (INRA, Montferrier-sur-Lez, France)

Wanda M. Weiner (Polish Academy of Sciences, Cracovie, Pologne)

COUVERTURE / COVER:

Réalisée à partir de différentes planches de Lesueur reproduites dans cet article (avec l'aimable autorisation du Muséum d'Histoire naturelle du Havre)/Made from various plates by Lesueur reproduced in this article (with the kind permission of the Natural History Museum of Le Havre).

Zoosystema est indexé dans / Zoosystema is indexed in:

- Science Citation Index Expanded (SciSearch $\left.{ }^{\circledR}\right)$

- ISI Alerting Services ${ }^{\circledR}$

- Current Contents ${ }^{\circledR}$ / Agriculture, Biology, and Environmental Sciences ${ }^{\circledR}$

- Scopus ${ }^{\circledR}$

Zoosystema est distribué en version électronique par / Zoosystema is distributed electronically by:

- BioOne ${ }^{\circledR}$ (http://www.bioone.org)

Les articles ainsi que les nouveautés nomenclaturales publiés dans Zoosystema sont référencés par / Articles and nomenclatural novelties published in Zoosystema are referenced by:

- ZooBank ${ }^{\circledR}$ (http://zoobank.org)

Zoosystema est une revue en flux continu publiée par les Publications scientifiques du Muséum, Paris / Zoosystema is a fast track journal published by the Museum Science Press, Paris

Les Publications scientifiques du Muséum publient aussi / The Museum Science Press also publish:

Adansonia, Geodiversitas, Anthropozoologica, European Journal of Taxonomy, Naturae, Cryptogamie sous-sections Algologie, Bryologie, Mycologie.

Diffusion - Publications scientifiques Muséum national d'Histoire naturelle

CP $41-57$ rue Cuvier F-75231 Paris cedex 05 (France)

Tél. : 33 (0)1 40794805 / Fax: 33 (0)1 40793840

diff.pub@mnhn.fr / https://sciencepress.mnhn.fr

(C) Publications scientifiques du Muséum national d'Histoire naturelle, Paris, 2021

ISSN (imprimé / print): 1280-9551/ ISSN (électronique / electronic): 1638-9387 


\section{The asteroid species of Lamarck (Echinodermata: Asteroidea)}

Michel JANGOUX

Laboratoire de Biologie marine, Université Libre de Bruxelles, 50 avenue F. D. Roosevelt, B-1050 Bruxelles (Belgium) and Laboratoire de Biologie marine, Université de Mons, 20 Place du Parc, B-7000 Mons (Belgium)

Submitted on 24 February 2020 | Accepted on 11 May 2020 | Published on 11 May 2021

urn:Isid:zoobank.org:pub:47EAA3BE-82DB-4363-BA57-43F4CF508AC6

Jangoux M. 2021. - The asteroid species of Lamarck (Echinodermata: Asteroidea). Zoosystema 43 (13): 213-252. https://doi.org/10.5252/zoosystema2021v43a13. http://zoosystema.com/43/13

\section{ABSTRACT}

Zoologist Péron and artist Lesueur, both members of the scientific staff of the Baudin expedition to the Southern Lands (September 1800-March 1804), collected during their voyage 36 different species of asteroids. This is what wrote Lamarck in a report made in June 1804. This number was clearly reduced by Lamarck himself who, in his 1816 publication, listed only 15 species from the South Seas in the Paris Museum collection. However, the different asteroids collected during the expedition were drawn by Lesueur (water colours and pencil drawings) who thus realised a real pictorial register. Lesueur's drawings are housed in the Le Havre Museum. Due to their realism and precision, the drawings make it easy to identify the species. Confrontation of Lamarck's report (1804) and publication (1816) with Lesueur's drawings (done between 1802 and 1804) gives a new, more precise idea of the importance of the collection of South Seas asteroids brought back to France and allows to reliably count the number of new species that it contained. Also, this makes it possible to complete the often too brief descriptions of some Lamarckian species and to clarify their status. Eleven taxonomic changes are thus

KEY WORDS

Lesueur, Asteroidea, Echinodermeta, sea stars, Australia, Tasmania, Baudin expedition new synonymies, new combination. proposed here: Asterias calcar var. quinqueangula is synonymized with Parvulastra exigua (Lamarck, 1816), Asterias calcitrapa var. 1 with Bollonaster pectinatus (Sladen, 1883), Asterias calcitrapa var. 2 with Astropecten vappa Müller \& Troschel, 1843, Asterias nodosa var. 3 with Protoreaster lincki (Blainville, 1830), Asterias pentagonula with Tosia australis Gray, 1840, Asterias pleyadella with Protoreaster sp., Asterias punctata with Asteropsis carinifera (Lamarck, 1816), Asterias rosacea var. lobis senis with Anseropoda sp., Asteriscus setaceus with Paranepanthia grandis (H. L. Clark, 1928), Astrogonium lamarckii Müller \& Troschel, 1842 with Goniaster tessellatus (Lamarck, 1816) and Asterias cuspidata is moved to the genus Mediaster Stimpson, 1857 as Mediaster cuspidatus (Lamarck, 1816) n. comb.

\section{RÉSUMÉ}

Les espèces d'astéries de Lamarck (Echinodermata: Asteroidea).

Le zoologiste Péron et le dessinateur Lesueur, membres de l'équipe scientifique de l'expédition Baudin aux Terres australes (septembre 1800-mars 1804), y ont récolté, selon un rapport de Lamarck daté de juin 1804, 36 espèces différentes d'astéries. Ce nombre fut nettement réduit, en 1816, par Lamarck lui-même qui ne répertoria que 15 espèces d'origine australe dans les collections du muséum de Paris. Or, les différentes astéries récoltées pendant l'expédition furent dessinées par Lesueur (aquarelles et crayonnés) qui en réalisa un véritable registre pictural. Conservés au muséum du Havre, les dessins de Lesueur, par leur réalisme et leur précision, permettent aisément d'identifier les espèces. La confrontation du rapport de Lamarck (1804) et de sa publication (1816) avec les dessins de Lesueur (réalisés entre 1802 et 1804) donne une image précise et nouvelle de l'importance de la collection d'astéries ramenée à l'époque en France et permet de déterminer 


\author{
MOTS CLÉS \\ Lesueur, \\ Asteroidea, \\ Echinodermeta, \\ étoiles de mer, \\ Australie, \\ expédition Baudin, \\ synonymies nouvelles, \\ combinaison nouvelle.
}

fiablement le nombre de nouvelles espèces australes recueillies alors. Une confrontation qui a également permis de compléter les descriptions, souvent très brèves, de certaines des espèces d'astéries établies par Lamarck et d'éclaircir leur statut. Onze changements taxonomiques sont ainsi proposés ici : Asterias calcar var. quinqueangula est synonyme de Parvulastra exigua (Lamarck, 1816), Asterias calcitrapa var. 1 de Bollonaster pectinatus (Sladen, 1883), Asterias calcitrapa var. 2 de Astropecten vappa Müller \& Troschel, 1843, Asterias nodosa var. 3 de Protoreaster lincki (Blainville, 1830), Asterias pentagonula de Tosia australis Gray, 1840, Asterias pleyadella de Protoreaster sp., Asterias punctata de Asteropsis carinifera (Lamarck, 1816), Asterias rosacea var. lobis senis de Anseropoda sp., Asteriscus setaceus de Paranepanthia grandis (H. L. Clark, 1928), Astrogonium lamarckii Müller \& Troschel, 1842 de Goniaster tessellatus (Lamarck, 1816) et Asterias cuspidata est transférée dans le genre Mediaster Stimpson, 1857 en tant que Mediaster cuspidatus (Lamarck, 1816) n. comb.

\section{INTRODUCTION}

The part devoted to asteroids in the second volume of Lamarck's Histoire naturelle des Animaux sans Vertèbres (1816) reports on 44 species and 23 varieties. Some of the new species Lamarck then described originated from European seas and the Atlantic and Indian coasts of Africa though most came from Australian coasts. Indeed, the Paris Museum had received the very large collection of sea stars made during the Voyage de Découvertes aux Terres australes, the so-called Baudin expedition, in the early nineteen century (1800-1804). The main collectors of this collection were the zoologist François Péron and his friend the artist Charles-Alexandre Lesueur, both members of the expedition scientific staff sailing on the vessel Le Géographe.

The collections of the Baudin expedition reached the Muséum national d'Histoire naturelle (MNHN) at the end of April 1804. Two months later Lamarck presented several reports on invertebrates to his colleagues at the Muséum; one of which dealing with echinoderms (Jangoux in press). The collection of asteroid contains 264 individuals representing, Lamarck wrote, 36 different species of Asterias, many of which were, he said, new. What he did not know at the time was that the asteroids collected were drawn (watercolours and pencil drawings) by Lesueur, the expedition artist. Fortunately, Lesueur's drawings have been preserved and kept in good condition, being housed since the last quarter of the 19th century in the Muséum d'Histoire naturelle du Havre (MHNH) (the complicated story of these drawings and their progressive acquisition by the MHNH is detailed in Bonnemains [1995]). There are 53 groups of asteroids drawings in the Lesueur's collection. They are very realistic and most of them allow identification of species. Moreover, they are so precise that some show the arrangement of skeletal plates and details on their spine armament. Based on these drawings, the number of species collected was assessed at about 50 (Jangoux 1984), more than the 36 species reported by Lamarck in 1804, and still much more than the 15 species collected by Péron and Lesueur that Lamarck (1816) said he found in the MNHN.

The number of species collected during Baudin's voyage differs distinctly according to the sources $(50,36$ or 15$)$ without knowing the exact number of new species collected by Péron and Lesueur, except that it should be more than 15! Lesueur's drawings of asteroids only concern the individuals of the Baudin expedition. He thus made a pictorial register representing almost all the asteroids that reached the Muséum in April 1804. Thus, two groups of new species from the South Seas should be considered: those described by Lamarck in 1816, and those not reported by Lamarck in 1816, although the specimens have been seen, counted and sorted by him when the collected material reached the Muséum in 1804.

The Baudin expedition is well documented and, while Lamarck rarely cites the collecting localities (in most cases he writes "originated from the South Seas" or even more allusively "from the voyage of Péron and Lesueur") they can be found in various archives. Collections were made in West Australia (Geographe Bay, Swan River, Barren Islands [Bernier and Dorre Islands], Shark Bay, Depuch Island, King George Sound [Albany]), Tasmania (d'Entrecasteaux Channel, Maria Island, King Island), New South Wales (Port Jackson), South Australia (Kangaroo Island, Saint Peter and Franklin Islands) (Table 1). Other non-Australian collecting localities were Timor (Kupang Bay), Mauritius, and the Cape of Good Hope.

The taxonomic status of every Lamarckian species, whatever its origin, is presented or briefly discussed hereafter. As for the species collected during the Baudin expedition, their drawings are reproduced (Lesueur's watercolours). Among them are those that, although sorted by Lamarck in 1804 and drawn by Lesueur, were not reported in Lamarck's (1816) treatise. The latter were described by subsequent authors and are presented under their original names.

The species are presented according to the alphabetical order of the specific names used in the original descriptions. Information provided consists of: the species name, the original bibliographic reference, the species current status (possibly, revised), the examined material, the species distribution, any additional relevant information (under the heading 'Remark').

\section{MATERIAL AND METHODS}

Two lists of asteroids have been drawn up. The first consists in all the new species established by Lamarck in his 1816 publication, whatever their geographical origin. The second brings together the species collected during the Baudin expedition (1800-1804), mainly in Australia and Tasmania. These were all drawn by Lesueur, and deposited in the Muséum where Lamarck received them in June 1804. The identifications were made from photographs of Lesueur's original drawings. 
Whether or not the species are still present in the MNHN, the two lists make it possible to reconstruct the Parisian asteroid collection and its singularity at the beginning of the 19 th century.

ABBREVIATIONS

MHNH Muséum d'Histoire naturelle du Havre, Le Havre;

MNHN Muséum national d'Histoire naturelle, Paris.

\section{LIST OF ASTEROID SPECIES}

\section{africanus Müller \& Troschel, 1842, Asteracanthion} (Fig. 1)

Asteracanthion africanus Müller \& Troschel, 1842: 15.

Marthasterias africana - Wright et al. 2016: 446.

CURRENT STATUS. — Marthasterias a fricana (Müller \& Troschel, 1842).

Material eXAmined. - MHNH; Lesueur drawings collection; ref. 74026; Baudin expedition; Péron and Lesueur leg.

Distribution. - Southernmost part of Africa.

\section{REMARK}

Now recognised as a valid species, $M$. africana, since its description in 1842, was considered a variety or form of the common European asteroid Marthasterias glacialis (Linnaeus, 1758) (e.g. Mortensen 1933; Clark \& Courtman-Stock 1976). Péron and Lesueur collected individuals of this common species when staying in the Cape of Good Hope area on their way back to France. Péron and Lesueur's material of A. africanus could not be found in the MNHN.

angulatus Müller \& Troschel, 1842, Archaster

(Fig. 2)

Archaster angulatus Müller \& Troschel, 1842: 66. — Sukarno \& Jangoux 1977: 830. — Clark 1993: 238.

Current status. — Archaster angulatus Müller \& Troschel, 1842.

MATERIAL EXAMINED. - MHNH; Lesueur drawings collection; ref. 74044 and 74060; Baudin expedition; Péron and Lesueur legs.

DisTRIBUTION. - The species commonly occurs along the west and north coasts of Australia; it is also reported from South China Sea and the Philippines.

REMARK

Péron and Lesueur's material of $A$. angulatus could not be found in the MNHN.

australiae Döderlein, 1915, Anthenea

(Fig. 3)

Anthenea australiae Döderlein, 1915: 52.
TABLE 1. - Baudin expedition: releases and moorings.

\begin{tabular}{|c|c|}
\hline Areas of collecting & Periods of collecting \\
\hline Geographe Bay & 31.V-9.VI.1801 \\
\hline Shark Bay, Barren Islands (1st stay) & 29.VI-11.VII.1801 \\
\hline Depuch Island & 17-18.VII.1801 \\
\hline Kupang Bay, Timor (1st stay) & 22.VIII-13.XI.1801 \\
\hline D'Entrecasteaux Channel, Tasmania & $20.1-17.11 .1802$ \\
\hline Maria Island, Tasmania & 17-22.II.1802 \\
\hline Port Jackson (Sydney) & 17.VI-18.XI.1802 \\
\hline King Island, Tasmania & 7-13.XII.1802 \\
\hline Kangaroo Island & $6.1-1.11 .1803$ \\
\hline Saint Peter and Franklin Islands & 7-11.II.1803 \\
\hline King George Sound & 18.II-1.III.1803 \\
\hline Shark Bay (2nd stay) & 19-23.III.1803 \\
\hline Kupang Bay, Timor (2nd stay) & 6.V-3.VI.1803 \\
\hline Mauritius & 7.VIII-16.X.1803 \\
\hline Cape of Good Hope & 5-26.I.1804 \\
\hline
\end{tabular}

CURRENT STATUS. - Anthenea australiae Döderlein, 1915.

Material EXAMINED. - MNHN-IE-2014-542; 1 specimen; Baudin expedition (1800-1804); Péron and Lesueur leg. [formerly identified as syntype of Asterias pentagonula] • MNHN-IE-2014-543; 1 specimen; same origin as precedent [formerly identified as syntype of Asterias pentagonula] $-\mathrm{MHNH}$; Lesueur drawings collection; ref. 74052; Baudin expedition.

Distribution. - West and north-west Australian coasts.

REMARK

The MNHN houses two individuals of Döderlein's Anthenea australiae under the name Anthenea pentagonula (Lamarck, 1816), a misidentification resulting from an earlier confusion about the status of Lamarck's Asterias pentagonula (further explanation under that species).

calcar var. octogona Lamarck, 1816, Asterias (Fig. 4)

Asterias calcar var. octogona Lamarck, 1816: 557.

Asteriscus australis (part) Müller \& Troschel, 1842: 43.

Meridiastra calcar - Clark 1993: 224. — O’Loughlin \& Waters 2004: 3 .

Patiriella calcar-Clark in Clark \& Mah 2001: 252.

CURRENT STATUS. - Meridiastra calcar (Lamarck, 1816).

Material EXAMINED. - Australia • MNHN-IE-2014-248; holotype; King George Sound, Albany; Baudin expedition (1800-1804); Péron and Lesueur leg. $\bullet \mathrm{MHNH}$; Lesueur drawings collection ref. 74039; Baudin expedition.

Distribution. - South and east coasts of Australia, Tasmania.

\section{REMARKS}

Three varieties of Asterias calcar were briefly described by Lamarck - viz. hexagona, octogona and quinqueangula - whose individuals were collected in Australian waters (King George Sound [Albany], West Australia) and are still in the MNHN. 

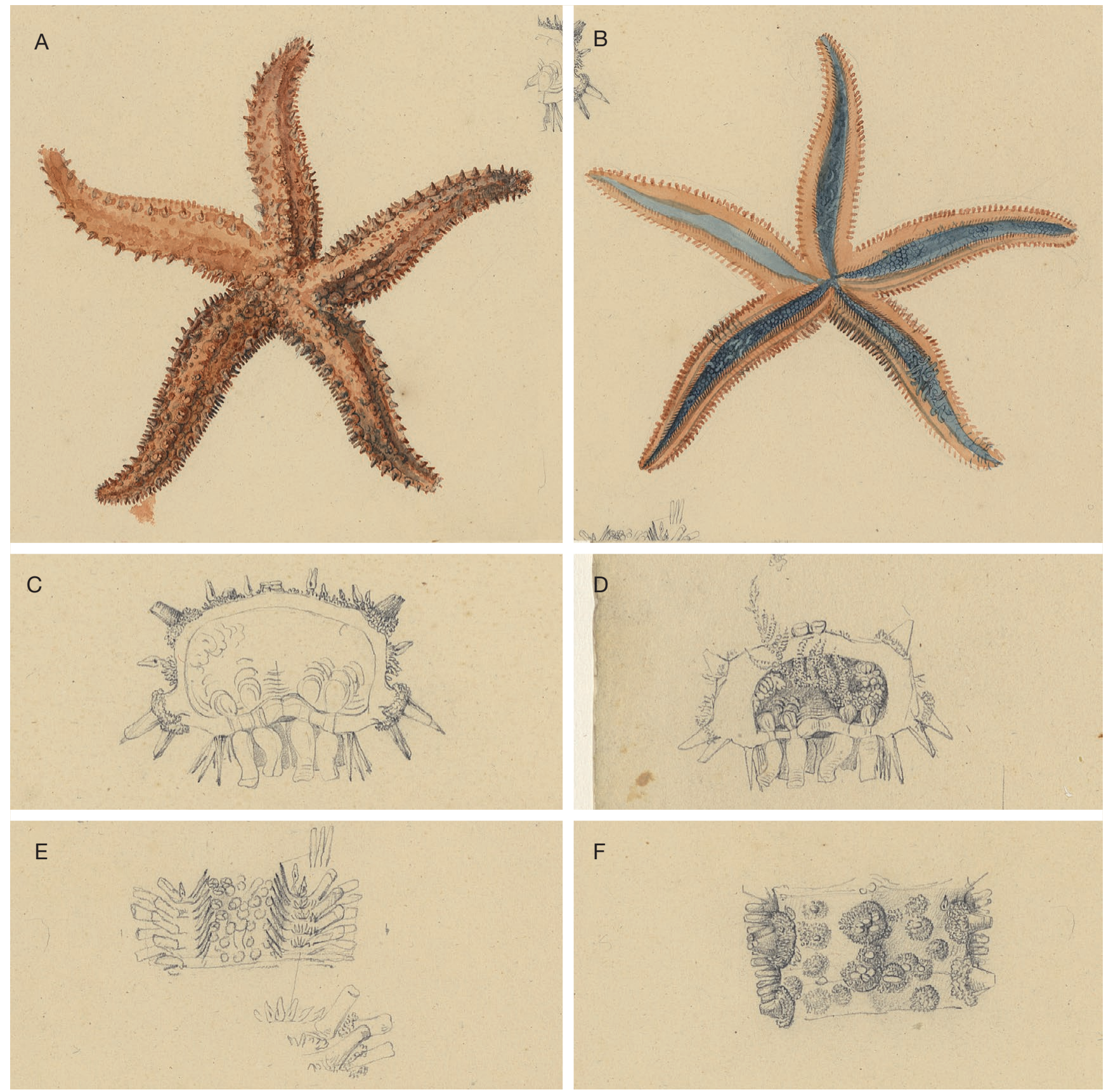

FIG. 1. - Asteracanthion africanus Müller \& Troschel, 1842: A, B, abactinal (A) and actinal (B) surfaces; C, D, arm cross sections with gonad structure (D); E, arm actinal surface showing adambulacral spines; F, abactinal spines surrounded by rings of crossed pedicellariae (Lesueur collection 74026 , details, courtesy of MHNH).

Lamarck reported their colour in life from a Lesueur drawing and without distinguishing the varieties ("Cette astérie est rouge, violette, brillante de couleur, et ressemble à une fleur lorsqu'elle est vivante [this sea star is red, violet, of brilliant colours and looks like a flower when alive]"). Lesueur's drawings indicate these colours should at least characterize individuals of the variety octogona.

The type specimen of Asterias calcar var. octogona was not recognised by Müller \& Troschel (1842) who made it one of the types of their new species, Asteriscus australis. calcar var. hexagona Lamarck, 1816, Asterias

(Fig. 5)

Asterias calcar var. hexagona Lamarck, 1816: 557.

Asteriscus australis (part.) Müller \& Troschel, 1842: 43.

Meridiastra gunni - Clark 1993: 225. - O'Loughlin \& Waters 2004: 3.

CuRrent status. - Meridiastra gunni (Gray, 1840). 

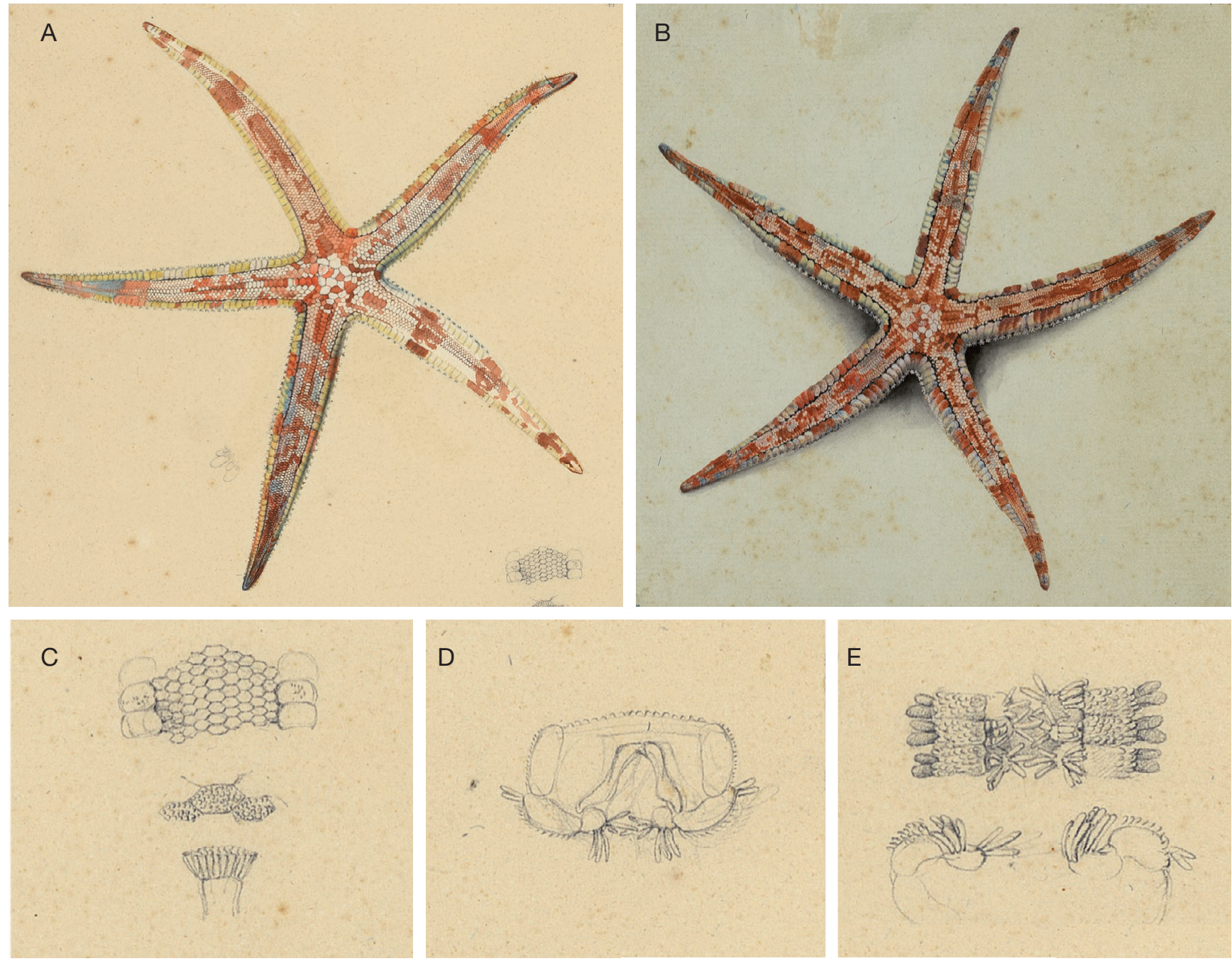

FIG. 2. - Archaster angulatus Müller \& Troschel, 1842: A, B, abactinal surface of two individuals; C, arrangement and details of abactinal paxillae; D, arm cross-section showing the arrangement of arm plates; $\mathbf{E}$, adambulacral armament and inferomarginal plates (Lesueur collection 74044 and 74060 details, courtesy of MHNH).

MATERIAL EXAMINED. - MNHN-IE-2014-508; holotype; King George Sound, Albany; Baudin expedition (1800-1804); Péron and Lesueur leg. • MHNH; Lesueur drawings collection; ref. 74003; Baudin expedition.

Distribution. — SW to SE Australia, Tasmania.

\section{REMARK}

The type specimen of Asterias calcar var. hexagona was not recognised by Müller \& Troschel (1842) who made it one of the types of their new species, Asteriscus australis.

\section{calcar var. quinqueangula Lamarck, 1816, Asterias} (Fig. 15C)

Asterias calcar var. quinqueangula Lamarck, 1816: 557.

Patiriella regularis - Clark 1993: 226.
CURRENT STATUS. - Asterias calcar var. quinqueangula is newly synonymized here with Parvulastra exigua (Lamarck, 1816).

MATERIAl EXAMINED. - Australia • MNHN-IE-2014-30: Asterias calcar var. quinqueangula; 4 syntypes; Australia (King George Sound, Albany); Baudin expedition (1800-1804); Péron and Lesueur leg.

\section{REMARK}

Since the publication of Perrier (1875: 299), Lamarck quinqueangula variety was considered a synonym of the common New Zealand asterinid, Patiriella regularis (Verrill, 1867). Yet this should be reconsidered. Indeed, although the presence of $P$. regularis in Australian waters, mostly Tasmanian, is proven, this presence is however recent. In fact $P$. regularis, a species endemic to New Zealand, is said to have invaded Australian waters in the 20th century after 1930 (Dartnall 1969). This makes it rather unlikely that it was collected by Péron and Lesueur in South Australia or Tasmania in the early 19th century. The status of quinqueangula variety is discussed further under the species Asterias exigua. 

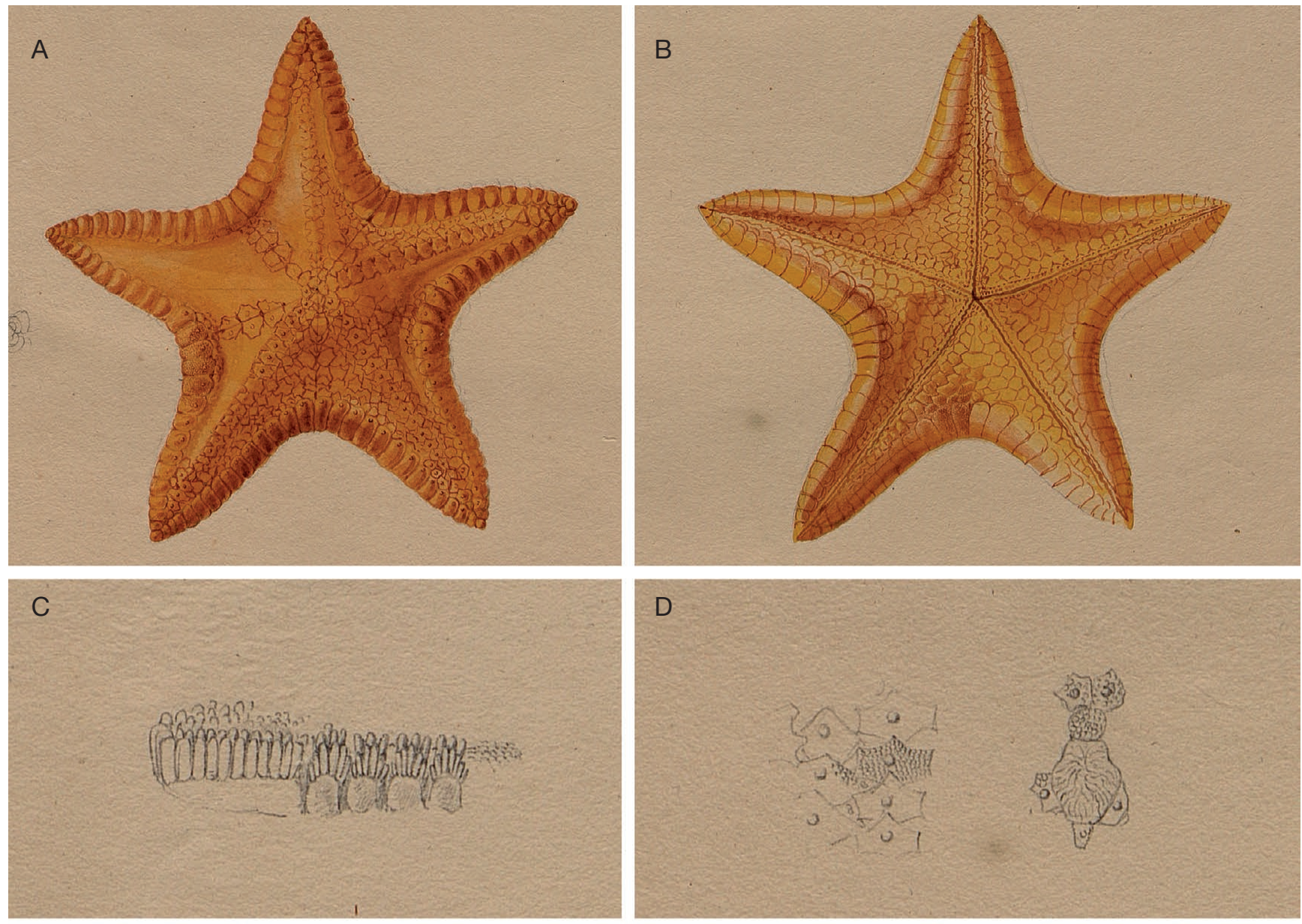

D

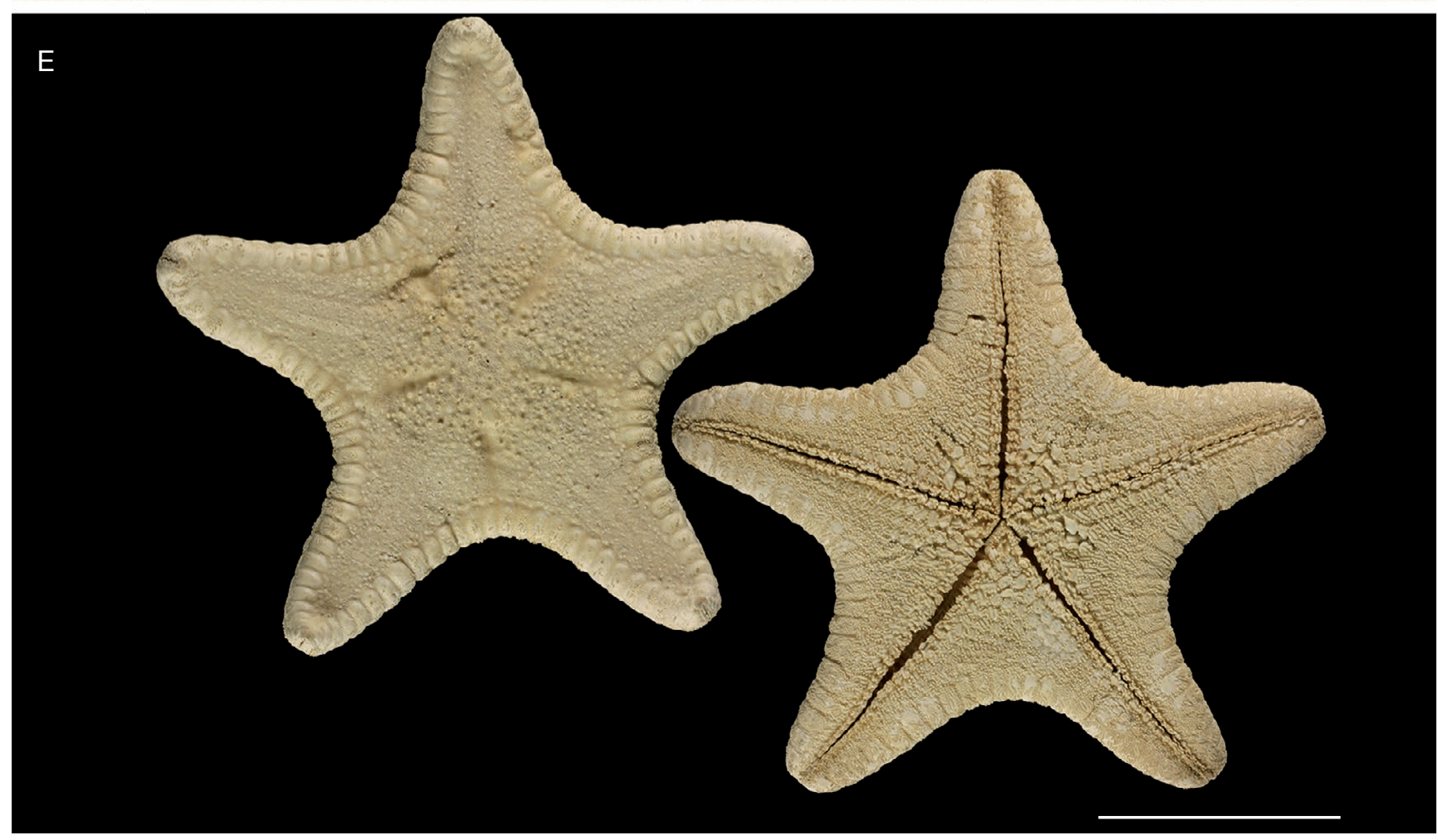

FIG. 3. - Anthenea australiae Döderlein, 1915: A, B, abactinal and actinal surfaces; C, interradial arc and adambulacral spines and plates; D, madreporite and abactinal plates; E, specimen of $A$. australiae from the Baudin expedition [syntype of Asterias pentagonula] (A-D, Lesueur collection 74052, details, courtesy of MHNH; E, MNHN-IE-2014-543). Scale bar: D, $50 \mathrm{~mm}$. 

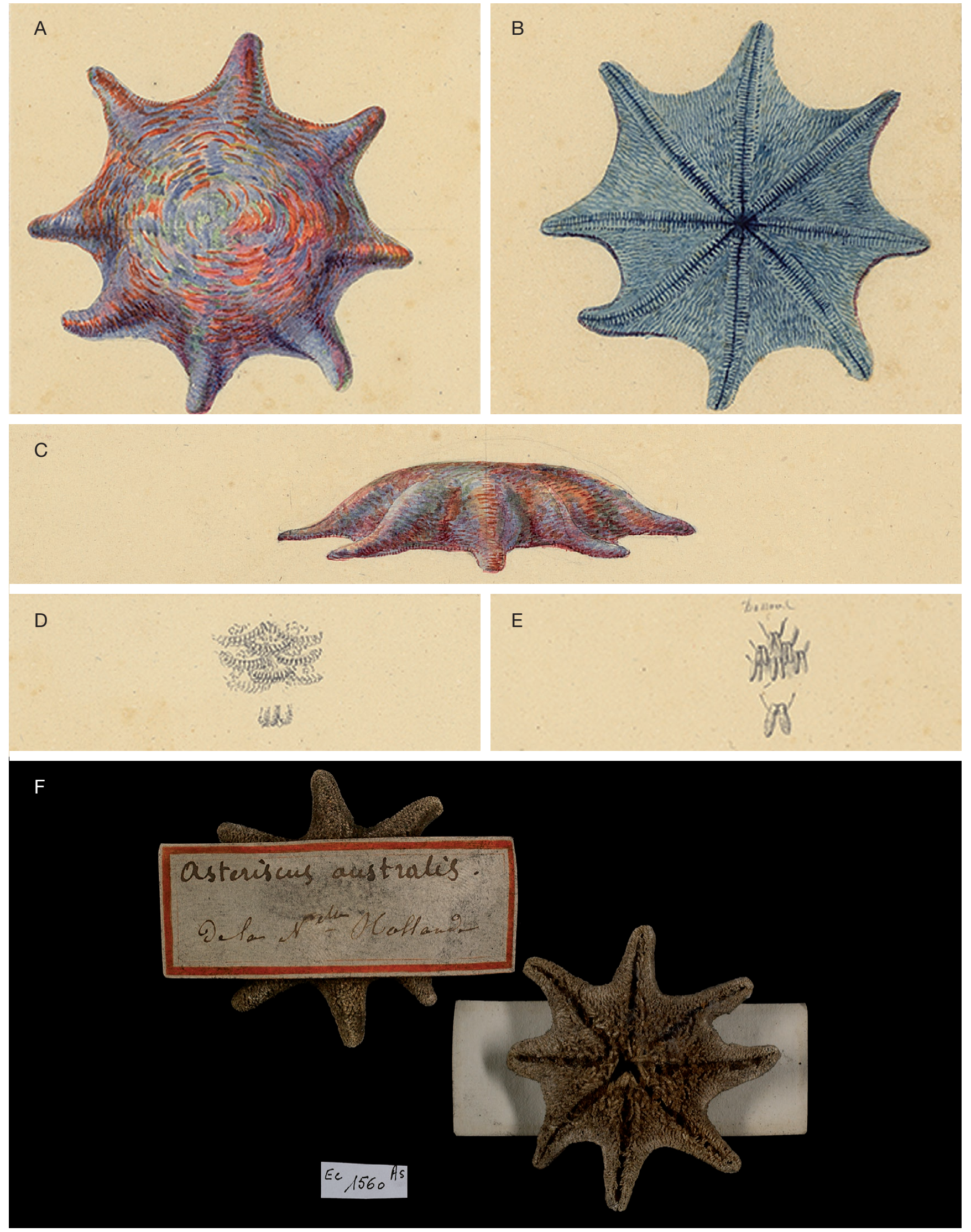

FIG. 4. - Asterias calcar var. octogona Lamarck, 1816: A, B, abactinal (A) and actinal (B) surfaces; C, profile view; D, armament of abactinal plates; E, actinolateral plates and adambulacral spines (text: "dessous" [underside); F, holotype of Meridiastra calcar (Lamarck, 1816) (A-E, Lesueur collection ref. 74039, details, courtesy of MHNH; F, MNHN-IE-2014-248). Scale bar: F, 20 mm. 

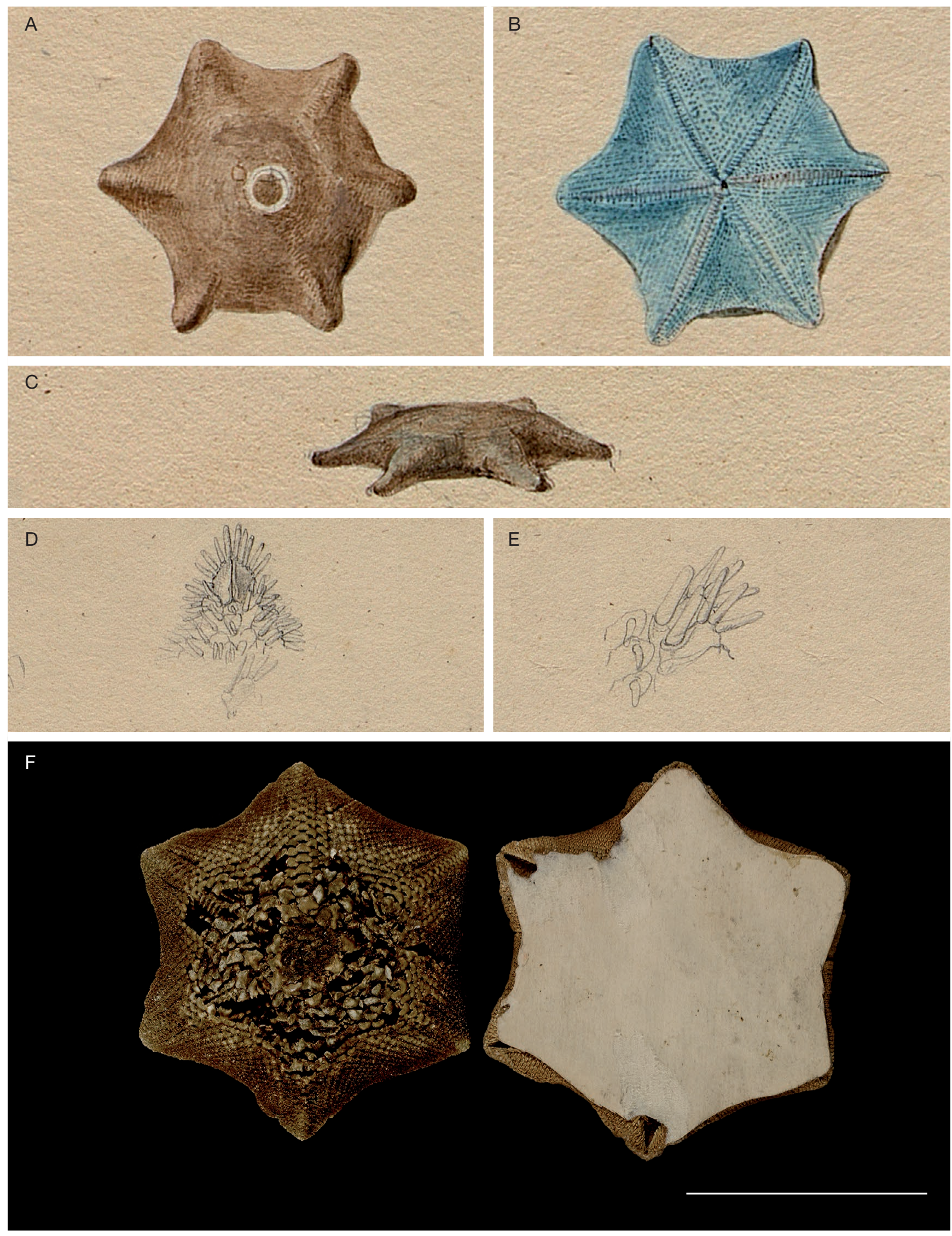

FIG. 5. - Asterias calcar var. hexagona Lamarck, 1816: A, B, abactinal (A) and actinal (B) surfaces; C, profile view; D, interradial arc; E, adambulacral spines; F, holotype of Meridiastra gunni (A-E, Lesueur collection ref. 74003, details, courtesy of MHNH; F, MNHN-IE-2014-508). Scale bar: 50 mm. 

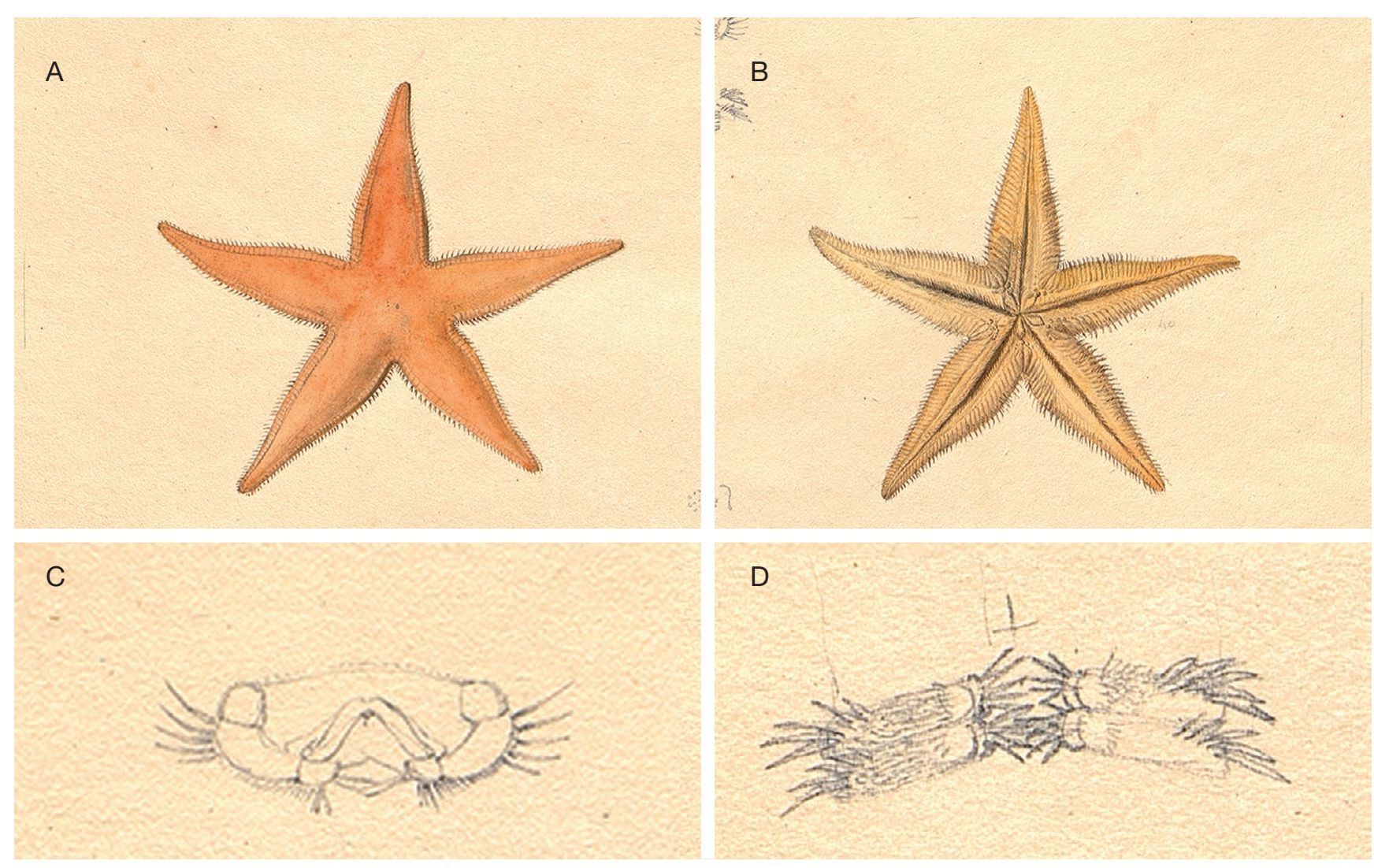

FIG. 6. - Asterias calcitrapa var. 1 Lamarck, 1816: A, B, abactinal (A) and actinal (B) surfaces; C, arm cross-section showing arrangement of skeletal plates; D, ambulacral armament and inferomarginal plates (Lesueur collection 74012, details, courtesy of MHNH).

calcitrapa Lamarck, 1816, Asterias

Asterias calcitrapa Lamarck, 1816: 563.

\section{REMARK}

Lamarck (1816) reported that two varieties of Asterias calcitrapa (varieties 1 and 2) were collected by Péron and Lesueur, presumably in the South Seas. While A. calcitrapa clearly belongs to the astropectinid family, the descriptions given by Lamarck were too vague to allow an identification and the name was considered a nomen dubium (Döderlein 1917: 183; Clark 1989: 254). However, several drawings of Lesueur represent two astropectinid species that are not uncommon in Australian waters, and we can reasonably suggest they could represent the two varieties of Lamarck's A. calcitrapa.

\section{calcitrapa var. 1 Lamarck, 1816, Asterias} (Fig. 6)

Asterias calcitrapa Lamarck, 1816: 563.

Astropecten calcitrapa - Clark 1989: 254.

CURRENT STATUS. - Asterias calcitrapa var. 1 is newly synonymized here with Bollonaster pectinatus (Sladen, 1883).
MATERIAL EXAMINED. - MHNH; Lesueur drawings collection; ref. 74012; Baudin expedition; Péron and Lesueur leg.

DiSTRIBUTION. - The species occurs in temperate water of southern Australia and around Tasmania.

\section{REMARKS}

Péron and Lesueur's material of $A$. calcitrapa var. 1 could not be found in the MNHN.

Lesueur detailed drawings of both arm cross section and arm actinal surface (Fig. 6C and D) allow to identify the species as Bollonaster pectinatus.

calcitrapa var. 2 Lamarck, 1816, Asterias (Fig. 7)

Asterias calcitrapa Lamarck, 1816: 563.

CURRENT STATUS. - Asterias calcitrapa var. 2 is newly synonymized here with Astropecten vappa Müller \& Troschel, 1843.

Material EXAMINED. - MHNH; Lesueur drawings collection; ref. 74011; Baudin expedition (1800-1804); Péron and Lesueur leg.

Distribution. - From west and north Australia up to Sri Lanka and South China sea. 

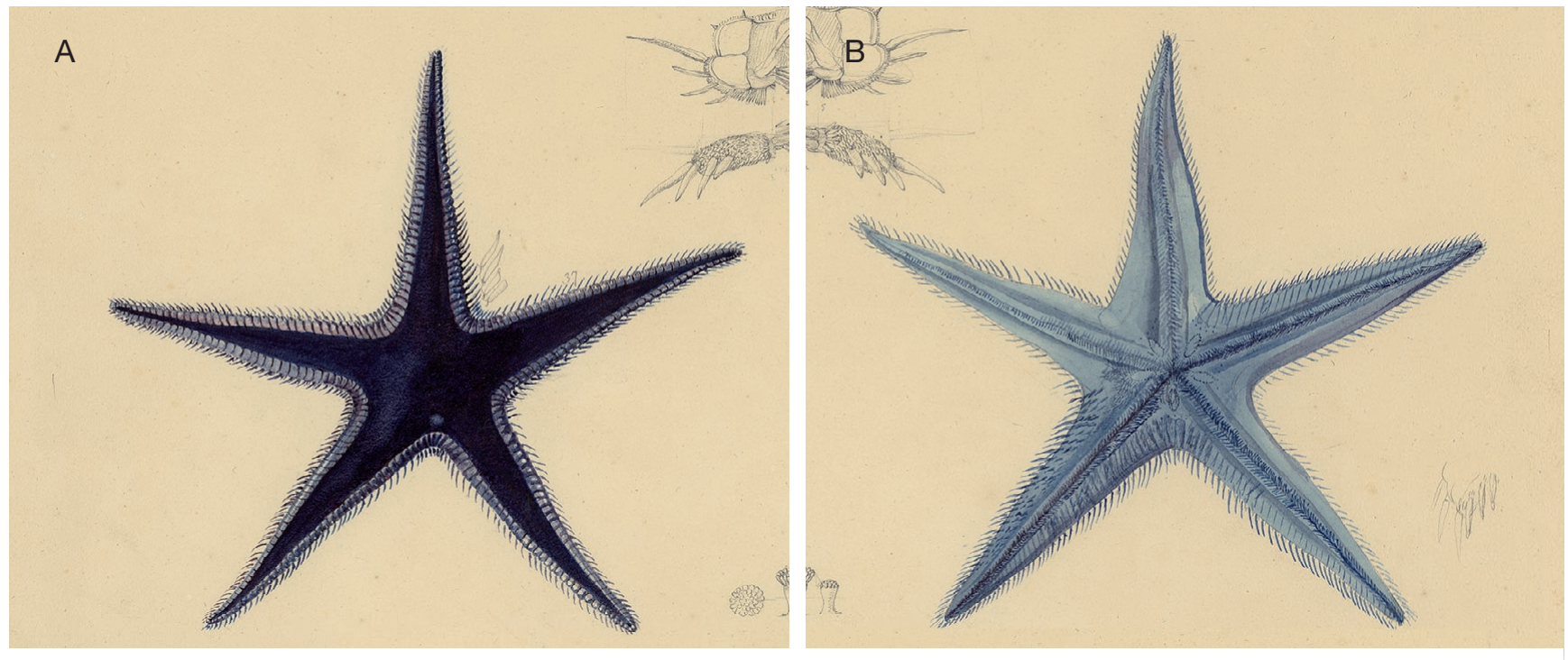

C
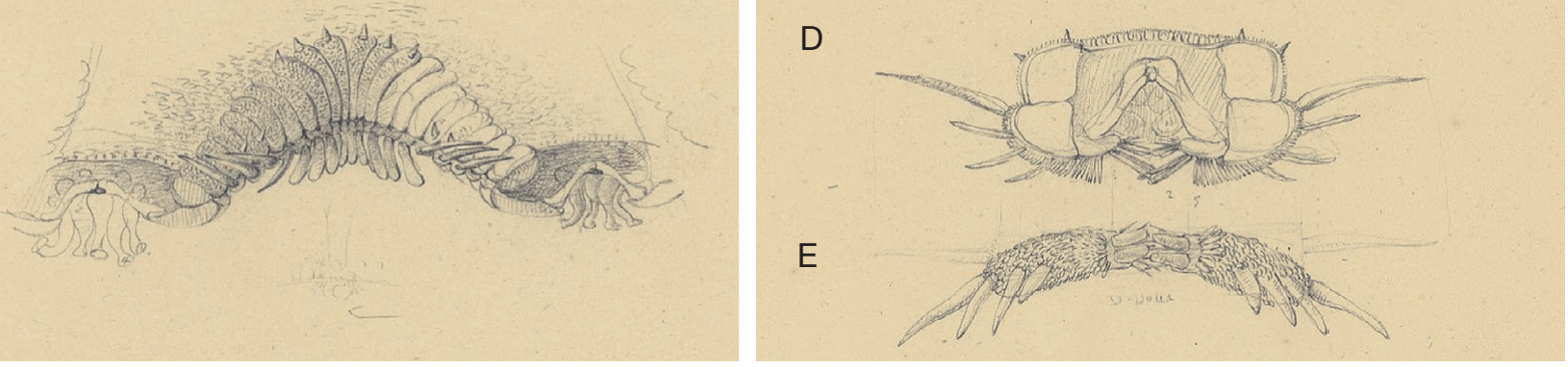

FIG. 7. - Asterias calcitrapa var. 2 Lamarck, 1816: A, B, abactinal (A) and actinal (B) surfaces; C, interradial marginal plates; D, arm cross-section showing the arrangement of skeletal plates; E, ambulacral armature and inferomarginal plates (Lesueur collection 74011, details, coutesy of MHNH).
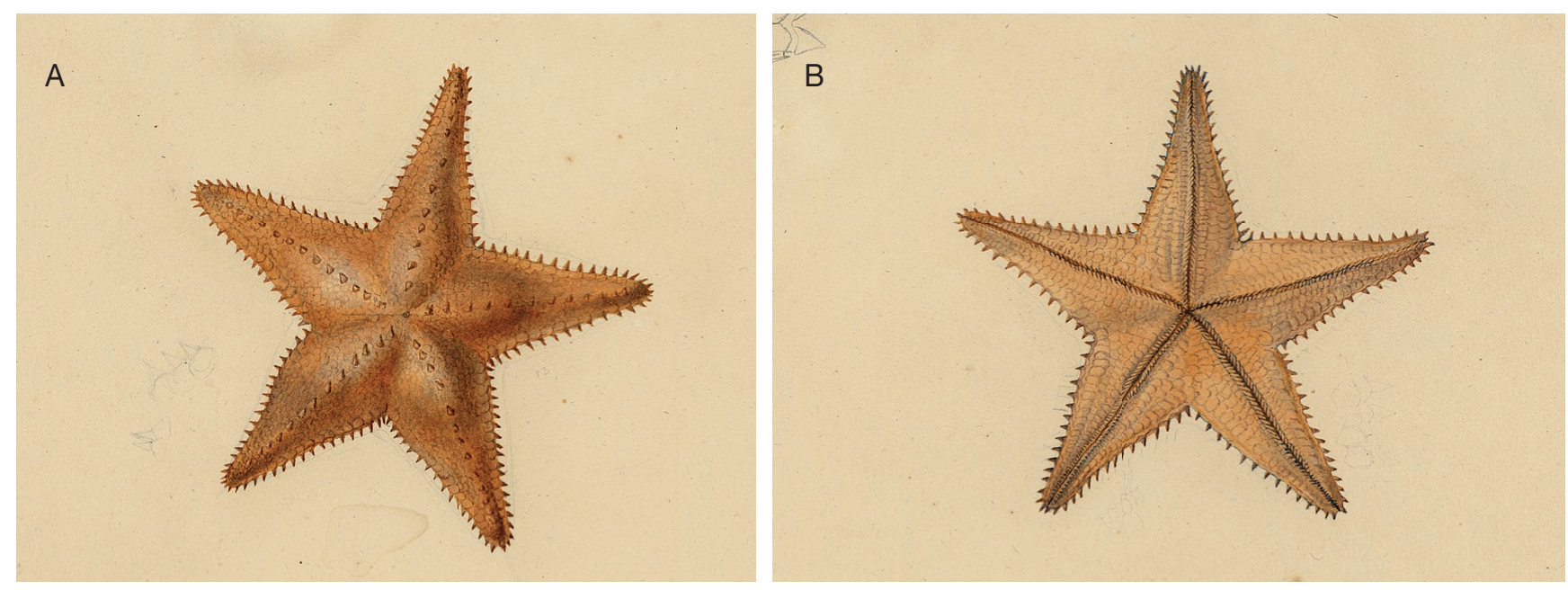

C

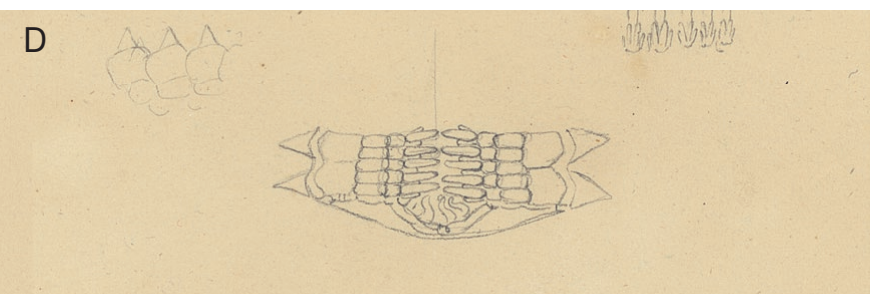

FIG. 8. - Asterias carinifera Lamarck, 1816: A, B, abactinal (A) and actinal (B) surfaces; C, profile view; D, ambulacral armament and actinolateral and inferomarginal plates (A-D, Lesueur collection 74041, details, courtesy of MHNH). 


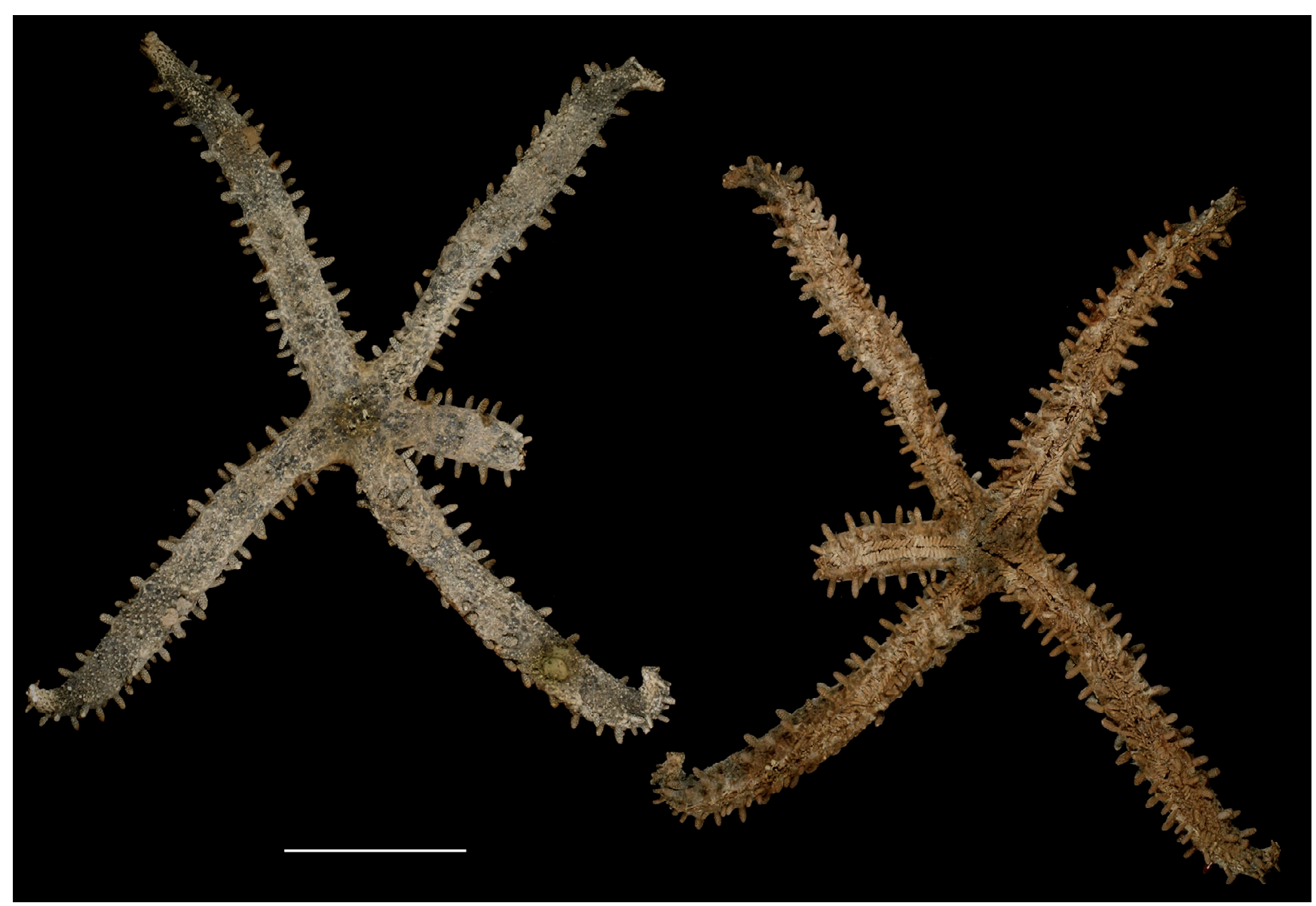

FIG. 9. - Asterias clavigera Lamarck, 1816: abactinal and actinal surfaces of a syntype (MNHN-IE-2014-71). Scale bar: 50 mm.

REMARK

Péron and Lesueur's material of $A$. calcitrapa var. 2 could not be found in the MNHN.

Lesueur detailed drawings of both arm cross section and arm actinal surface (Fig. 7C and D) allow to identify the species as Astropecten vappa.

\section{carinifera Lamarck, 1816, Asterias}

(Fig. 8)

Asterias carinifera Lamarck, 1816: 556.

Asteropsis carinifera - Clark 1993: 320.

CURRENT STATUS. - Asteropsis carinifera (Lamarck, 1816).

MATERIAL EXAMINED. - MHNH; Lesueur collection 74041; Baudin expedition (1800-1804); Péron and Lesueur leg.

Distribution. - Widely distributed in the tropical Indo-West Pacific.

\section{REMARK}

Lamarck's Latin diagnosis for Asterias carinifera is as follows: "angulis prorrectis; margine aculato; dorso carinis quinque aculatis muricato [angles well marked; margin spiny; carinated arms each with a row of prominent spines]". This definition clearly corresponds to adult individuals of $A$. carinifera (see further comment under the species Asterias punctata Lamarck, 1816). Péron and Lesueur's material of $A$. carinifera could not be found in the MNHN.

\section{clavigera Lamarck, 1816, Asterias}

(Fig. 9)

Asterias clavigera Lamarck, 1816: 562.

Mithrodia clavigera-Clark 1993: 324.

CURRENT STATUS. - Mithrodia clavigera (Lamarck, 1816).

Material EXAMINED. — Mauritius • MNHN-IE-2014-71: 2 syntypes; Baudin expedition (1800-1804); Péron and Lesueur leg.

Distribution. - Widely distributed in the tropical Indo-West Pacific; a few records in tropical Atlantic (Central America).

\section{REMARK}

Though the species was collected by Péron and Lesueur during the Baudin expedition, no drawings of this species could be found in the Lesueur collection at Le Havre Museum. 

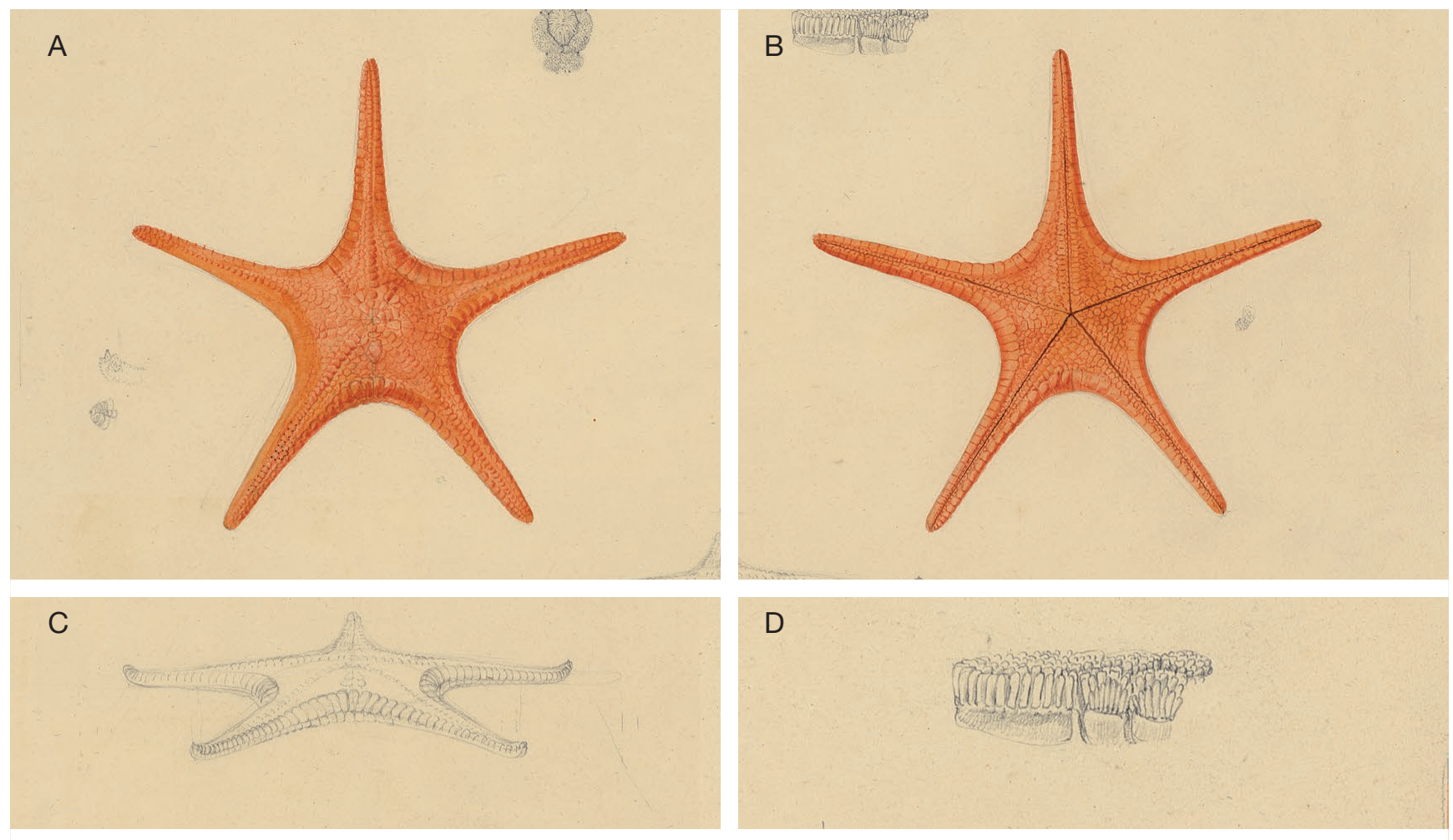

$\mathrm{E}$
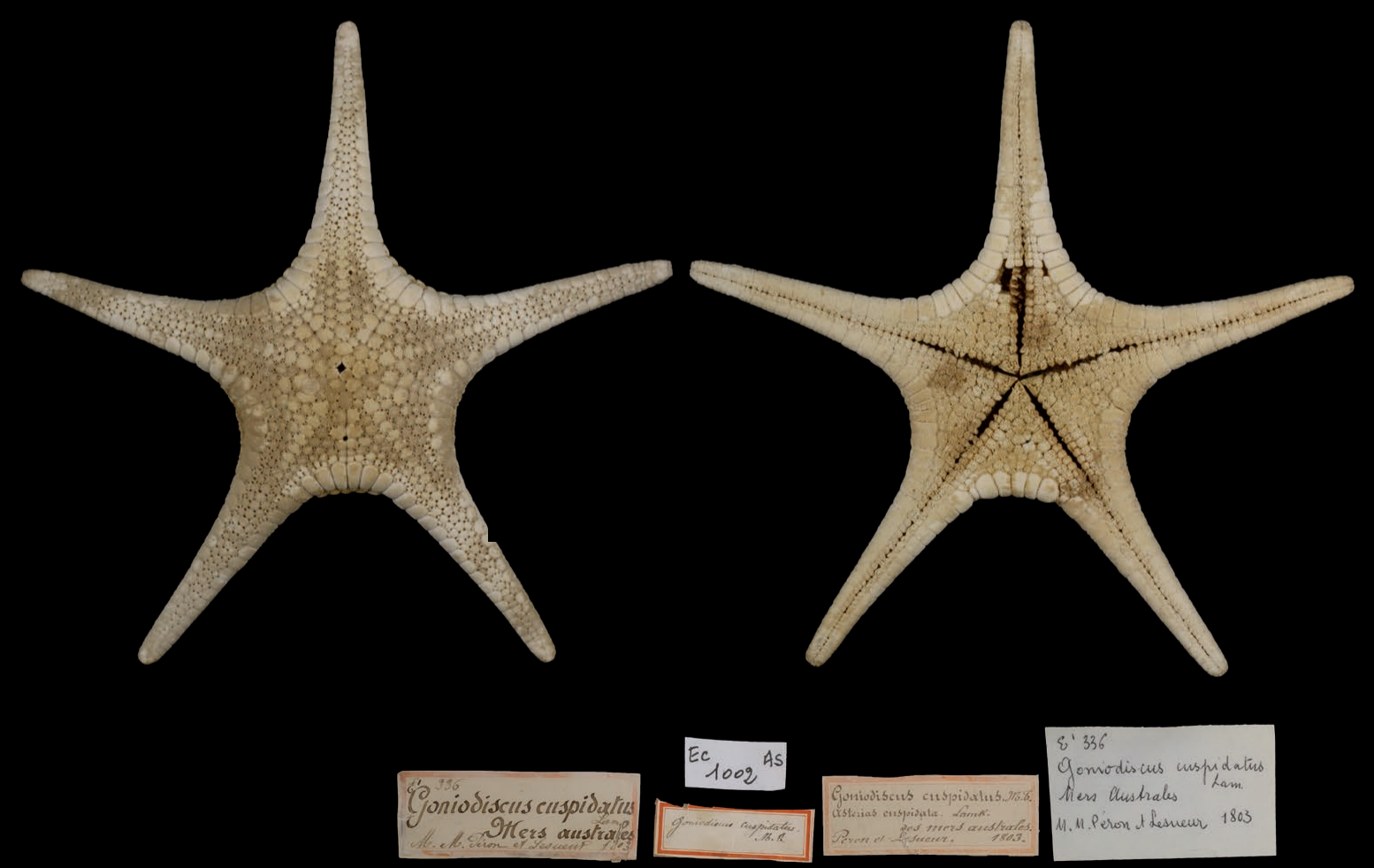

FIG. 10. - Asterias cuspidata Lamarck, 1816: A, B, abactinal (A) and actinal (B) surfaces; C, profile view; D, interradial arc and ambulacral armament; E, holotype of the species (A-D, MHNH, Lesueur collection 74022, details, courtesy of MHNH; E, MNHN-IE-2014-3). Scale bar: E, $50 \mathrm{~mm}$. 
cuspidata Lamarck, 1816, Asterias

(Fig. 10)

Asterias cuspidata Lamarck, 1816: 553.

Goniaster tessellatus - Clark 1993: 256.

CURRENT STATUS. - Asterias cuspidata is transferred here to the genus Mediaster Stimpson, 1857 as Mediaster cuspidatus (Lamarck, 1816) n. comb.

MATERIAL EXAMINED. — South Seas • MNHN-IE-2014-3; holotype; Baudin expedition (1800-1804); Péron and Lesueur leg. $\bullet$ MHNH; Lesueur drawings collection; ref. 74022; Baudin expedition.

Distribution. - South Seas. (Note that the related species Mediaster australiensis H. L. Clark, 1916 was found in Australia [Victoria, Bass Strait] and Tasmania.)

REMARKS

Both Lesueur's drawings and the original holotype label attest that Lamarck's Asterias cuspidata originates from the South Seas. Surprisingly A. cuspidata was considered a synonym of the Atlantic Asterias tessellata Lamarck, 1816, which is more than unlikely both geographically and morphologically. Lamarck himself reported that $A$. cuspidata "differs from Asterias tessellata because its angles continue with long spikes resembling straight horns or rays [On l'en distingue par ses angles prolongés en longues pointes comme des cornes droites ou des rayons]". In fact, the cuspidata-tessellata problem results from the confusion between Asterias cuspidata Lamarck and Goniaster cuspidatus Gray, 1840 the latter being indeed synonym of Lamarck's Asterias tessellata.

From its overall morphological features, Asterias cuspidata belongs to the Goniasteridae, and its closest genus is Mediaster Stimpson, 1857. Indeed $A$. cuspidata is clearly related to the Australian species Mediaster australiensis H. L. Clark, 1916 (Clark 1916: 30-31, pl. 9), a species known from Bass Strait and around Tasmania. Some differences occur, however, such as the general appearance (the disc area of $A$. cuspidata is narrower giving it a more stellate form) or the occurrence in A. cuspidata of a row of enlarged carinal plates. Therefore, awaiting additional information of M. australiensis variability, it sounds better to keep the two species separate.

\section{cylindrica Lamarck, 1816, Asterias}

(Fig. 11)

Asterias cylindrica Lamarck, 1816: 567.

Dactylosaster cylindricus - Clark 1993: 329.

CuRRENT STATUS. - Dactylosaster cylindricus (Lamarck, 1816).

MATERIAL EXAMINED. — Mauritius • MNHN-IE-2014-471; holotype; Baudin expedition (1800-1804); Péron and Lesueur leg. • MHNH: Lesueur drawings collection; ref. 74014; Baudin expedition.

Distribution. - The species is found in the tropical Indo-West Pacific.

\section{REMARK}

According to Perrier $(1869 ; 1875)$, the two individuals collected by Péron and Lesueur in Mauritius in 1803 belong to two species that differ, among other characters, by the presence (D. cylindricus) or absence of enlarged granules on the central part of abactinal plates. He created the species Ophidiaster purpureus Perrier, 1869 (see further under that species) to accommodate the second individual.

\section{decanus Müller \& Troschel, 1843, Echinaster}

(Fig. 12)

Echinaster decanus Müller \& Troschel, 1843: 114.

Plectaster decanus - Clark 1996: 244.

Current Status. - Plectaster decanus (Müller \& Troschel, 1843).

MATERIAL EXAMINED. - MHNH: Lesueur drawings collection, ref. 74053 (Baudin expedition, Péron and Lesueur leg.).

DisTRIBUTION. - The species is distributed thoughout the south coast of Australia up to Newcastle in New South Wales, and in Tasmania.

\section{REMARK}

Péron and Lesueur's material of Echinaster decanus could not be found in the MNHN.

\section{discoidea Lamarck, 1816, Asterias}

(Fig. 13)

Asterias discoidea Lamarck, 1816: 554.

Culcita schmideliana - Clark 1993: 298.

CURRENT STATUs. - Culcita schmideliana (Bruzelius, 1805).

MATERIAL EXAMINED. - MHNH; Lesueur drawings collection; ref. 74006; Baudin expedition; Péron and Lesueur leg.

DiSTRIBUTION. - Culcita schmideliana commonly occurs in the Indian ocean, along the coast of Africa and the NW coast of Australia.

\section{REMARK}

Lamarck's type material could not be found in the MNHN.

echinophora Lamarck, 1816, Asterias

(Fig. 14)

Asterias echinophora Lamarck, 1816: 560.

Echinaster (Othilia) echinophorus - Clark \& Downey 1992: 367.

CURRENT STATUS. - Echinaster (Othilia) echinophorus (Lamarck, 1816).

Material eXamined. - North America • MNHN-IE-2014-72; 4 syntypes; coast of Virginia; Lamarck collection.

Distribution. - From Florida to NE Brazil.

REMARK

Lamarck's type locality is doubtful and the syntypes most probably came from Brazil (Clark \& Downey 1992: 370). 

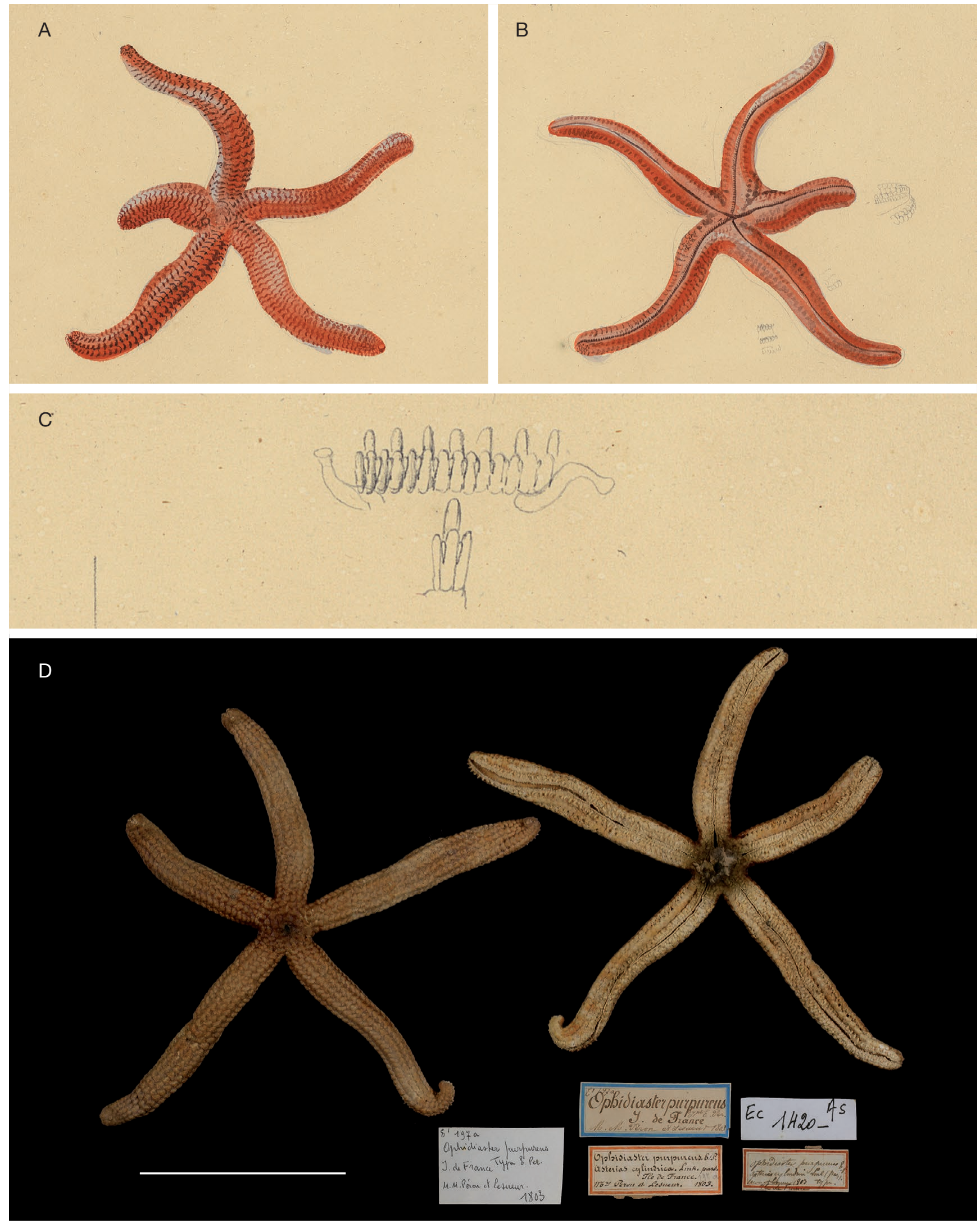

FIG. 11. - Asterias cylindrica Lamarck, 1816: A, B, abactinal (A) and actinal (B) surfaces; C, adambulacral armament; D, holotype of the species (A-C, MHNH, Lesueur collection 74014, details, courtesy of MHNH; D, MNHN-IE-2014-471). The accompanying labels do not relate to the pictured specimen. The holotype of $O$. purpureus Perrier, 1869 is shown in Figure 32 . Scale bar: $50 \mathrm{~mm}$. 

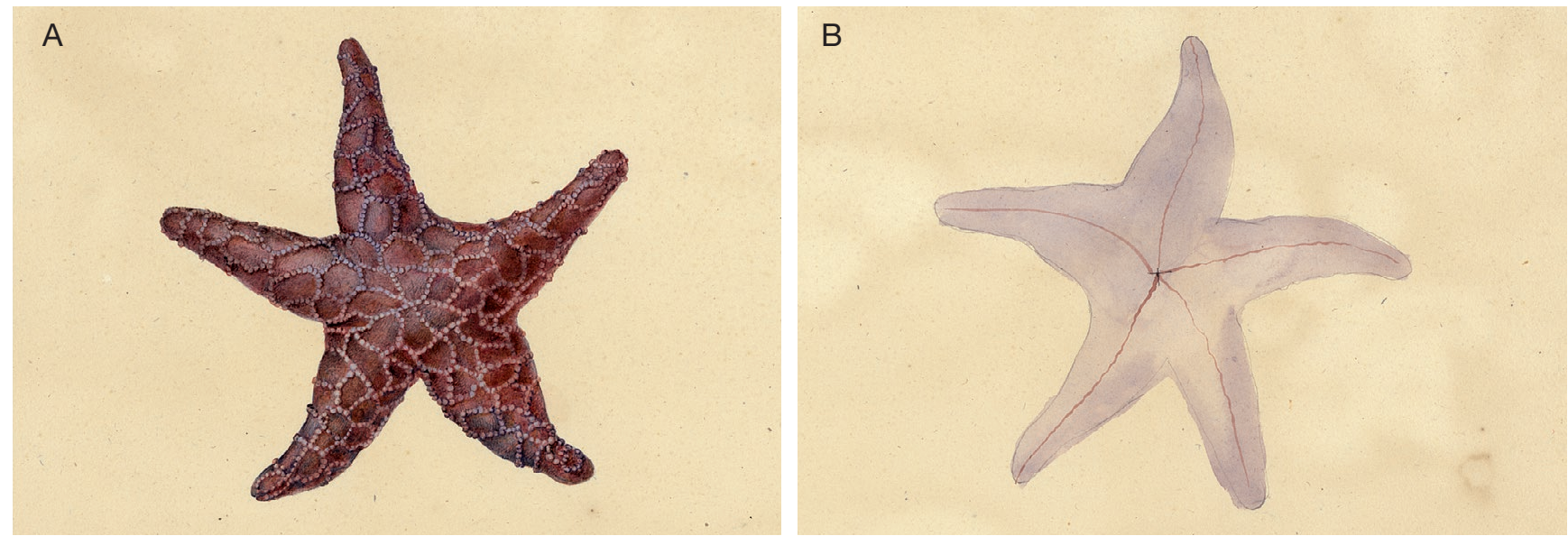

FIG. 12. - Echinaster decanus Müller \& Troschel, 1843: A, B, abactinal (A) and actinal (B) surfaces (MHNH, Lesueur collection 74053, details, courtesy of MHNH).

A

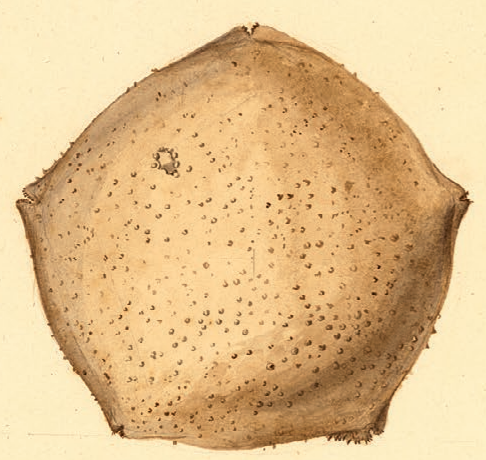

B

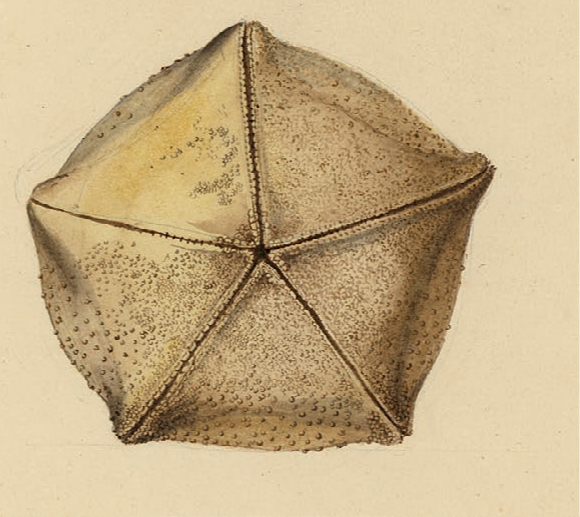

C

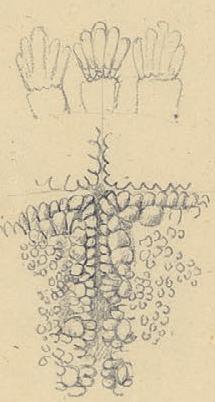

FIG. 13. - Asterias discoidea Lamarck, 1816: A, B, abactinal (A) and actinal (B) surfaces; C, adambulacral spines (above), interradial arcs (below) (MHNH, Lesueur collection 74006 , details, courtesy of $\mathrm{MHNH}$ ).

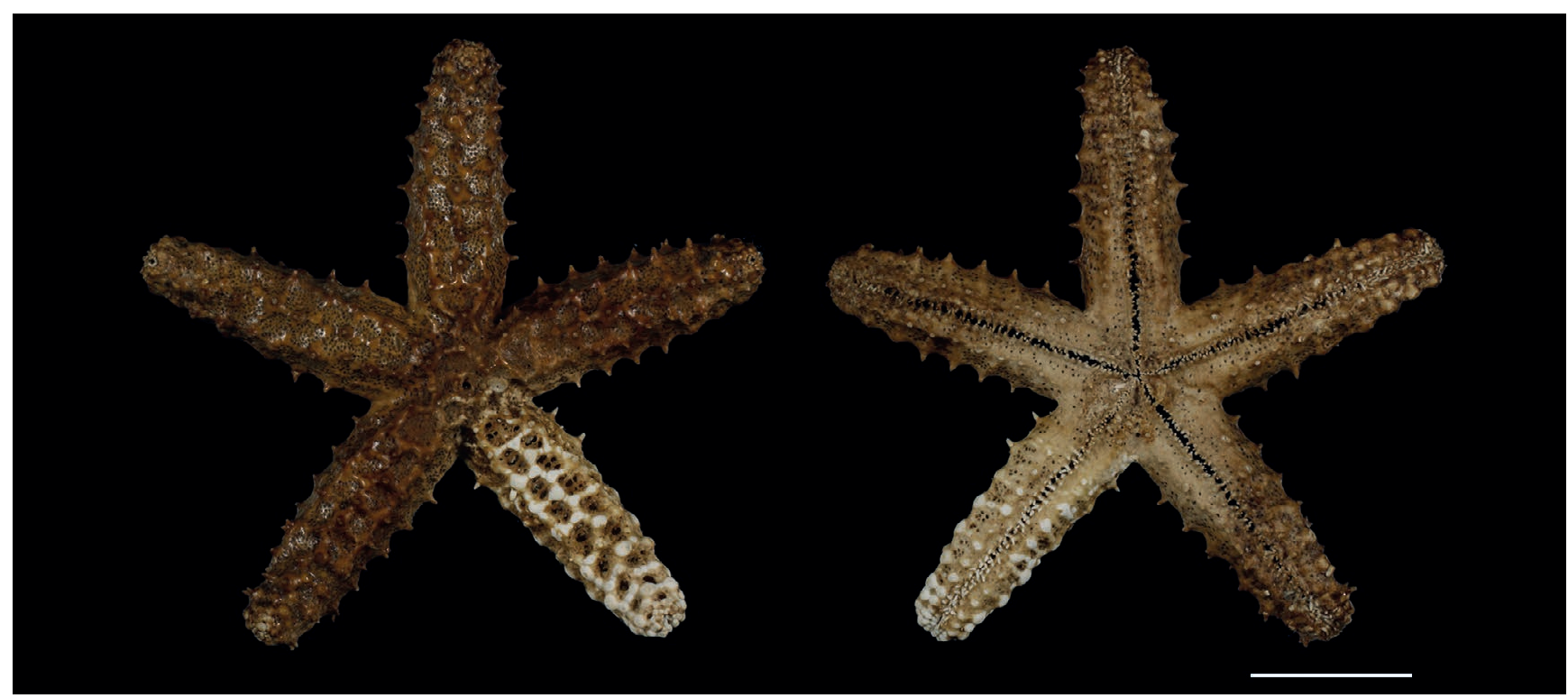

FIG. 14. - Asterias echinophora Lamarck, 1816: abactinal and actinal surfaces of a syntype of the species (MNHN-IE-2014-72). Scale bar: 20 mm. 
A
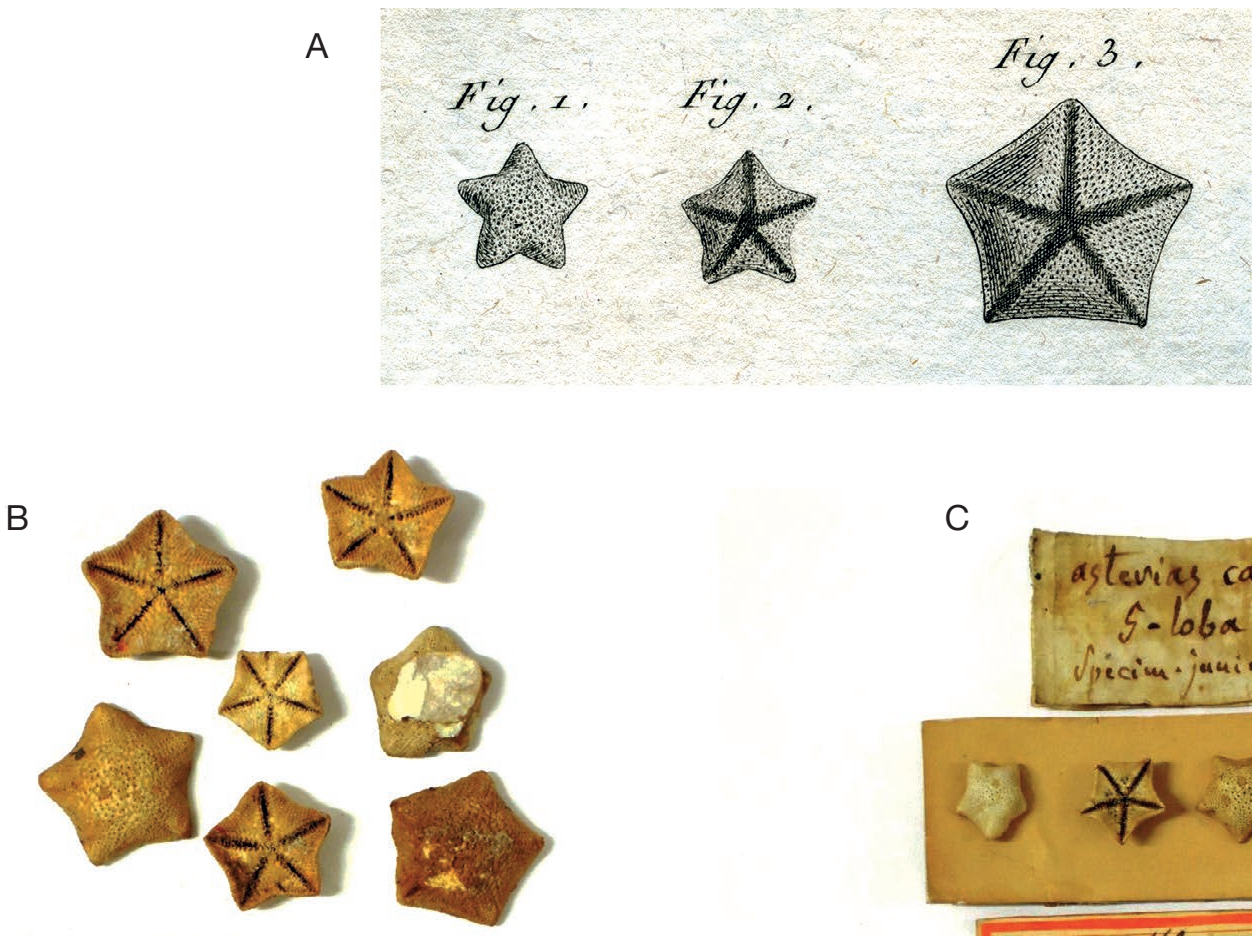

C

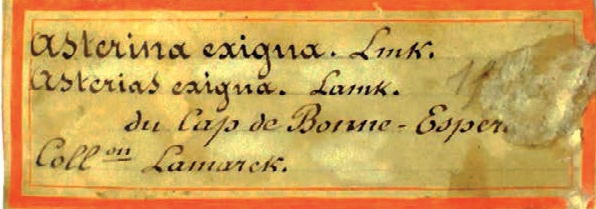

Usterina 162 cegilarib. Venille,jome

obsteriab calcar, var a fls. Gypos.

Trelle Hballaride.

176. 216. YS. 1803.
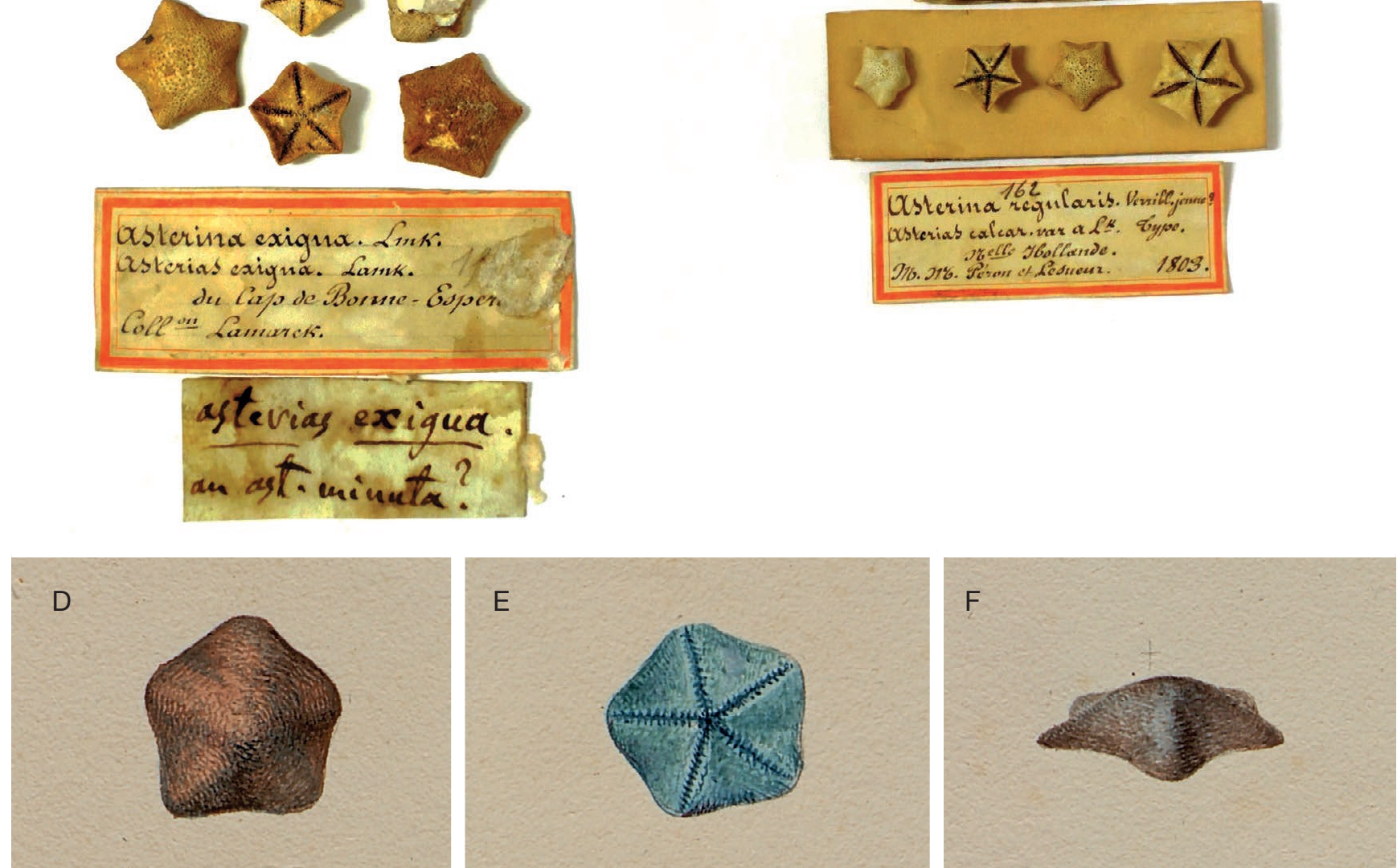

FIG. 15. - Asterias exigua Lamarck, 1816: A, drawings of Bruguière (1791); B, type specimens of Asterias exigua. C, type specimens of Asterias calcar var. quinqueangula, D-F, Lesueur's drawings of Asterias exigua: abactinal (D) and actinal (E) surfaces, and profile view (F) (B, MNHN-IE-2014-526; C, MNHN-IE-2014-30; D-F, MHNH, Lesueur collection 74004, details, courtesy of MHNH).

exigua Lamarck, 1816, Asterias

(Fig. 15)

Asterias exigua Lamarck, 1816: 554.

Asterias calcar var. quinqueangula Lamarck, 1816: 557.

Parvulastra exigua - O'Loughlin \& Waters 2004: 225.

CurRent status. - Parvulastra exigua (Lamarck, 1816).
Material eXAmined. - South Africa • MNHN-IE-2014-526; Asterias exigua; 6 syntypes; Cape of Good, Hope Baudin expedition (1800-1804); Péron and Lesueur leg.

Australia • MNHN-IE-2014-30; Asterias calcar var. quinqueangula; 4 syntypes; Baudin expedition (1800-1804); King George Sound, Albany, Péron and Lesueur leg. $\bullet$ MHNH; Lesueur drawings collection, ref. 74004; Baudin expedition.

DistRiBution. - From the southernmost part of Africa to the south of Australia and Tasmania. 

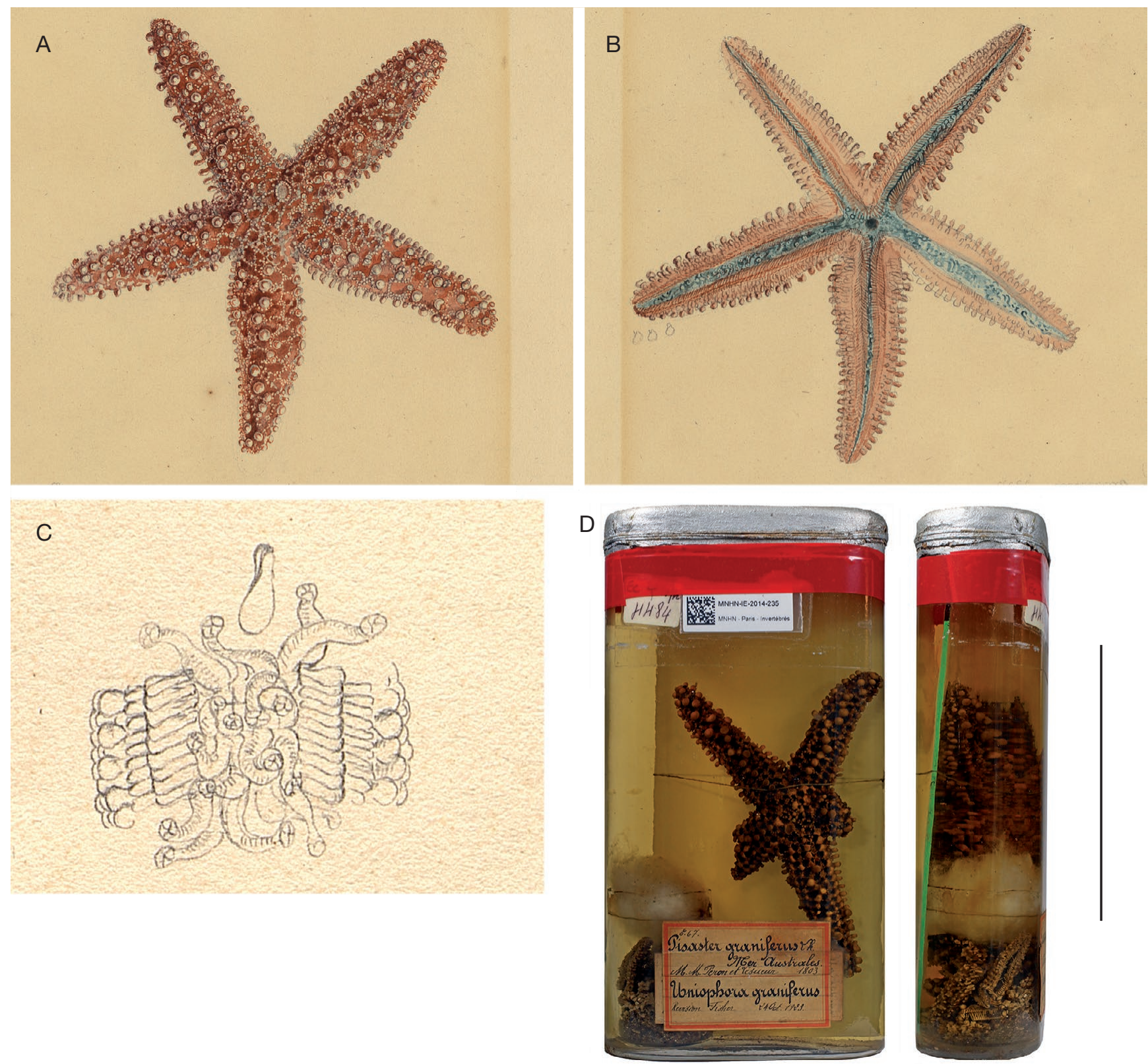

FIG. 16. - Asterias granifera Lamarck, 1816: A, B, abactinal (A) and actinal (B) surfaces; C, arm showing tube feet and adambulacral spines; D, holotype of the species (A-C, MHNH, Lesueur collection 74046 and 74047, details, courtesy of MHNH; D, MNHN-IE-2014-235).

\section{REMARKS}

According to Lamarck (1816) Asterias exigua came from American seas and was the smallest known species of asteroid. As far as size is concerned, he is almost correct. Yet $A$. exigua does not occur in the Atlantic but in the south of Africa and Australia as well as in Tasmania. Indeed the type specimens of A. exigua were collected in South Africa by Péron and Lesueur in 1804 (Fig. 15B). Individuals of a most likely similar species had been obtained early in 1803 by the same collectors in SE Australia (King George Sound, Albany). The latter were identified Asterina calcar var. quinqueangula by Lamarck, who added on a label that they should be considered juvenile individuals ("specimen junius") (Fig. 15C-F). Comparing the type specimens of the two Lamarckian species (and to the drawings of Bruguière [1791] to which Lamarck refered, Figure 15A), it is highly likely they are conspecific.

Due to incorrect information (types of Asterias exigua presumed loss), Dartnall (1971) designated a neotype for the species. The latter originated from False Bay (South Africa) and is in the Tasmanian Museum, Hobart (ref. TM H508).

\section{granifera Lamarck, 1816, Asterias}

(Fig. 16)

Asterias granifera Lamarck, 1816: 560. 

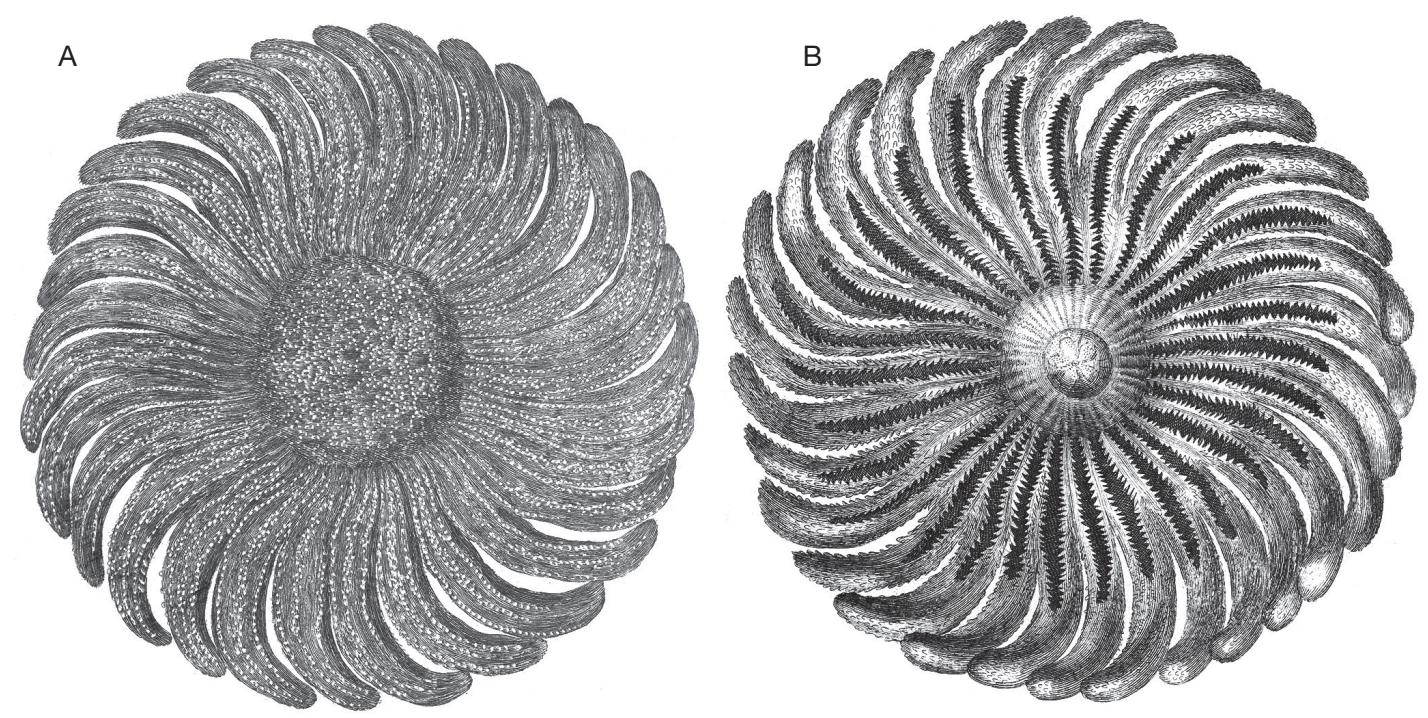

FIG. 17. - Heliaster helianthus Lamarck, 1816: Bruguière's (1791) drawings of the abactinal (A) and actinal (B) surfaces of the holotype.
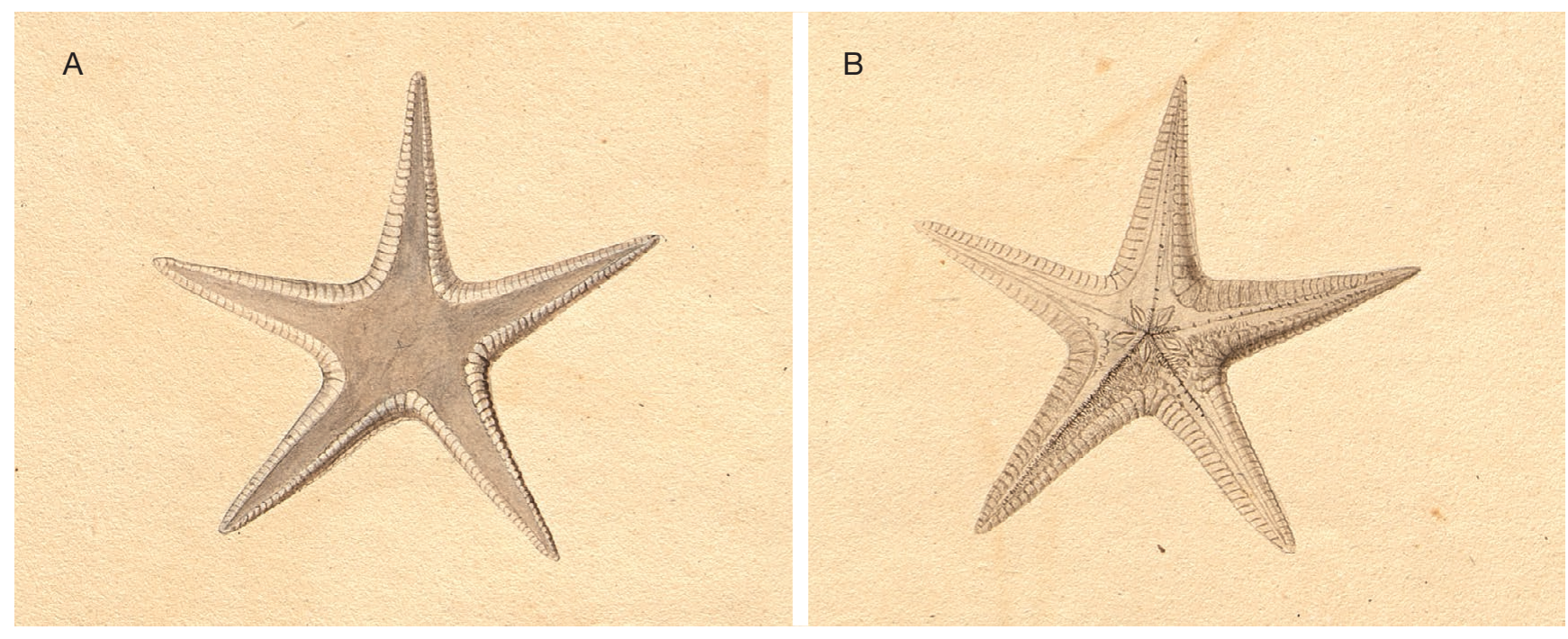

FIG. 18. - Archaster hesperus Müller \& Troschel, 1840: A, B, abactinal (A) and actinal (B) surfaces (MHNH, Lesueur collection 74010, details, courtesy of MHNH).

Uniophora granifera - Clark in Clark \& Mah 2001: 305.

CURRENT STATUS. - Uniophora granifera (Lamarck, 1816).

Material eXamined. - South Seas - MNHN-IE-2014-235; holotype; Baudin expedition (1800-1804); Péron and Lesueur leg.

- MHNH; Lesueur drawings collection; ref. 74046 and 74047; Baudin expedition.

Distribution. - South coast of Australia, Tasmania.

\section{helianthus Lamarck, 1816, Asterias}

(Fig. 17)

Asterias helianthus Lamarck, 1816: 558.

Heliaster helianthus - Clark in Clark \& Mah 2001: 307.
CURRENT STATUS. - Heliaster helianthus (Lamarck, 1816).

REMARK

Lamarck only refered to Bruguière's (1791: pl. 108-109) drawings when describing the species. He gave no localities though one could expect the drawn individual came from Chilean coast. Bruguière's material could not be found in the MNHN.

\section{hesperus Müller \& Troschel, 1840, Archaster}

(Fig. 18)

Archaster hesperus Müller \& Troschel, 1840: 104.

Craspidaster hesperus - Clark 1989: 274.

Current status. — Craspidaster hesperus (Müller \& Troschel, 1840). 

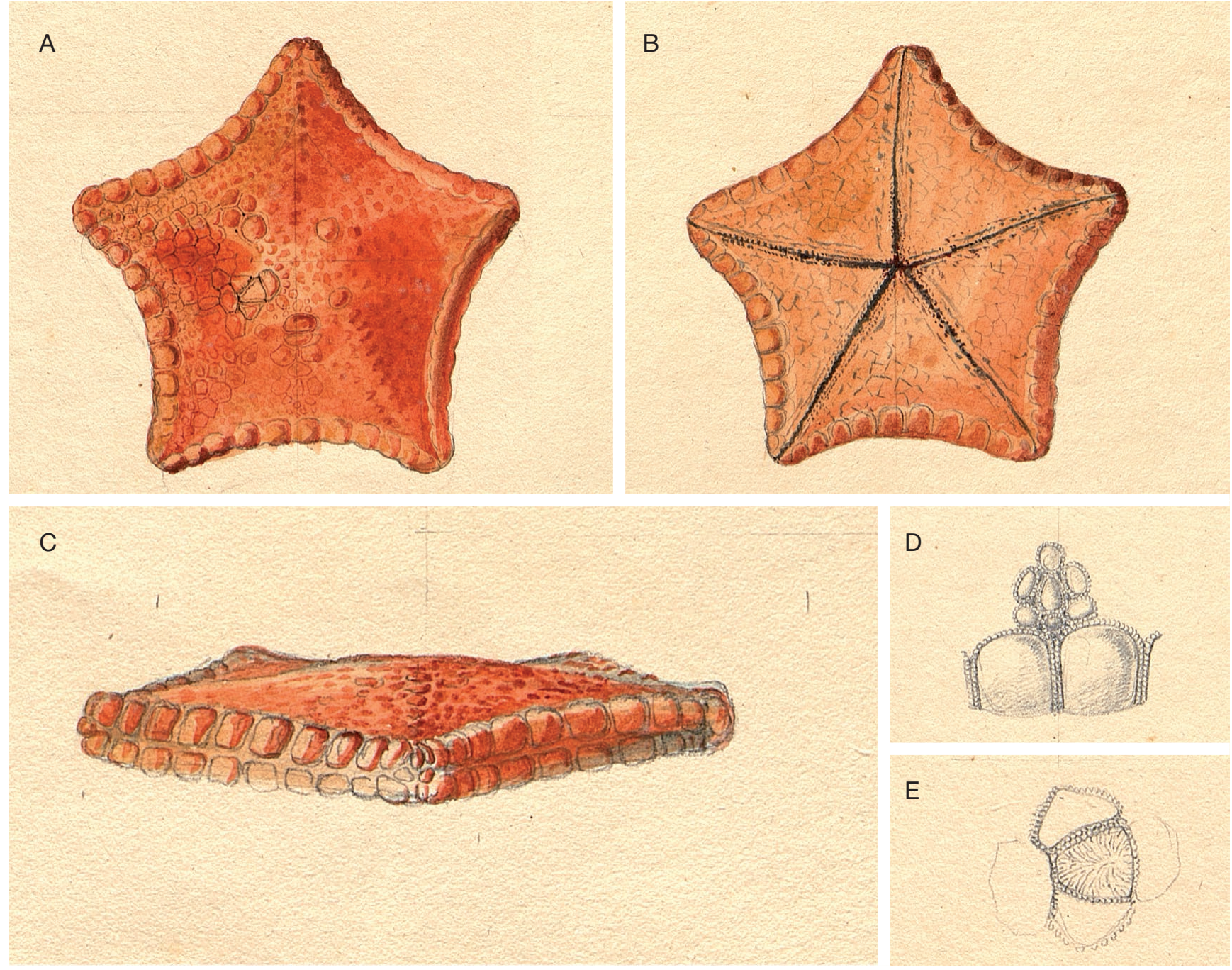

FiG. 19. - Astrogonium magnificum Müller \& Troschel, 1842: A, B, abactinal (A) and actinal (B) surfaces; C, profile view; D, superomarginal and abactinal plates; E, madreporite and disc abactinal plates (MHNH, Lesueur collection 74056, details, courtesy of MHNH).

Material EXAMINED. - Timor • MNHN-IE-2017-560; 2 individuals; Baudin expedition (1800-1804); supposedly from Timor; Péron and Lesueur leg. $\bullet \mathrm{MHNH}$ : Lesueur drawings collection, ref. 74010; Baudin expedition.

Distribution. - Indonasia, Bay of Bengal, Singapore, Philippines, South China Sea.

\section{magnificum Müller \& Troschel, 1842, Astrogonium}

(Fig. 19)

Astrogonium magnificum Müller \& Troschel, 1842: 53.

Tosia magnifica-Clark 1993: 289.

Current status. - Tosia magnifica (Müller \& Troschel, 1842).

Material EXAMined. - MHNH; Lesueur drawings collection; ref. 74056; Baudin expedition, Péron and Lesueur leg.

Distribution. - South of Australia and Tasmania.

\section{REMARK}

Péron and Lesueur's material could not be found in the MNHN.

milleporella Lamarck, 1816, Asterias

(Fig. 20)

Asterias milleporella Lamarck, 1816: 564.

Fromia milleporella - Clark 1993: 332.

CURRENT STATUS. - Fromia milleporella (Lamarck, 1816).

MATERIAL EXAMINED. - South Seas • MNHN-IE-2014-57, MNHNIE-2013-4376: 2 syntypes, Baudin expedition (1800-1804); Péron and Lesueur leg. $\bullet$ MHNH; Lesueur drawings collection; ref. 74016; Baudin expedition (1800-1804).

DisTRIBUTION. - The species commonly occurs in the tropical Indo-West Pacific. It is not present in European seas contrary to Lamarck's assumption. 

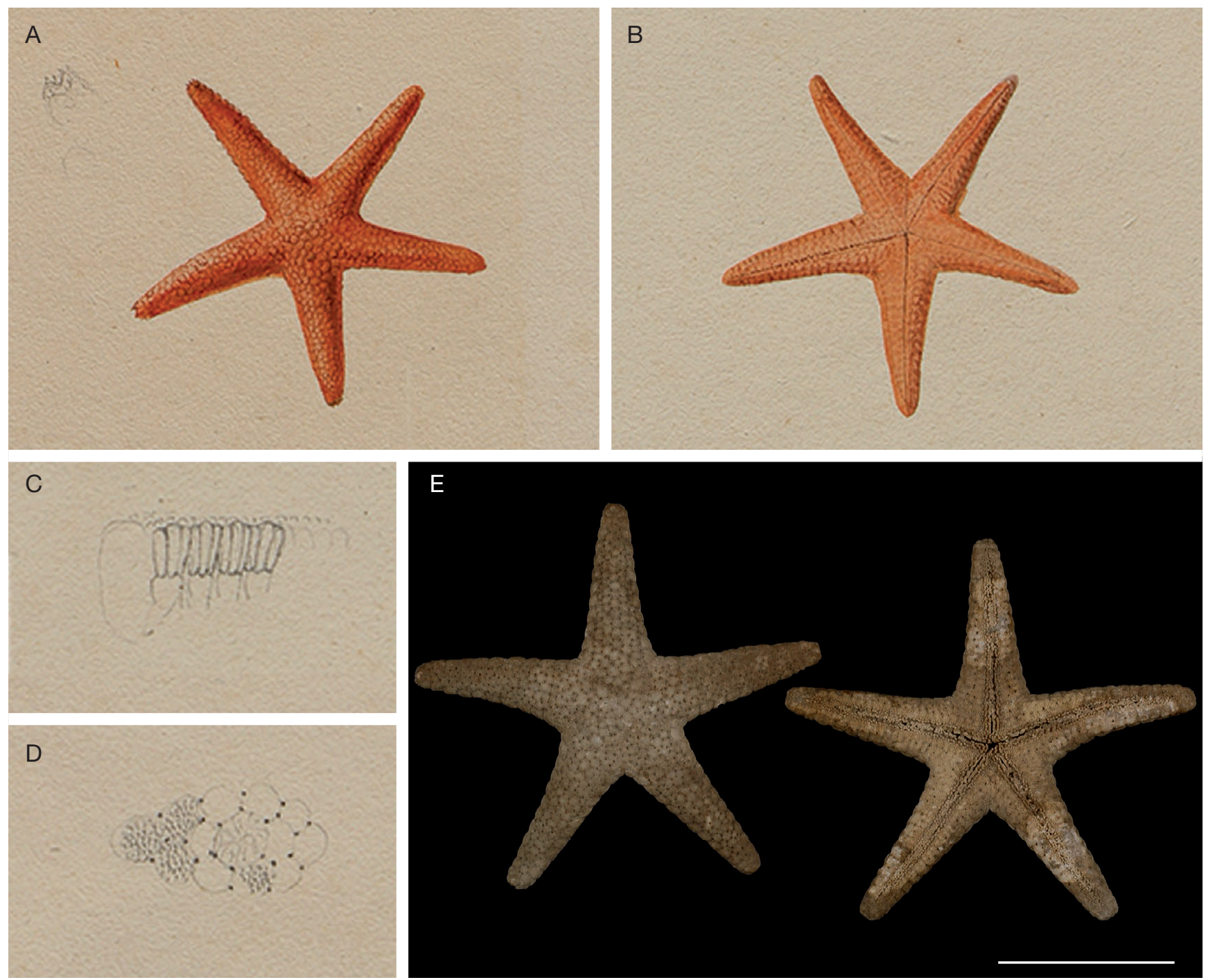

FiG. 20. - Asterias milleporella Lamarck, 1816: A, B, abactinal and actinal surfaces; C, furrow spines; D, madreporite and disc abactinal plates; E, syntype of the species (A-D, MHNH, Lesueur collection 74016, details, courtesy of MHNH; E, MNHN-IE-2014-57). Scale bar: 20 mm.

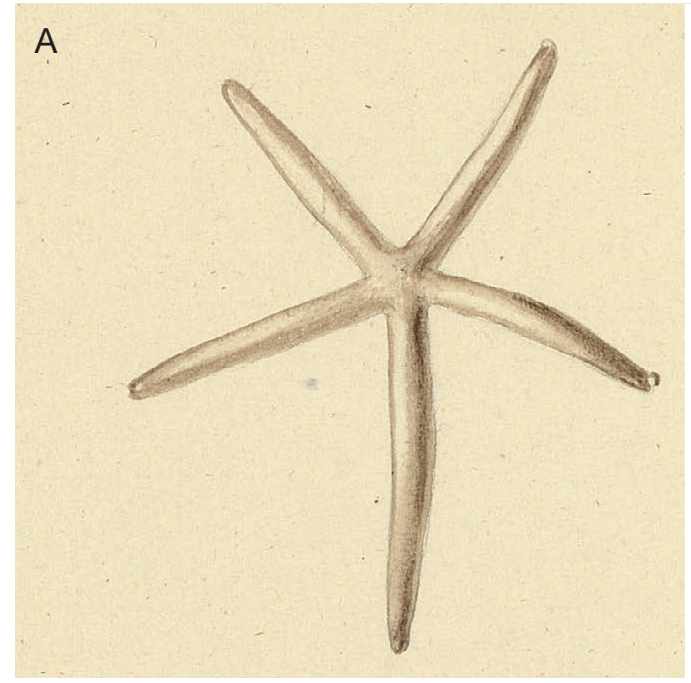

B

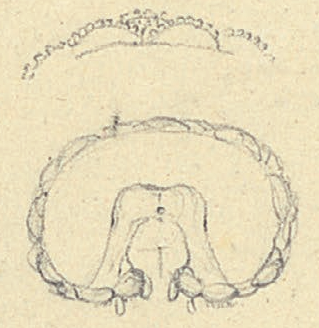

FIG. 21. - Asterias multifora Lamarck, 1816: A, abactinal surface; B, arm cross-section showing the arrangement of skeletal plates; C, adambulacral and actinolateral granules and plates (MHNH, Lesueur collection 74019, details, courtesy of MHNH). 

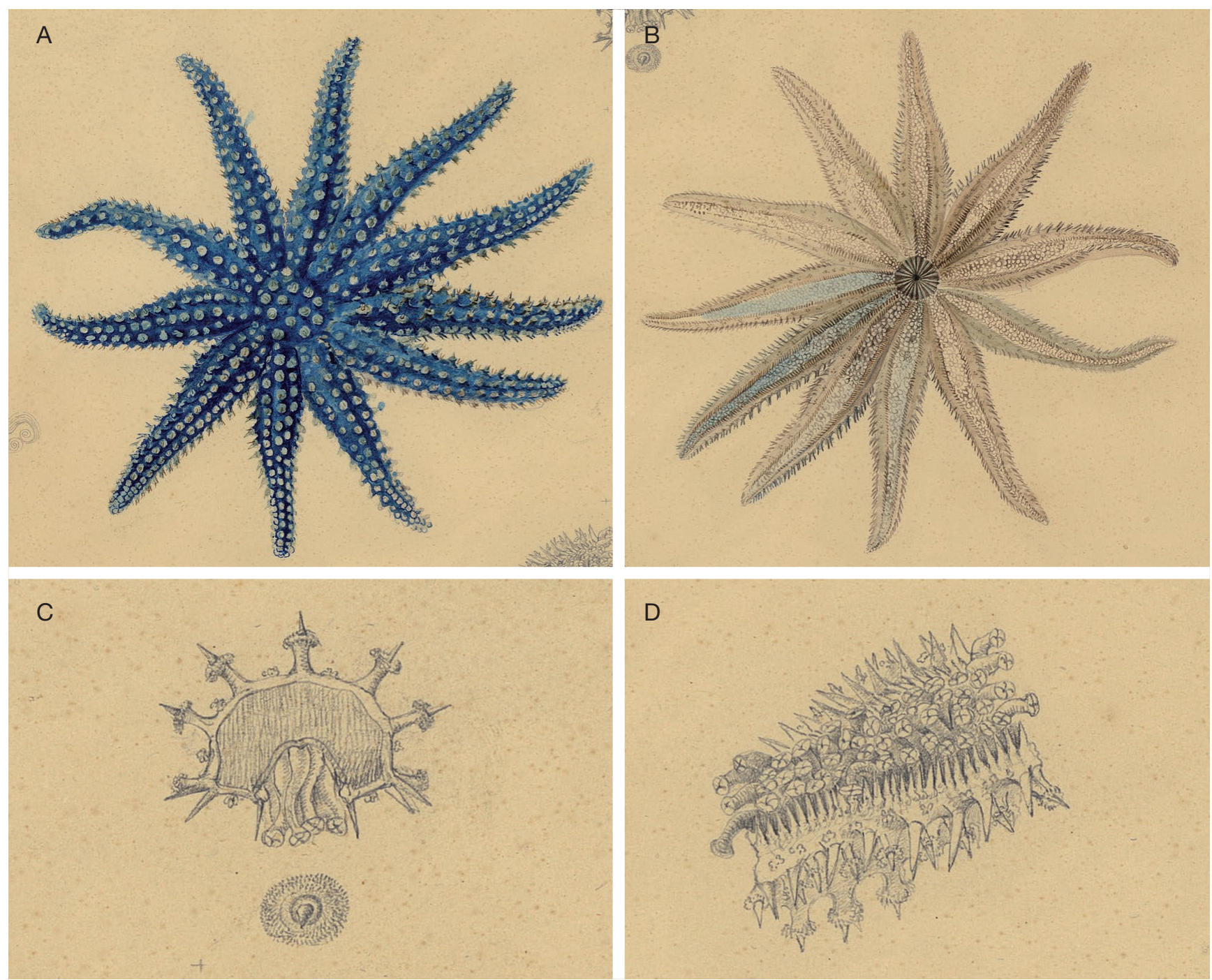

FIG. 22. - Coscinaterias muricata Verrill, 1867: A, B, abactinal (A) and actinal (B) surfaces; C, arm cross-section showing enlarged abactinal spines surronded by rings of crossed pedicellariae, below: upper view of such a spine and ring; $\mathbf{C}$, actinal side of an arm section showing tube feet and adambulacral and inferomarginal spines (MHNH, Lesueur collection 74036, details, courtesy of $\mathrm{MHNH})$.

multifora Lamarck, 1816, Asterias

(Fig. 21)

Asterias multifora Lamarck, 1816: 565.

Linckia multifora - Clark 1993: 339.

CURRENT STATUS. — Linckia multifora (Lamarck, 1816).

MATERIAL EXAMINED. - MHNH; Lesueur drawings collection; ref. 74019; Baudin expedition; Péron and Lesueur leg.

Distribution. - The species commonly occurs in the whole Indo-West Pacific. It does not occur in European seas contrary to Lamarck's assumption.

\section{REMARK}

Lamarck's type material could not be found in MNHN.

\section{muricata Verrill, 1867, Coscinasterias}

(Fig. 22)

Coscinasterias muricata Verrill, 1867: 249. - Clark in Clark \& Mah 2001: 270.

Current status. - Coscinasterias muricata Verrill, 1867.

MATERIAL EXAMINED. - MHNH; Lesueur drawings collection; ref. 74036; Baudin expedition (1800-1804); Péron and Lesueur leg.

Distribution. - Temperate Australia, Tasmania, New Zealand.

REMARK

Péron and Lesueur's material could not be found in the MNHN. 

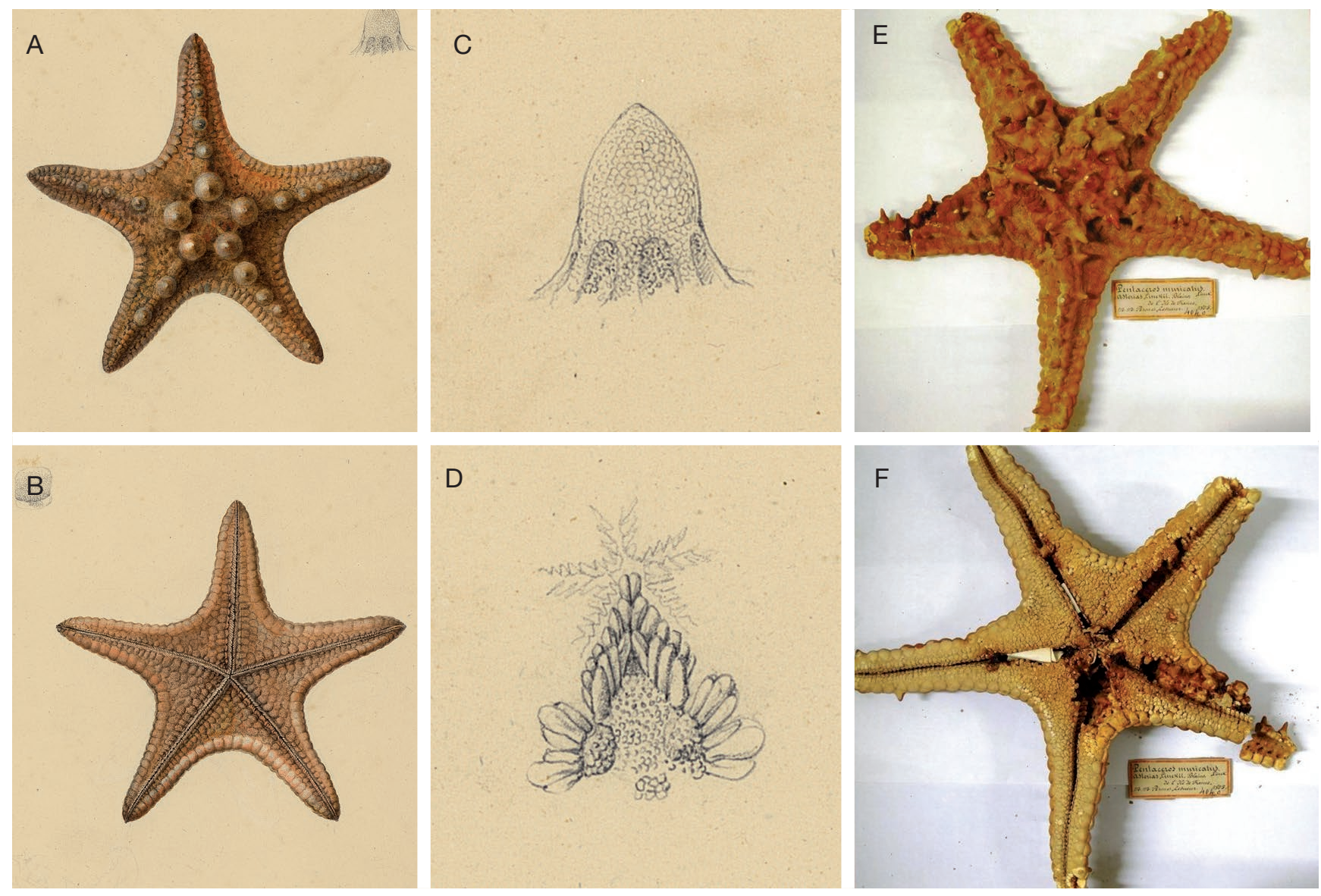

FIG. 23. - Asterias nodosa Lamarck, 1816, A-D, varieties 1 \& 2: A, B, abactinal (A) and actinal (B) surfaces; C, enlarged abactinal tubercule, D, interradial arc ( $\mathrm{MHNH}$, Lesueur's collection 74055, details, courtesy of $\mathrm{MHNH})$; E, F, variety 3: abactinal $(\mathbf{E})$ and actinal $(\mathbf{F})$ surfaces $(\mathrm{MNHN}-\mathrm{IE}-2017-837)$.

\section{nodosa Lamarck, 1816, Asterias}

(Fig. 22)

Asterias nodosa Lamarck, 1816: 557.

REMARK

Considering the MNHN collection and the works of Linck (1733) and Bruguière (1791), Lamarck cited three varieties of Asterias nodosa which in fact correspond to two different species.

nodosa var. 1 \& 2 Lamarck, 1816, Asterias

(Fig. 23)

Asterias nodosa Lamarck, 1816: 557.

Asterias nodosa Linnaeus, 1758 : 661.

Protoreaster nodosus - Clark $1993: 318$.

CuRrent status. - Protoreaster nodosus (Linnaeus, 1758).

MATERIAL EXAMINED. - MHNH; Lesueur drawings collection; ref. 74055; Baudin expedition (1800-1804) ; Péron and Lesueur leg.

Distribution. - Tropical East Indian ocean and tropical West Pacific. nodosa var. 3 Lamarck, 1816, Asterias

(Fig. 23E-F)

Asterias nodosa Lamarck, $1816: 557$

REVISED STATUS. - Asterias nodosa var. 3 is newly synonymized here with Protoreaster lincki (Blainville, 1830).

MATERIAL EXAMINED. - Mauritius • MNHN-IE-2017-837; specimen from the Baudin expedition (1800-1804); Péron and Lesueur leg.

Distribution. - Tropical West Indian ocean.

\section{REMARK}

P. lincki differs markedly from $P$. nodosus in having some of the distal supero-marginal plates bearing laterally-projecting spines. Also red and brown-beige are the dominant colours of abactinal and supero-marginal plates in $P$. lincki while they are of a varied brown in $P$. nodosus. Note also that $P$. lincki is very common in the west part of the Indian Ocean while P. nodosus is in the West Pacific.

\section{obtusangula Lamarck, 1816, Asterias}

(Fig. 24)

Asterias obtusangula Lamarck, 1816: 556. 

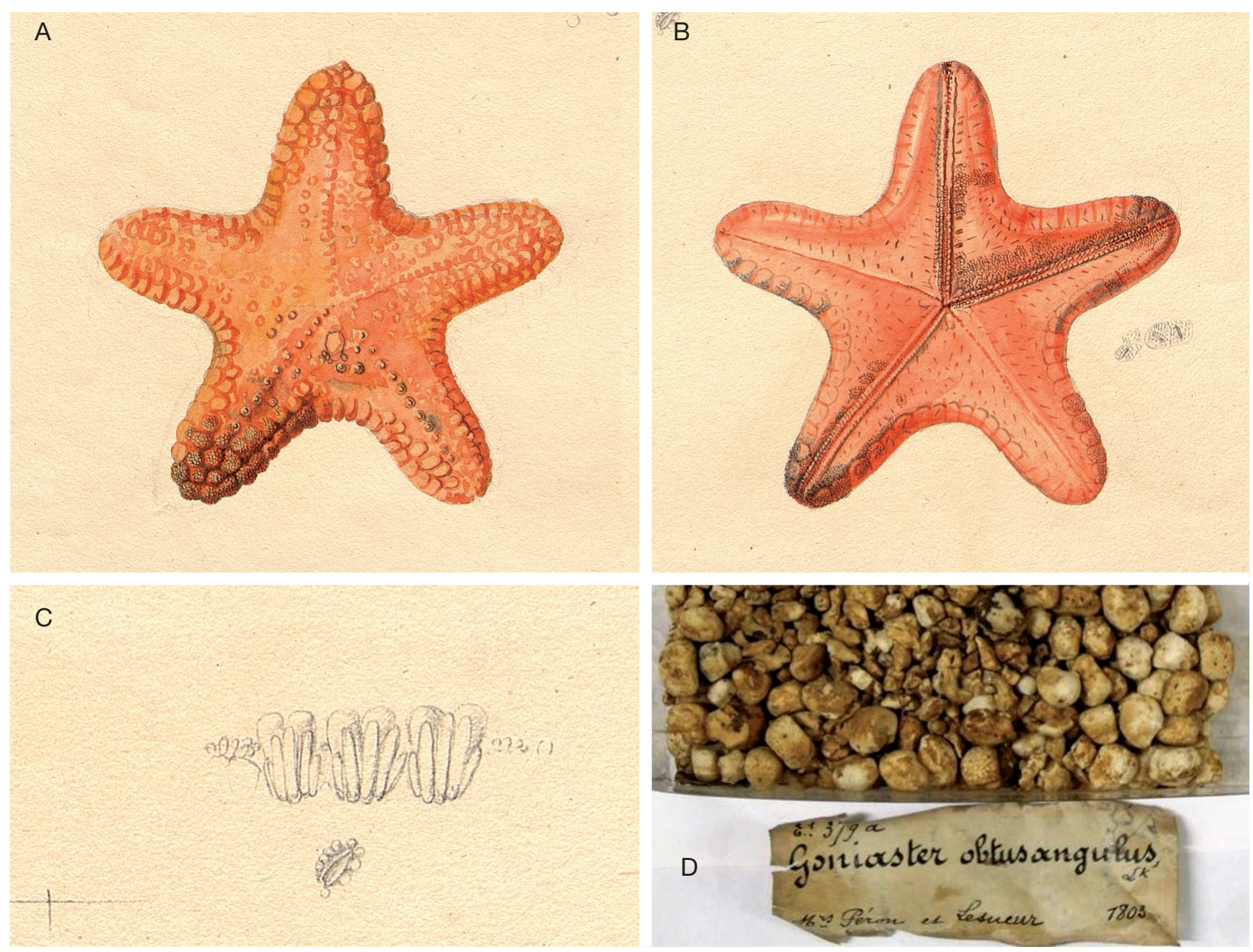

FIG. 24. - Asterias obtusangula Lamarck, 1816: A, B, abactinal (A) and actinal (B) surfaces; C, adambulacral spines and a sessile pedicellaria; D, remains of the holotype (A-C, MHNH, Lesueur collection 74051, details, courtesy of MHNH; D, MNHN-IE-2014-92).

\section{Pseudoreaster obtusangulus - Clark 1993: 318.}

CURRENT STATUS. - Pseudoreaster obtusangulus (Lamarck, 1816).

MATERIAL EXAMINED. — South Seas • MNHN-IE-2014-92; holotype (fragments); Baudin expedition (1800-1804); Péron and Lesueur leg. • MHNH; Lesueur drawings collection; ref. 74051; Baudin expedition.

Distribution. — North-west Australia.

\section{ocellifera Lamarck, 1816, Asterias}

(Fig. 25)

\section{REMARK}

To accommodate the Lamarckian species Asterias ocellifera, Gray (1840) established the genus Nectria. Yet Gray had not seen Lamarck's type specimens of $A$. ocellifera. When working on asteroids of the genus Nectria housed in the British Museum, Perrier (1875) realised that the species $N$. ocellifera sensu Gray was different from the species described by Lamarck while sharing some similarities with the second Paris specimen also identified as $A$. ocellifera by Lamarck. He consequently proposed the new name Nectria ocellata for Gray's specimens and gave a precise description of one of the Gray's individuals that will be considered later as the lectotype of the species (Zeidler \& Rowe 1986). As a consequence, the second specimen of Lamarck, while collected by Péron and Lesueur and being representative of the Perrier's species, is not a type of Nectria ocellata Perrier, 1875.

Asterias ocellifera Lamarck, 1816: 553 (part).

Nectria ocellifera-Clark 1993: 305.

CURRENT STATUS. - Nectria ocellifera (Lamarck, 1816).

Material EXAMINED. — South Seas • MNHN-IE-2014-24: holotype; Baudin expedition (1800-1804); Péron and Lesueur leg. - MHNH; Lesueur drawings collection; ref. 74020 and 74050; Baudin expedition.

Distribution. $-N$. ocellifera is restricted to the south part of West Australia.

\section{ocellata Perrier, 1875, Nectria}

(Fig. 26)

Asterias ocellifera (part) Lamarck, 1816: 553.

Nectria ocellata Perrier, 1875: 188. — Clark 1993: 305. 

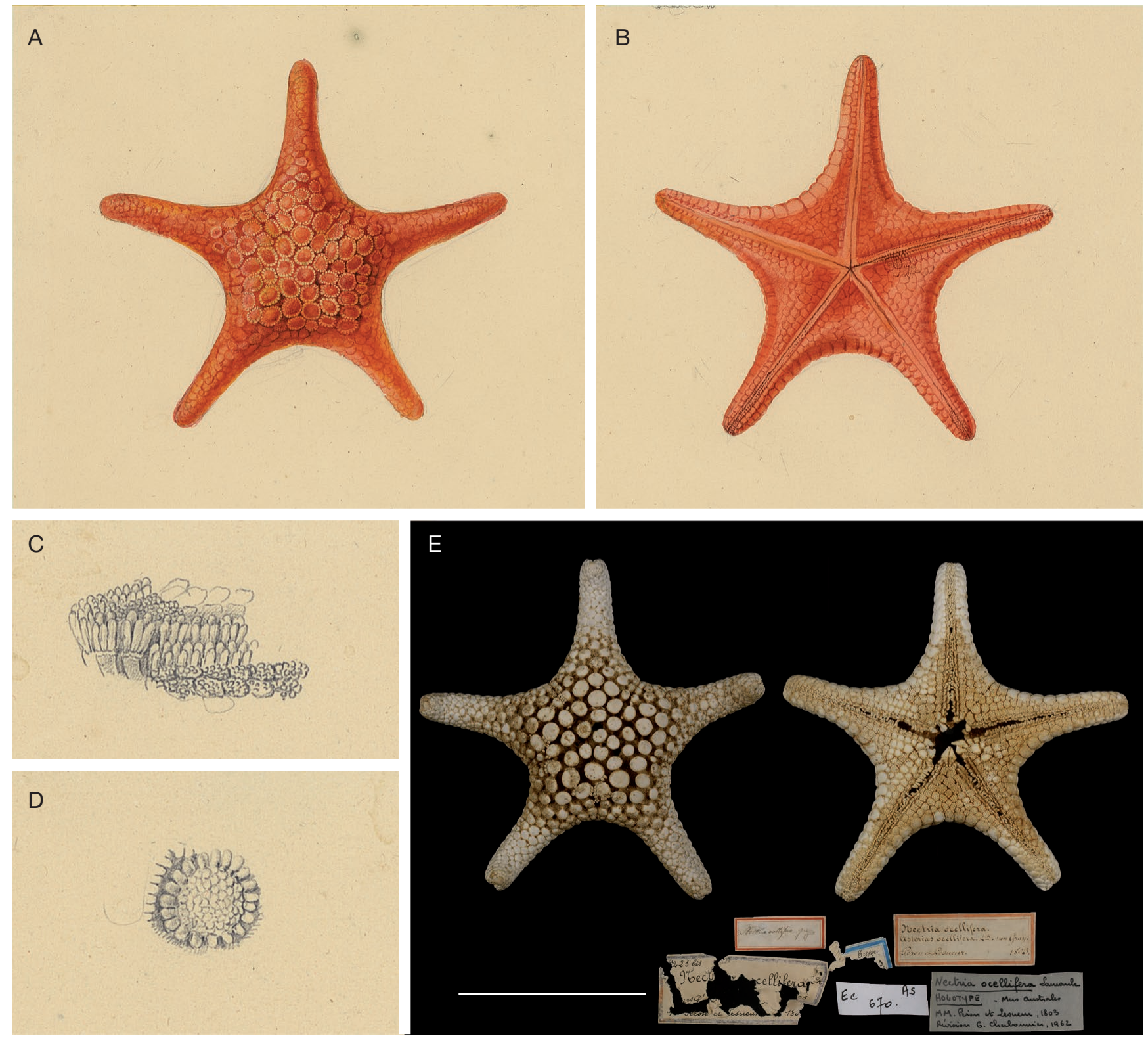

FIG. 25. - Asterias ocellifera Lamarck, 1816: A, abactinal (A) and actinal (B) surfaces; C, interradial arc and adambulacral spines; $\mathbf{D}$, abactinal tabula showing the scalelike peripheral granules; E, holotype of Asterias ocellifera (A-D, MHNH, Lesueur collection 74050, details, courtesy of MHNH; E, MNHN-IE-2014-24). Scale bar: 50 mm.

MATERIAl EXAMINED. — South Seas • MNHN-IE-2014-23; Baudin expedition (1800-1804); Péron and Lesueur leg.; syntype of Asterias ocellifera Lamarck, 1816.

DisTRIBUTION. - N. ocellata is mainly distributed along the coasts of South Australia, Victoria and New South Wales, and around Tasmania.

\section{ophidiana Lamarck, 1816, Asterias}

(Fig. 27)

Asterias ophidiana Lamarck, 1816: 567.

Ophidiaster ophidianus - Clark \& Downey 1992: 281.

CurRent STATUS. - Ophidiaster ophidianus (Lamarck, 1816).
Distribution. - From western Mediterranea to the Gulf of Guinea.

\section{REMARK}

Lamarck' type material could not be found in the MNHN.

penicillaris Lamarck, 1816, Asterias

(Fig. 28)

Asterias penicillaris Lamarck, 1816: 555.

Asterinopsis penicillaris - Clark 1993: 215.

CURRENT STATUS. - Asterinopsis penicillaris (Lamarck, 1816).

MATERIAL EXAMINED. - MHNH; Lesueur drawings collection; ref. 74007; Baudin expedition; Péron and Lesueur leg. 


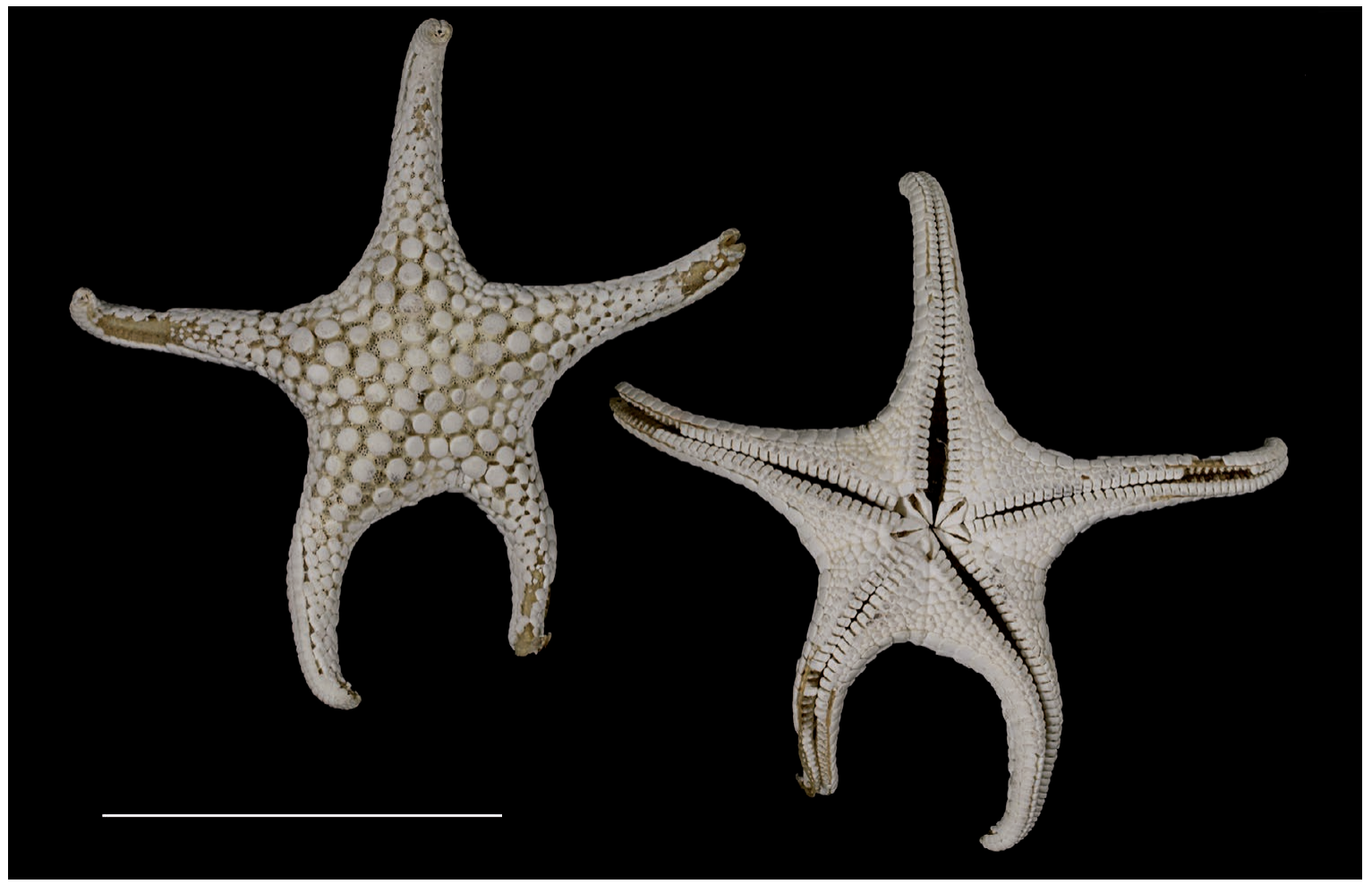

FIG. 26. - Nectria ocellata Perrier, 1875 [non Asterias ocellifera Lamarck, 1816]. Individual collected by Péron and Lesueur. Scale bar: 50 mm.

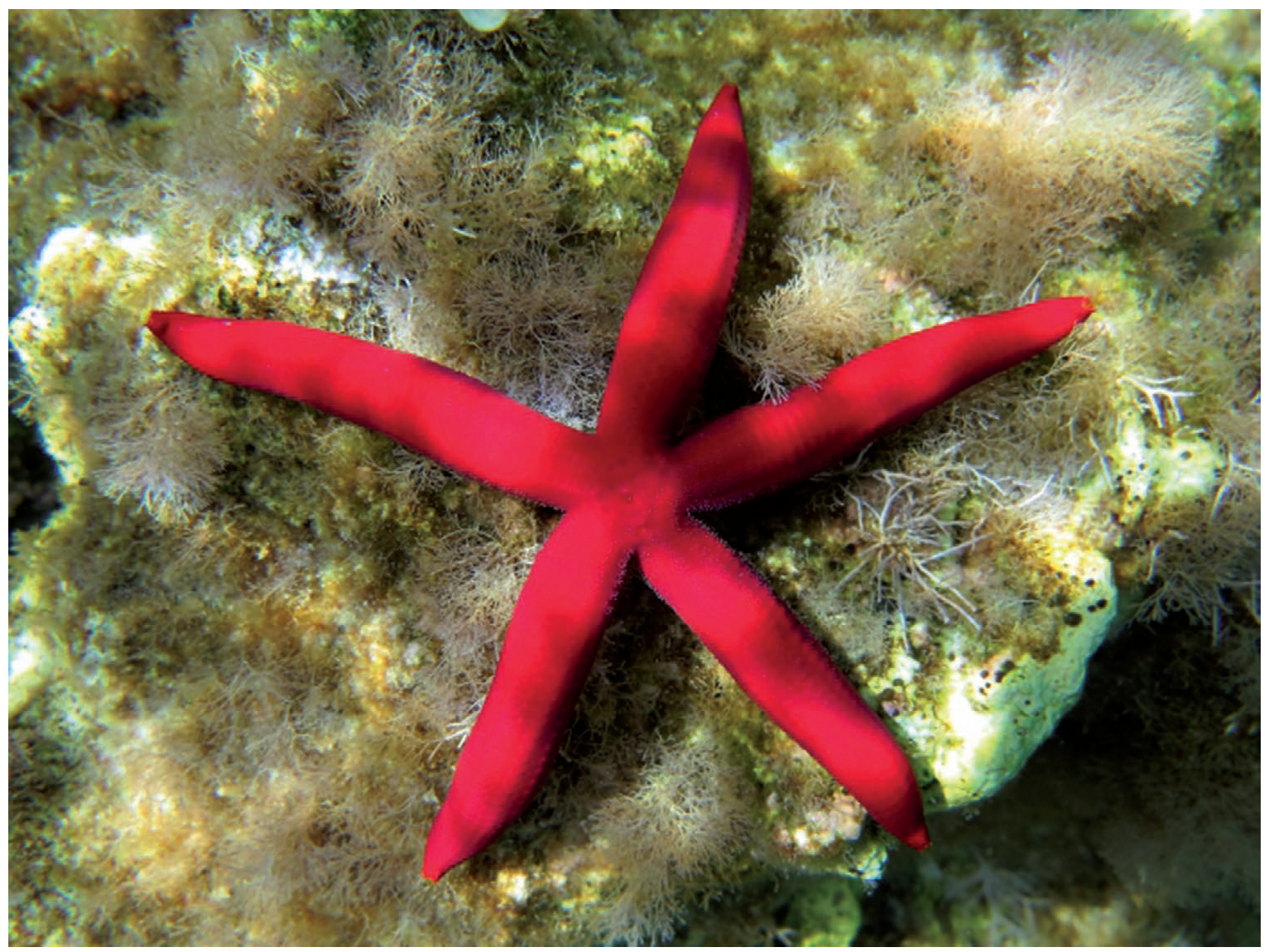

FIG. 27. - Asterias ophidiana Lamarck, 1816 (Worms image. Photo by Roberto Pilon). 

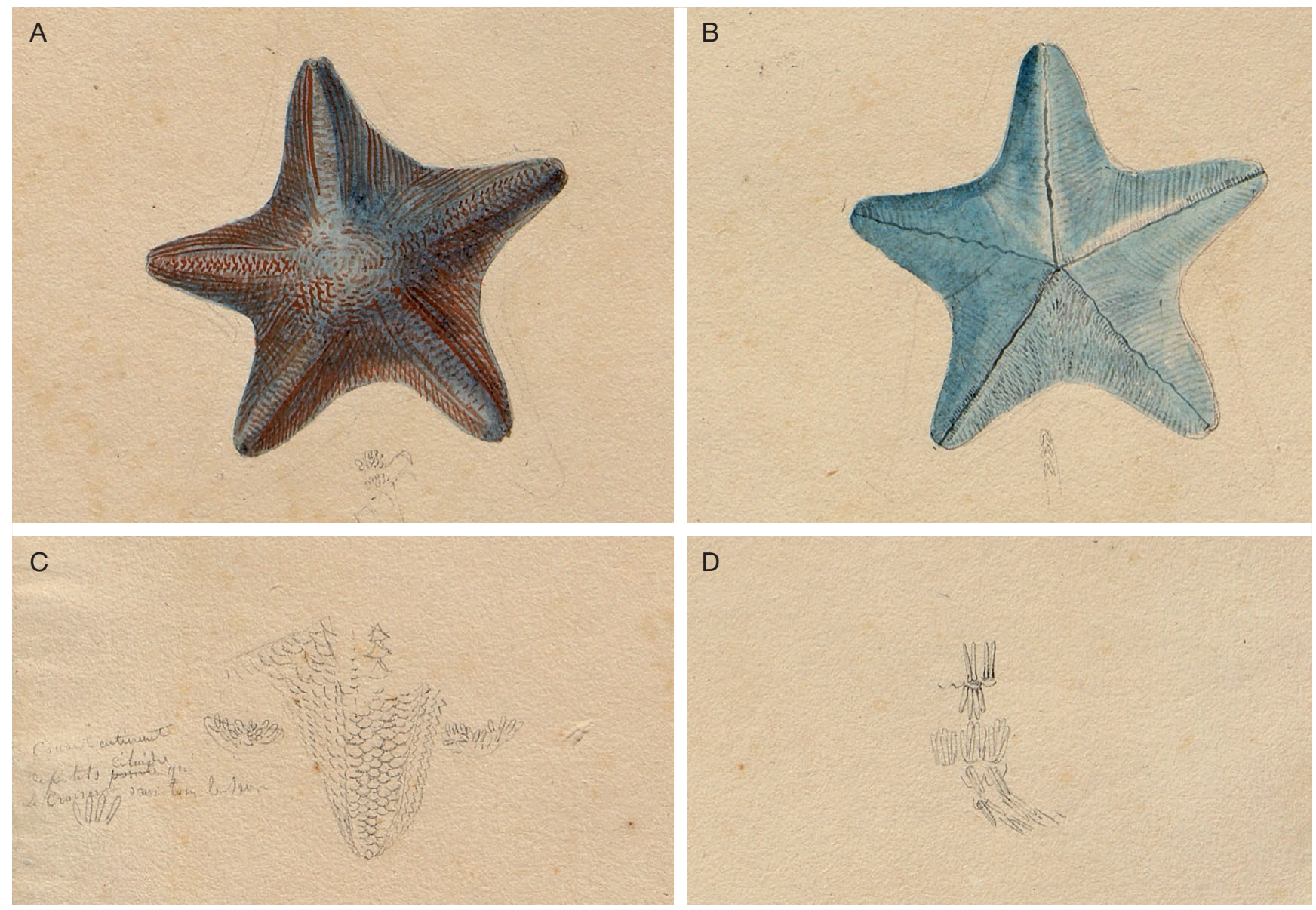

FIG. 28. - Asterias penicillaris Lamarck, 1816: A, B, abactinal (A) and actinal (B) surfaces; C, arrangement of arm abactinal plates (text "wholly covered by small cylinders intersecting in all directions"); D, adambulacral and actinolateral spines (MHNH, Lesueur collection 74007, details, courtesy of MHNH).

\section{REMARK}

Collected during the Baudin expedition by Péron and Lesueur, Asterias penicillaris cannot consequently come from the Atlantic, as written by Lamarck (1816). The species was discussed by Müller \& Troschel (1842, under the name Asteriscus penicillaris) who reported its colouration from Lesueur's drawings: “oben mit bläulichen Grunde und rothbraunen Stacheln ; unten blau [above, bluish background with brownish-red spines; below blue]". These authors mentioned that the species is in the Berlin Museum and said nothing about its presence in Paris. The absence of individuals in Paris could explain why Perrier (1875) did not comment on the species.

The Péron and Lesueur's material of the species could not be found in the MNHN.

\section{pentagonula Lamarck, 1816, Asterias}

(Fig. 29)

Asterias pentagonula Lamarck, 1816: 554.

Anthenea pentagonula-Clark 1993: 296.

CURRENT STATUS. - Asterias pentagonula is newly synonymized here with Tosia australis Gray, 1840.
Material EXAMINED. - MHNH; Lesueur drawings collection; ref. 74021; Baudin expedition; Péron and Lesueur leg.

DisTribution. - South of Australia and Tasmania.

REMARKS

Asterias pentagonula was often said to belong to the genus Anthenea which includes asteroids with an enlarged disc and relatively short though well-individualised arms. However, Lamarck's description emphasises the peculiar shape of the species as "Aplati, presque discoïde, avec des angles courts [flat, almost disc-shaped, with shallow angles]". Such an appearance does not fit with Anthenea and rather suggests that the species belongs to the genus Tosia Gray, 1840, a suggestion that is consistent with both its origin (South Seas) and collectors (Péron and Lesueur). Several authors consider that Asterias pentagonula is a Chinese species. This is unlikely and could result from the synonymy of $A$. pentagonula with Anthenea chinensis Gray, 1840 in Müller \& Troschel (1842: 57). This is a rather strange proposal as Gray's species originated from the China-Japan area while Asterias pentagula came from the South Seas. Liao \& Clark (1995: 99) consider that these species are two different taxa. The MNHN specimens identified Anthenea pentagonula belong to the species Anthenea australiae Döderlein, 1915; see previously under that species. 

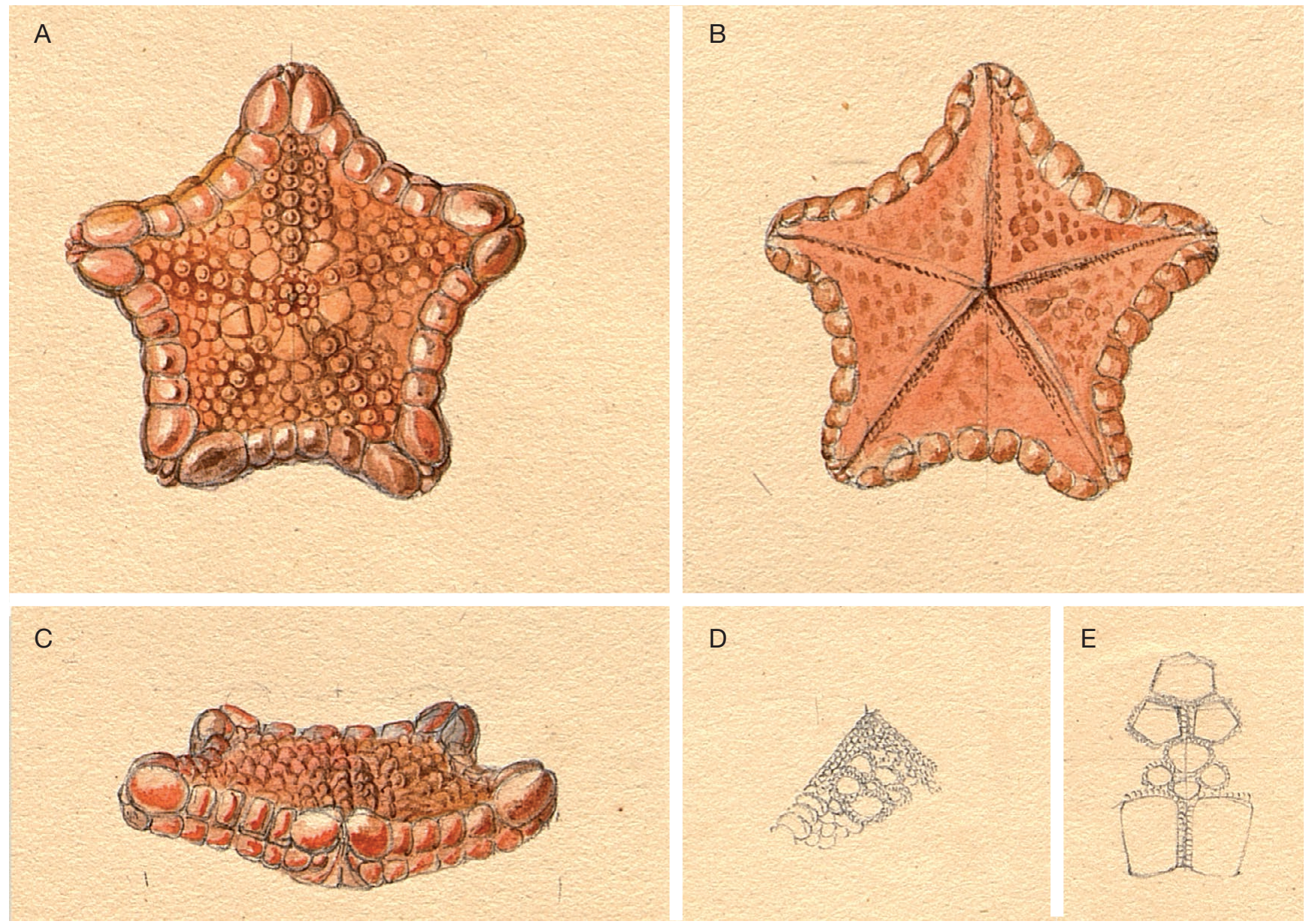

FIG. 29. - Asturias pentagonula Lamarck, 1816: A, B, abactinal (A) and actinal (B) surfaces; C, profile view; E, interradial arc; $\mathbf{F}$, superomarginal and abactinal plates (MHNH, Lesueur collection 74021, details, courtesy of $\mathrm{MHNH}$ ).

\section{pleyadella Lamarck, 1816, Asterias}

(Fig. 30)

Asterias pleyadella Lamarck, 1816: 553.

Goniodiscaster pleyadella - Clark 1993: 301.

CURRENT STATUS. - Asterias pleyadella is newly synonymized here with Protoreaster sp. (juvenile).

Material EXAMINED. — South Seas • MNHN-IE-2014-124: 2 syntypes; Baudin expedition (1800-1804); Péron and Lesueur leg. • MHNH; Lesueur drawings collection; ref. 74030; Baudin expedition.

DisTRIBUTION. - Protoreaster species commonly occur throughout the Indo-West Pacific.

\section{REMARK}

When discussing Asterias pleyadella status, Perrier (1875: 275) suggested that its representatives are juveniles closer to oreasterids than to goniasterids. He consequently related A. pleyadella to the genus Pentaceros Gray, 1840. This makes sense, indeed, considering the overall shape of the individuals, their carinate arms and, particularly, the five radially positioned tubercles surrounding the central part of the disc.
I agree with Perrier's analysis but consider Asterias pleyadella a juvenile Protoreaster, the common oreasterid genus of the Indian Ocean. Lesueur drew (pencil drawings) the best preserved individual of $A$. pleyadella.

\section{punctata Lamarck, 1816, Asterias}

(Fig. 31)

Asterias punctata Lamarck, 1816: 553.

Petricia punctata - Clark 1993: 321.

CURRENT STATUS. - Asterias punctata is newly newly synonymized here with Asteropsis carinifera (Lamarck, 1816).

MATerial eXAmineD. - South Seas • MNHN-IE-2014-31; 2 syntypes of Asterias carinifera; Baudin expedition (1800-1804); Péron and Lesueur leg. $\bullet$ MHNH; Lesueur drawings collection; ref. 74043; Baudin expedition.

\section{REMARKS}

There is a strange confusion between Lamarck's Asterias punctata and Lamarck's Asterias vernicina, the two species being erroneously considered synonymous. This confusion presumably arose 
A

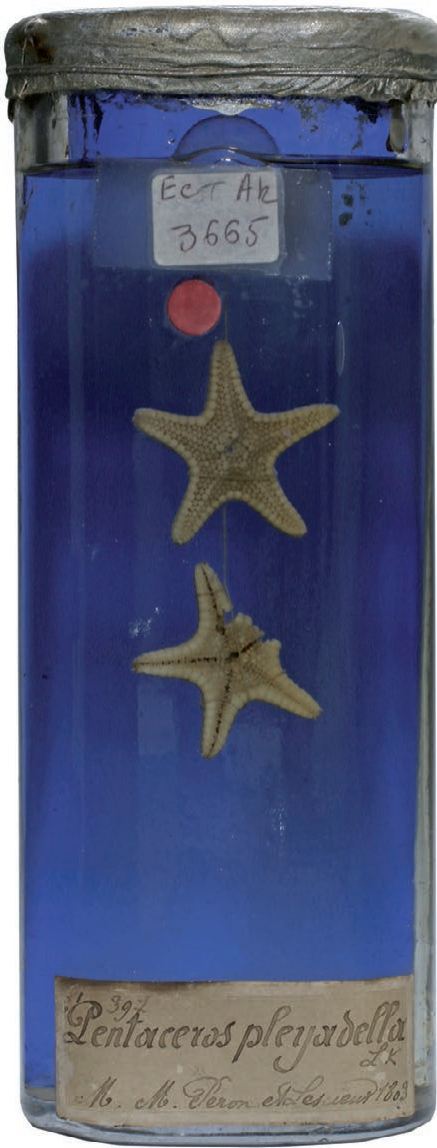

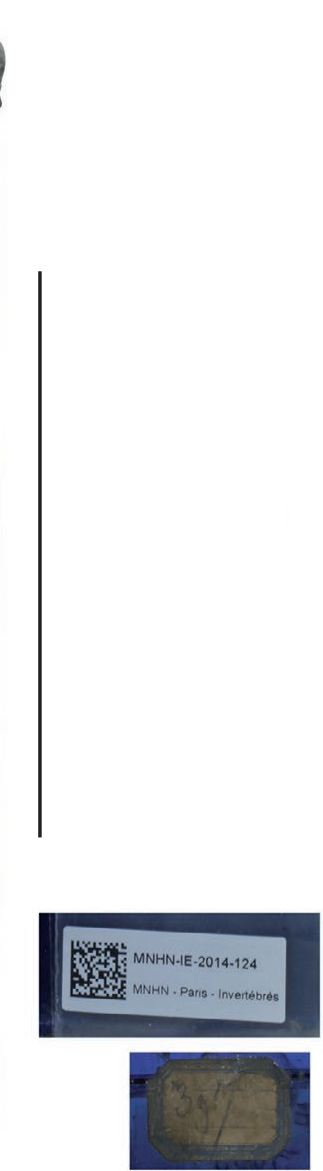
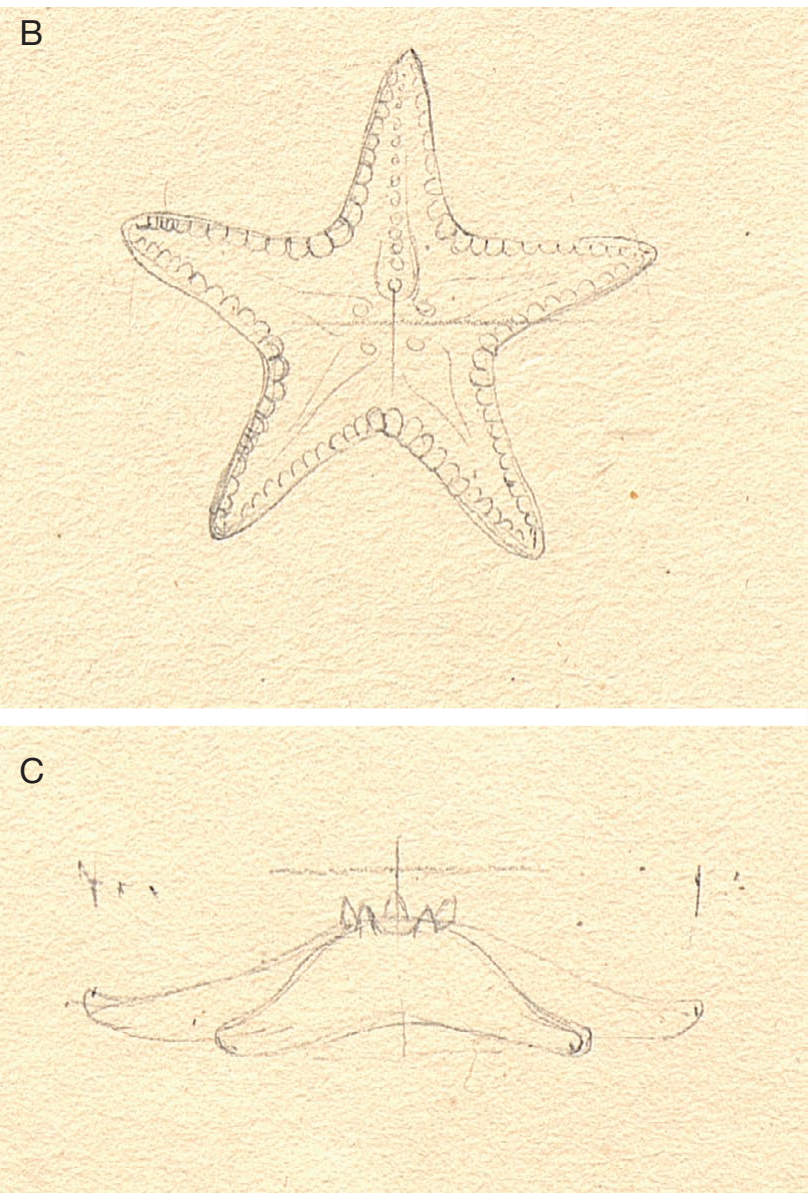

FIG. 30. - Asterias pleyadella Lamarck, 1816: A, syntypes of the species; B, C, pencil drawings of abactinal surface and profile of the intact specimen (A, MNHNIE-2014-124; B, C, MHNH, Lesueur collection 74030, details, courtesy of MHNH).

from Perrier's stay in the British Museum in the early 1870 s. After having compared London and Paris asteroid specimens, he proposed, with reason, to synonymyse Lamarck's Asterias vernicina and Gray's Petricia punctata, which he confirmed in his 1875 revision, combining the two species under the name Petricia vernicina. Of course, this did not imply that Lamarck's Asterias punctata was also a synonym of Lamarck's Asterias vernicina, a synonymy which was, however, tacitly accepted by subsequent authors. The situation became still more confused as neither Müller \& Troschel (1842) nor Perrier (1875) discussed Lamarck's Asterias punctata. They found no trace of $A$. punctata individuals in the MNHN which would mean the specimens have been lost for quite a long time.

Lamarck's Latin diagnosis of Asterias punctata is as follows: "pentagona, inermis, utrinque tessellata; tesselis dorsi sinuatoangulatis, punctatis; margine articulato [pentagonal, spineless [and] checkered on both sides; upper side perforate with rounded tiles; articulated arm". Nota: "Tiles" refer to abactinal plates and 'perforate' to papulae.] Both this diagnosis and the MNHN pictures of Asteropsis carinifera syntypes are clearly reminiscent of the shape of juveniles Asteropsis carinifera already illustrated by Loriol (1885: 67, pl 20 figs 7-10). One may therefore conclude that $A$. punctata and $A$. carinifera are synonyms, the former corresponding to the juvenile form of the species. purpureus Perrier, 1869, Ophidiaster

(Fig. 32)

Ophidiaster purpureus Perrier, 1869: 61; 1875: 127.

Ophidiaster hemprichi-Clark 1993: 349.

CURRENT STATUS. — Ophidiaster hemprichi (Müller \& Troschel, 1842).

Material EXAMINED. - Seychelles • MNHN-IE-2014-404; holotype; Rousseau leg.; 1842.

DisTRIBUTION. - The species is rather common in the tropical Indo-West-Pacific.

\section{REMARK}

Perrier (1875: 127) established the species O. purpureus to accommodate one of the two specimens that Lamarck identified as a representative of his new species Asterias cylindrica, (O. purpureus is now considered a synonym of Ophidiaster hemprichi (Müller \& Troschel, 1842)). Yet Perrier did not consider the second Lamarck specimen of Asterias cylindrica to designate the holotype of $O$. purpureus. He assigned as holotype an individual collected by Rousseau in the Seychelles in 1842 . 

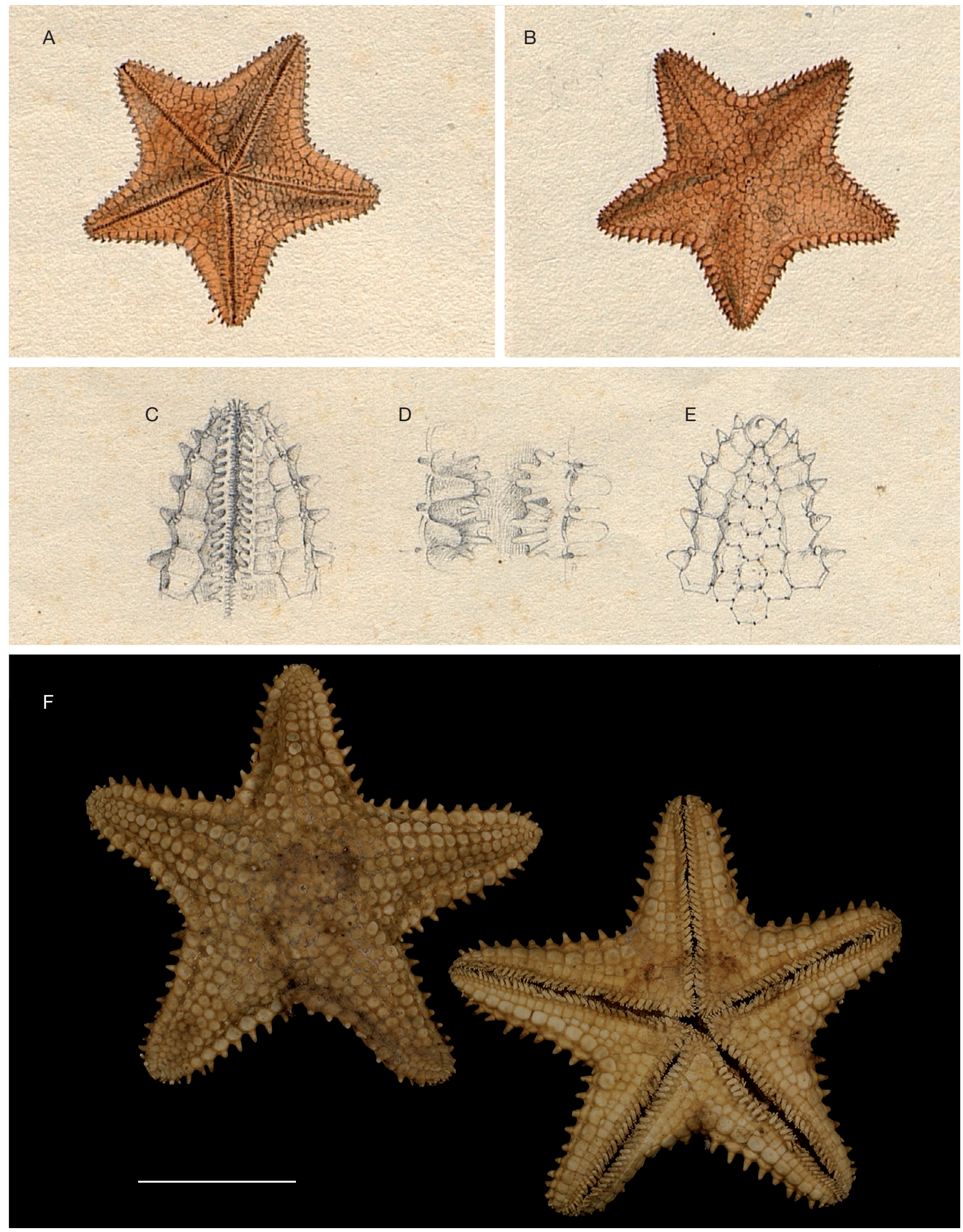

FIG. 31. - Asterias punctata Lamarck, 1816: A, B, abactinal and actinal surfaces; C, E, abactinal and actinal sides of the arm tip; D, furrow and subambulacral spines; F, syntypes of the species MNHN-IE-2014-31 (A-E: MHNH, Lesueur collection 74043, details, courtesy of MHNH). 

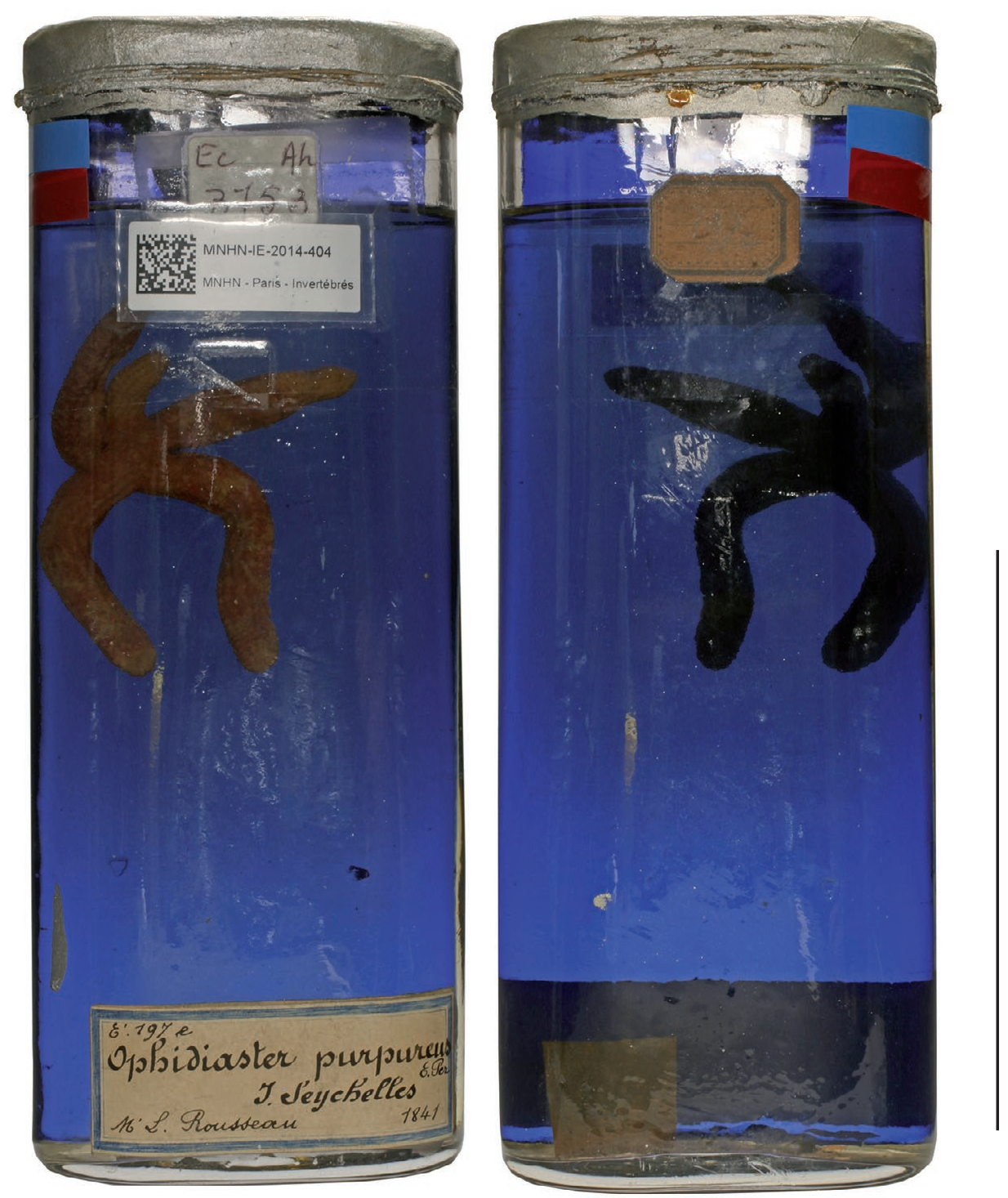

FIG. 32. - Ophidiaster purpureus Perrier, 1869 abactinal and actinal surfaces of the holotype (MNHN-IE-2014-404).

rosacea var. lobis quindenis Lamarck, 1816, Asterias (Fig. 33)

Asterias rosacea Lamarck, 1816: 558.

Anseropoda rosacea-Clark 1993: 206.

CURRENT STATUS. - Anseropoda rosacea (Lamarck, 1816).

MATERIAL EXAMINED. — MNHN-IE-2014-62; holotype; Baudin expedition (1800-1804); Péron and Lesueur leg. • MHNH; Lesueur drawings collection; ref. 7435; Baudin expedition.

Distribution. - West, north and north-east Australia, Indonesia, tropical West Pacific.

\section{REMARK}

Lamarck (1816) gave no type locality for the species. rosacea var. lobis senis Lamarck, 1816, Asterias

(Fig. 34)

Asterias rosacea Lamarck, 1816: 558.

Anseropoda rosacea - Clark 1993: 206.

CURRENT STATUS. - Anseropoda sp.

MATERIAL EXAMINED. — MHNH; Lesueur drawings collection; ref. 74001; Baudin expedition; Péron and Lesueur leg.

REMARK

Lamarck's variety lobis senis corresponds to a still unidentified six-armed species of Anseropoda Nardo, 1834. Lamarck gave no locality for the species. Lamarck's material of Asterias rosacea var. lobis senis could not be found in the MNHN. 

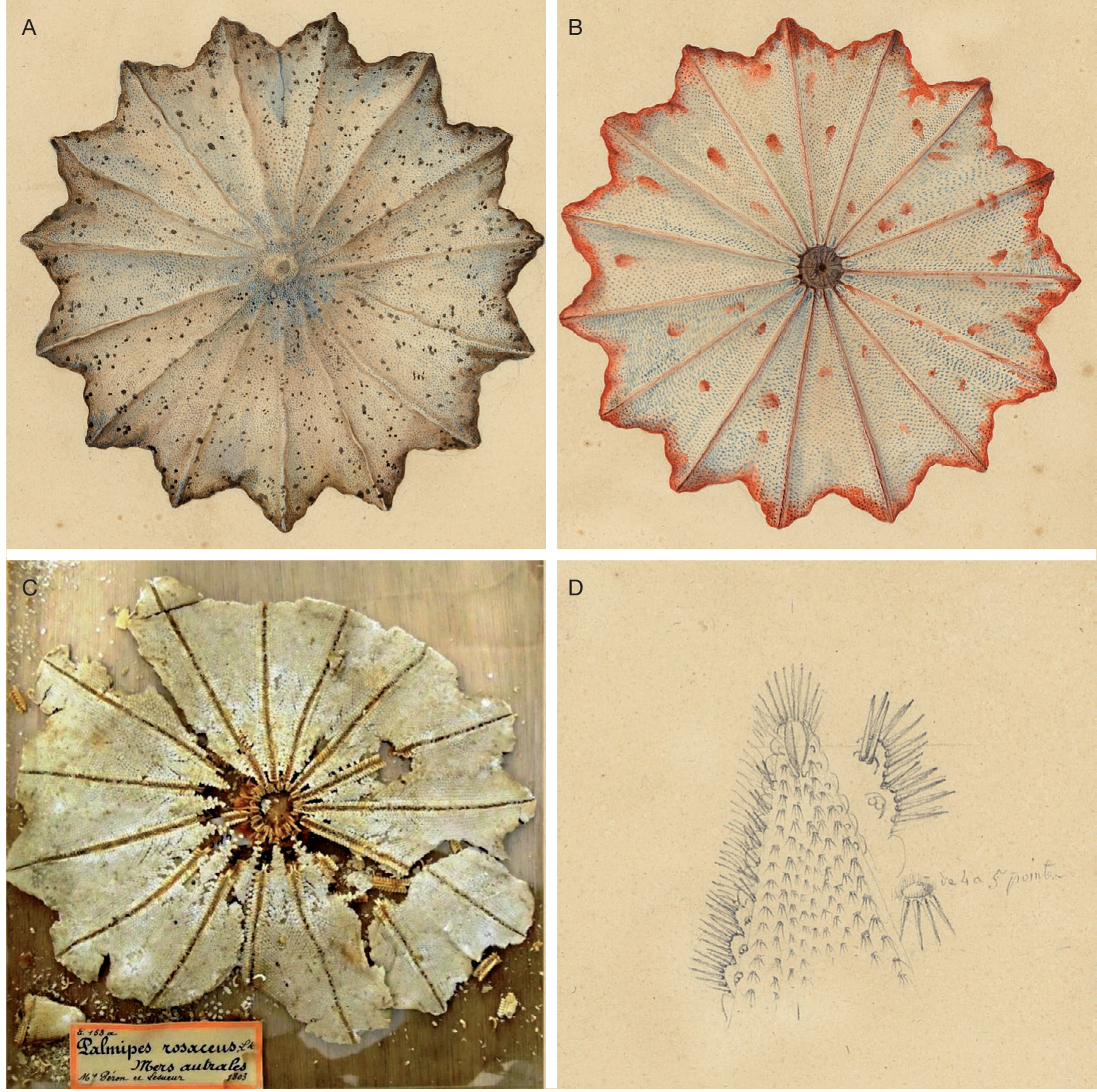

FlG. 33. - Asterias rosacea var. lobis quindenis Lamarck, 1816: A, B, abactinal (A) and actinal (B) surfaces; C, holotype of $A$. rosacea (actinal view); D, interradial arc and adambulacral spines (text: "from 4 to 5 spikes"); (A, B, D, MHNH, Lesueur collection 74035, details, courtesy of MHNH; C, MNHN-IE-2014-62).

senegalensis Lamarck, 1816, Asterias

(Fig. 35)

Asterias senegalensis Lamarck, 1816: 567.

Luidia senegalensis - Clark \& Downey 1992: 21.

CURRENT STATUS. — Luidia senegalensis (Lamarck, 1816).

MATERIAL EXAMinED. - Senegal • MNHN-IE-2014-160; 2 syntypes; Adanson leg.

Distribution. - Florida to south of Brazil.
REMARK

Except for its two syntypes, the species Luidia senegalensis was never reported from African coasts. The type locality could be wrong, as it is the case for several localities given by Adanson (see Madsen 1950: 205) and the syntypes most probably come from the West Indies. In fact, L. senegalensis is a shallow water species from western Atlantic. Note that the MNHN has a third specimen of L. senegalensis, also collected by Adanson. It belonged to the Michelin collection and was presumably not seen by Lamarck. 

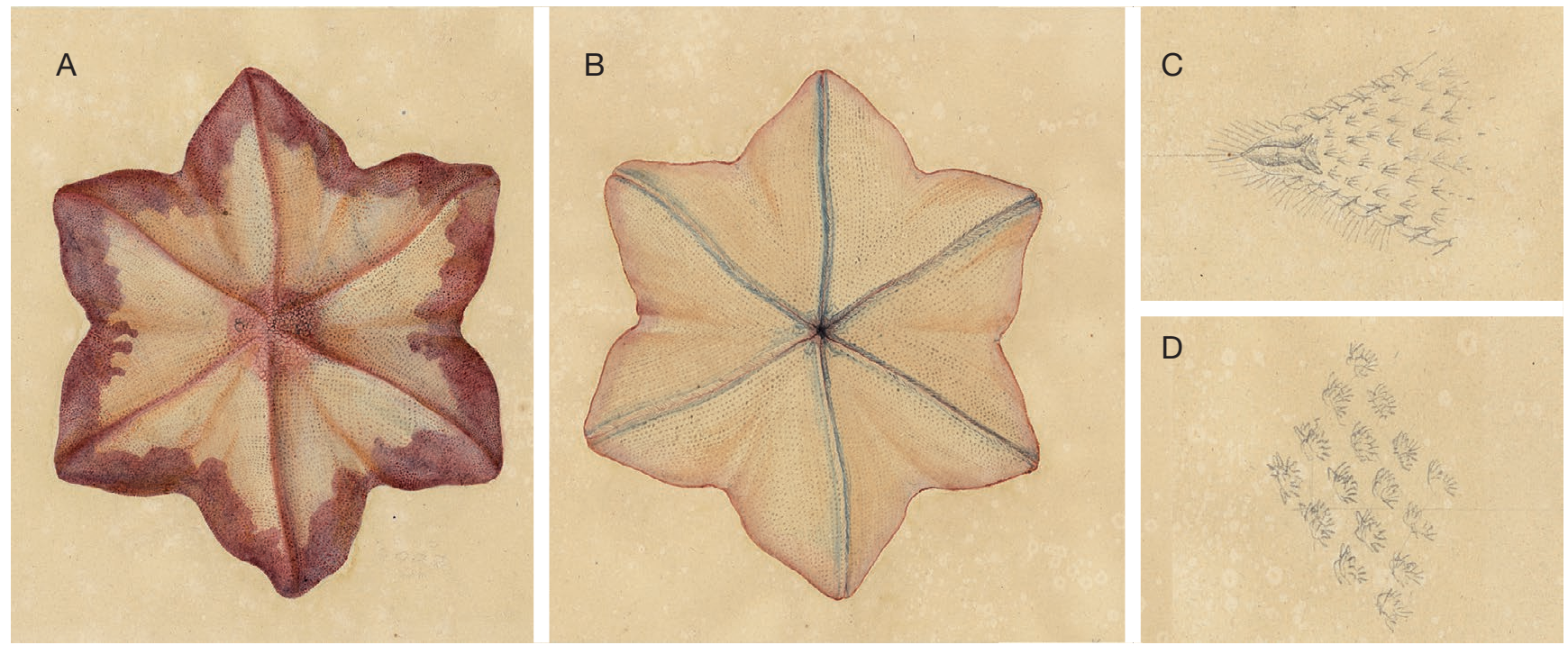

FIG. 34. - Asterias rosacea var. lobis senis Lamarck, 1816: A, B, abactinal (A) and actinal (B) surfaces; C, interradial arc; D, arrangement of abactinal spines ( $\mathrm{MHNH}$, Lesueur collection 74001, details, courtesy of MHNH).

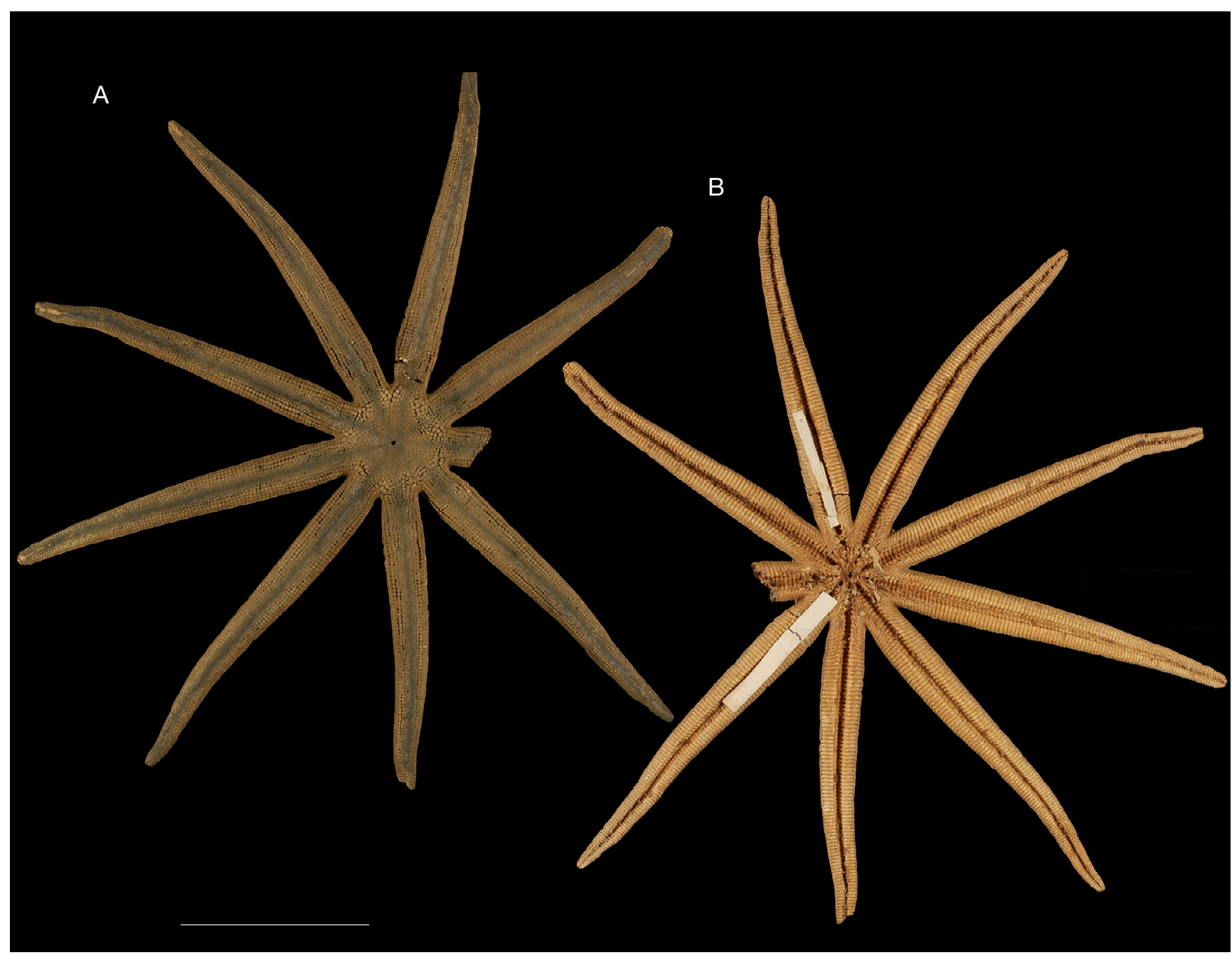

FIG. 35. - Asterias senegalensis Lamarck, 1816: abactinal (A) and actinal (B) surfaces of a syntype (MNHN-IE-2014-160). 

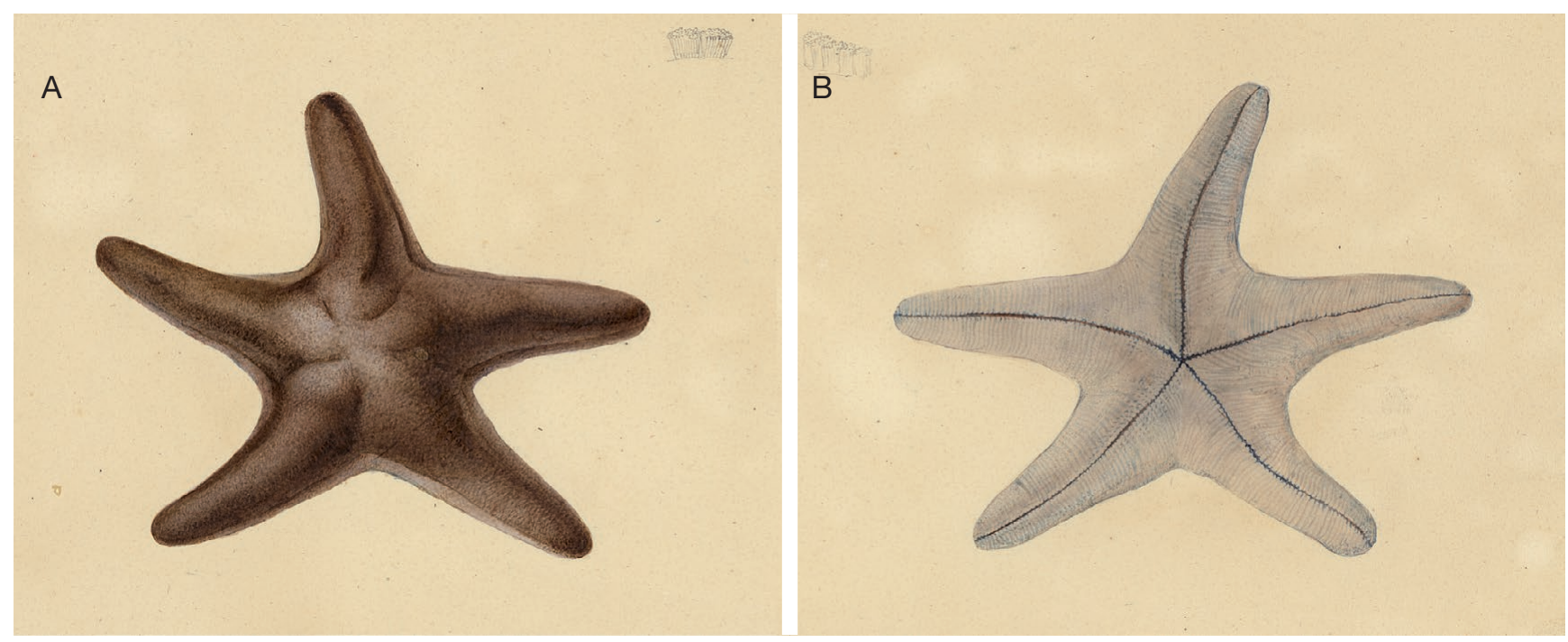

FIG. 36. - Asteriscus setaceus Müller \& Troschel, 1842: A, B, abactinal (A) and (B) actinal surfaces (MHNH, Lesueur collection 74024, details, courtesy of $\mathrm{MHNH})$.

setaceus Müller \& Troschel, 1842, Asteriscus

(Fig. 36)

Asteriscus setaceus Müller \& Troschel, 1842: 43.

Asterina setacea-Clark 1993: 213.

CURRENT STATUS. - Asteriscus setaceus is newly synonymized here with Paranepanthia grandis (H. L. Clark, 1928).

MATERIAL EXAMINED. - MNHN-IE-2014-638; holotype; Baudin expedition (1800-1804); Péron and Lesueur leg. • MHNH; Lesueur drawing collection 74024; Baudin expedition.

Distribution. - South coast of Australia, Tasmania

\section{REMARK}

According to a note by Lesueur, the edges of abactinal surface of the individual are whitish. The holotype is altered and the drawings lack details. The species is tentatively identified here Paranepanthia grandis due to its shape with flat edge and to the oblique orientation of the actinal plates and armamement (see also the website Atlas of living Australia https://www.ala.org.au/, species Paranepanthia grandis (H.L. Clark, 1928)).

striata Lamarck, 1816, Asterias

(Fig. 37)

Asterias striata Lamarck, 1816: 564.

Valvaster striatus - Clark 1993: 322.

CURRENT STATUS. — Valvaster striatus (Lamarck, 1816).

MATERIAL EXAMINED. - Mauritius • MNHN-IE-2014-36; holotype; Mathieu leg.; 1812. subulata Lamarck, 1816, Asterias

(Fig. 38)

Asterias subulata Lamarck, 1816: 568.

Chaetaster longipes - Clark 1993: 189.

Current status. - Chaetaster longipes (Bruzelius, 1805).

Distribution. - Mediterranea and East Atlantic (from Portugal to Liberia).

\section{REMARK}

Lamarck gave no information on the origin of Asterias subulata specimen though its description strongly supports the synonymy with the species Chaetaster longipes. Lamarck's type material of Asterias subulata could not be found in the MNHN.

\section{subulata Gray, 1840, Metrodira}

(Fig. 39)

Metrodira subulata Gray, 1840: 280. — Clark 1996: 243.

CURrent STATUS. - Metrodira subulata Gray, 1840.

MATERIAL EXAMINED. - MHNH; Lesueur drawings collection; ref. 74017; Baudin expedition; Péron and Lesueur leg.

Distribution. - North part of Australia, Gulf of Bengal, Indonesia, Philippines.

REMARK

Péron and Lesueur's material of the species could not be found in the MNHN. 


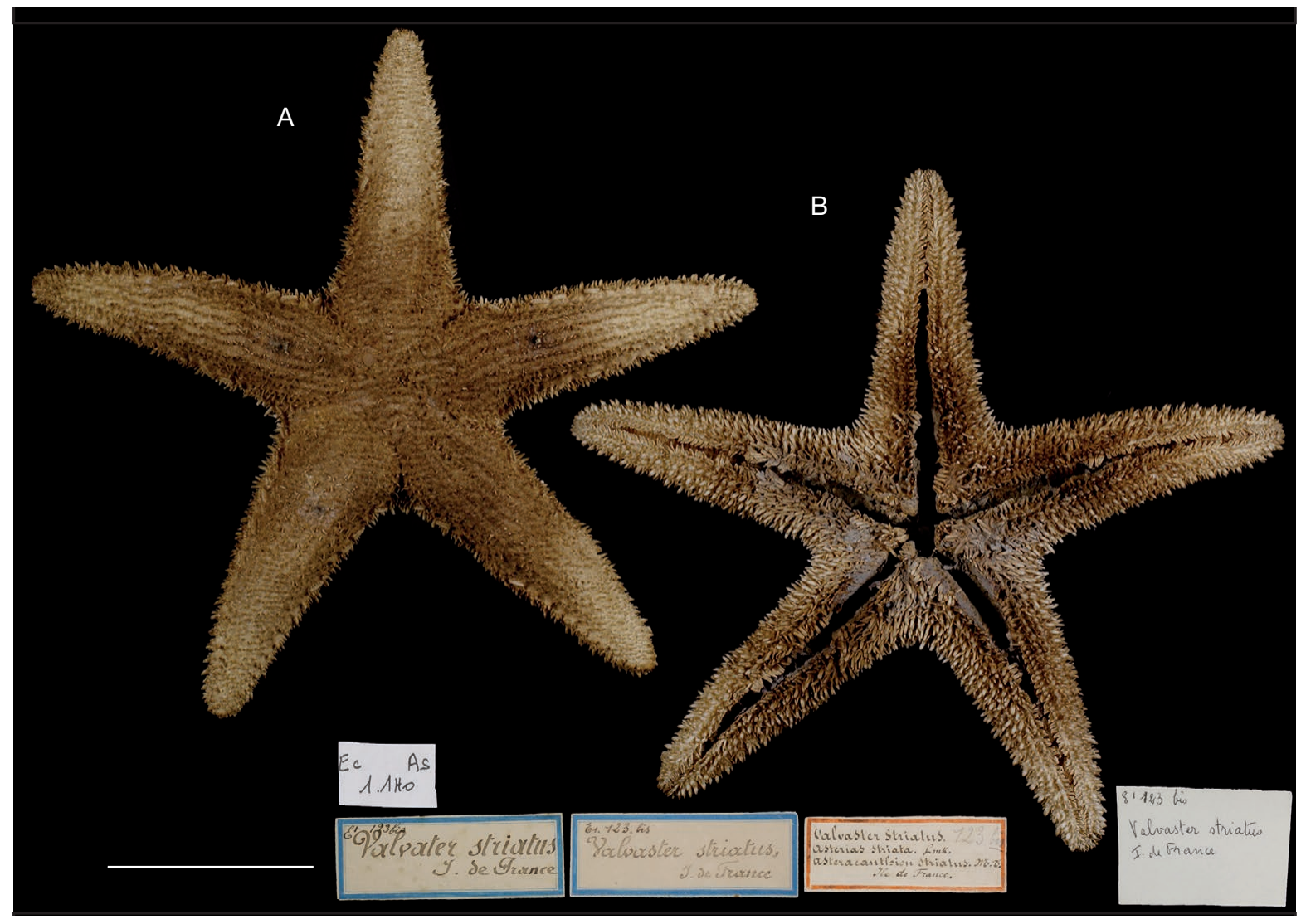

FIG. 37. - Asterias striata Lamarck, 1816: abactinal (A) and actinal (B) surfaces of the holotype (MNHN-IE-2014-36).

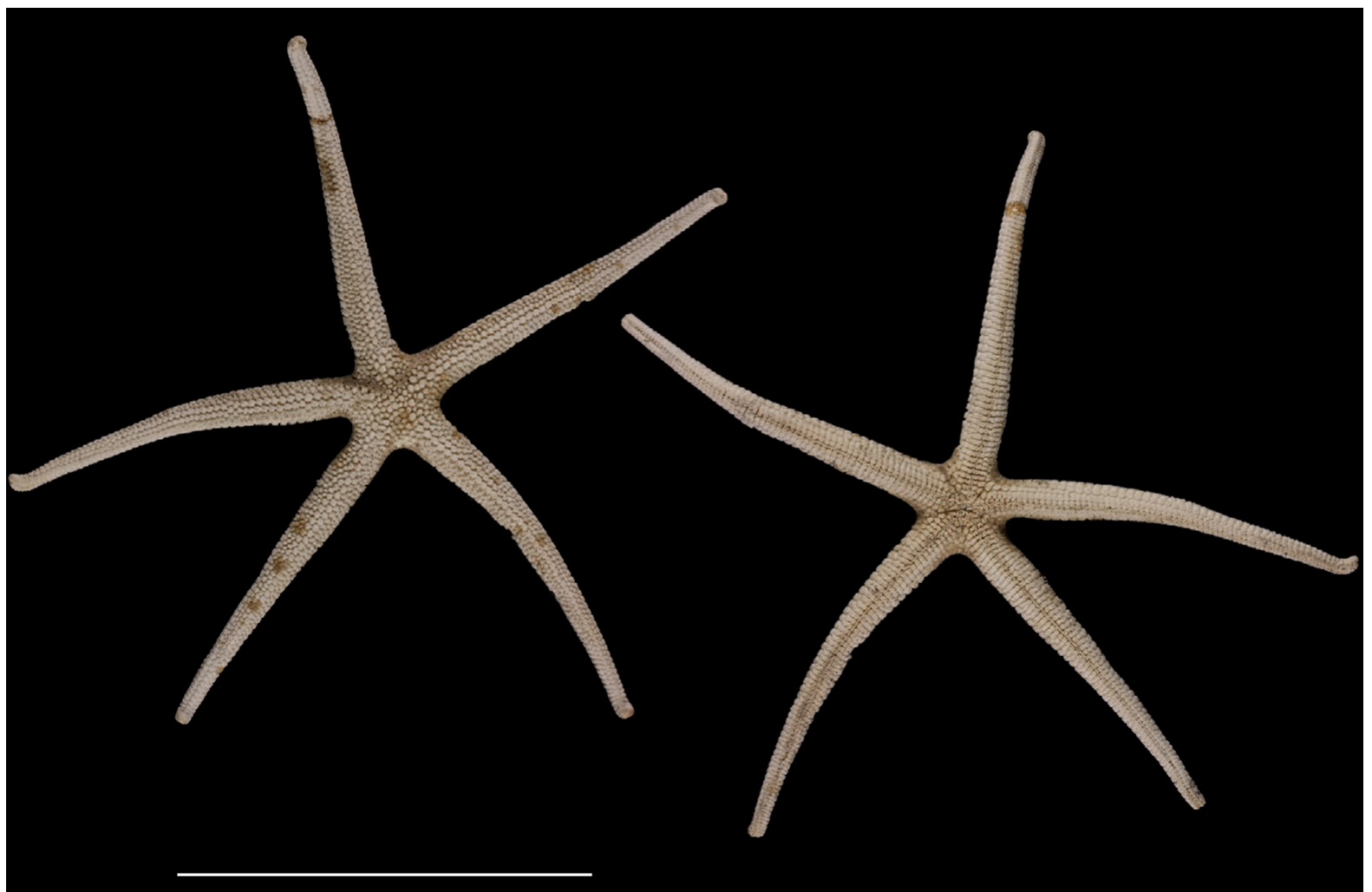

FIG. 38. - Chaetaster longipes Lamarck, 1816: abactinal and actinal surfaces of a specimen of the MNHN (MNHN-IE-2014-541). 

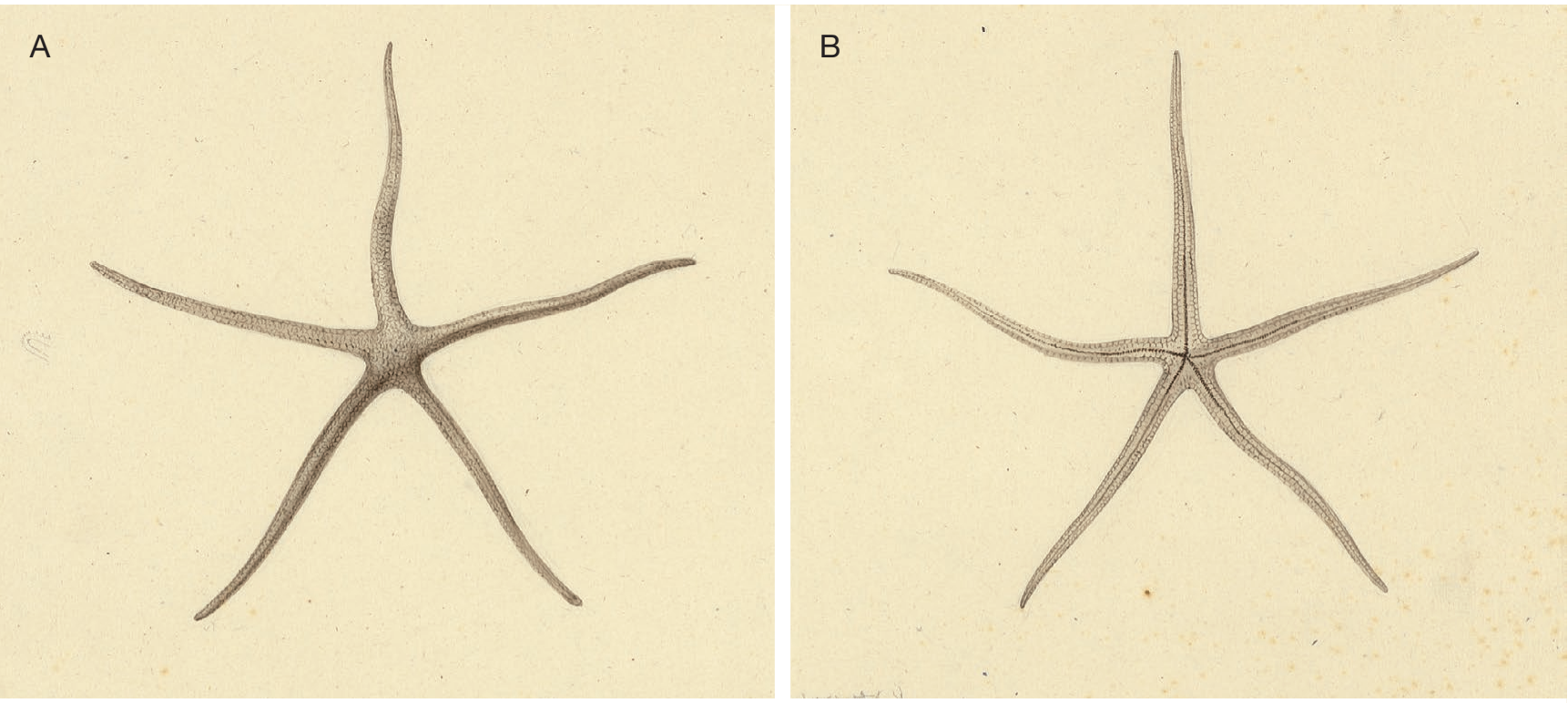

C

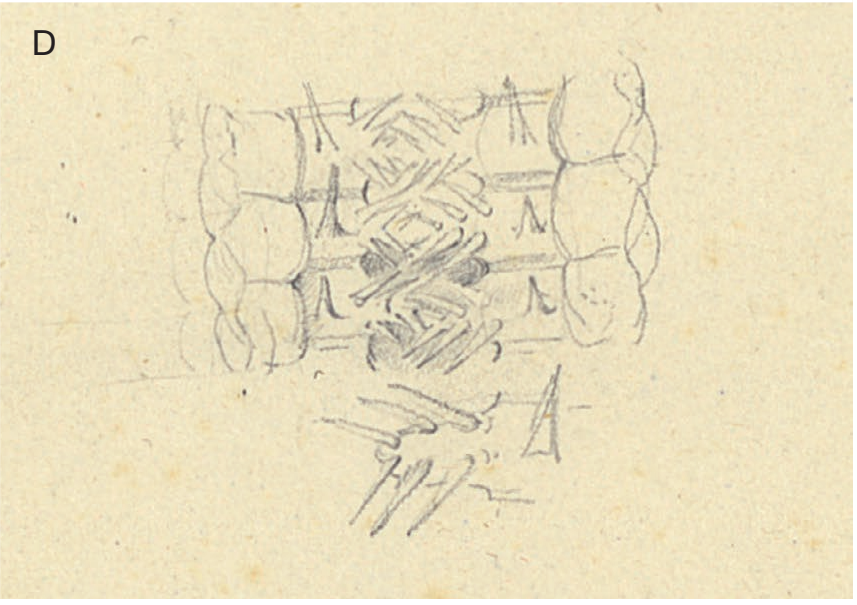

FIG. 39. - Metrodira subulata Gray, 1840: A, B, abactinal (A) and actinal (B) surfaces; C, abactinal structure of an arm section showing the minute granulation of abactinal plates and the arrangements of pairs or triplets of spines (text: 'above'); $\mathbf{D}$, actinal structure of an arm section showing the triangular inner part of adambulacral plates bearing six furrow spines and projecting above the ambulacral groove; note also the occurrence of a single broad erected subambulacral spine (MHNH, Lesueur collection 74017, details, courtesy of $\mathrm{MHNH})$.

tenuispina Lamarck, 1816, Asterias

(Fig. 40)

Asterias tenuispina Lamarck, 1816: 561.

Coscinasterias tenuispina - Clark \& Downey 1992: 427.

CuRrent STATUs. - Coscinasterias tenuispina (Lamarck, 1816).

Distribution. - Mediterranea; East Atlantic from Bay of Biscay to Cape Verde Islands; West Atlantic (North Carolina, Cuba, Bahamas, eastern Brazil).

\section{REMARK}

Lamarck's type material could not be found in the MNHN.

tessellata var. C and D Lamarck, 1816, Asterias

(Fig. 41)

Asterias tessellata var. C and D Lamarck, 1816: 552.
Astrogonium lamarckii Müller \& Troschel, 1842: 56, n. syn.

Goniaster tessellatus - Clark \& Downey 1992: 245.

CURRENT STATUS. — Goniaster tessellatus (Lamarck, 1816).

Distribution. - North Carolina to northern Brazil and Morocco to Gabon. Contrarily to what is sometimes reported, Goniaster tessellatus does not occur in the Indo-Pacific ocean.

\section{REMARK}

Lamarck's type material could not be found in the MNHN. Yet, Müller \& Troschel (1842), while giving no information on Lamarck's Asterias tessellata, described a new species (Astrogonium lamarckii) that they found in the Paris collection. Undoubtedly, Astrogonium lamarckii is the first junior synonym of Lamarck's Asterias tessellata. The holotype of the former is still kept in the MNHN (Fig. 41). It is to be assumed that the type specimen of Astrogonium lamarckii of Müller \& Troschel's would also be that of Lamarck's Asterias tessellata. 


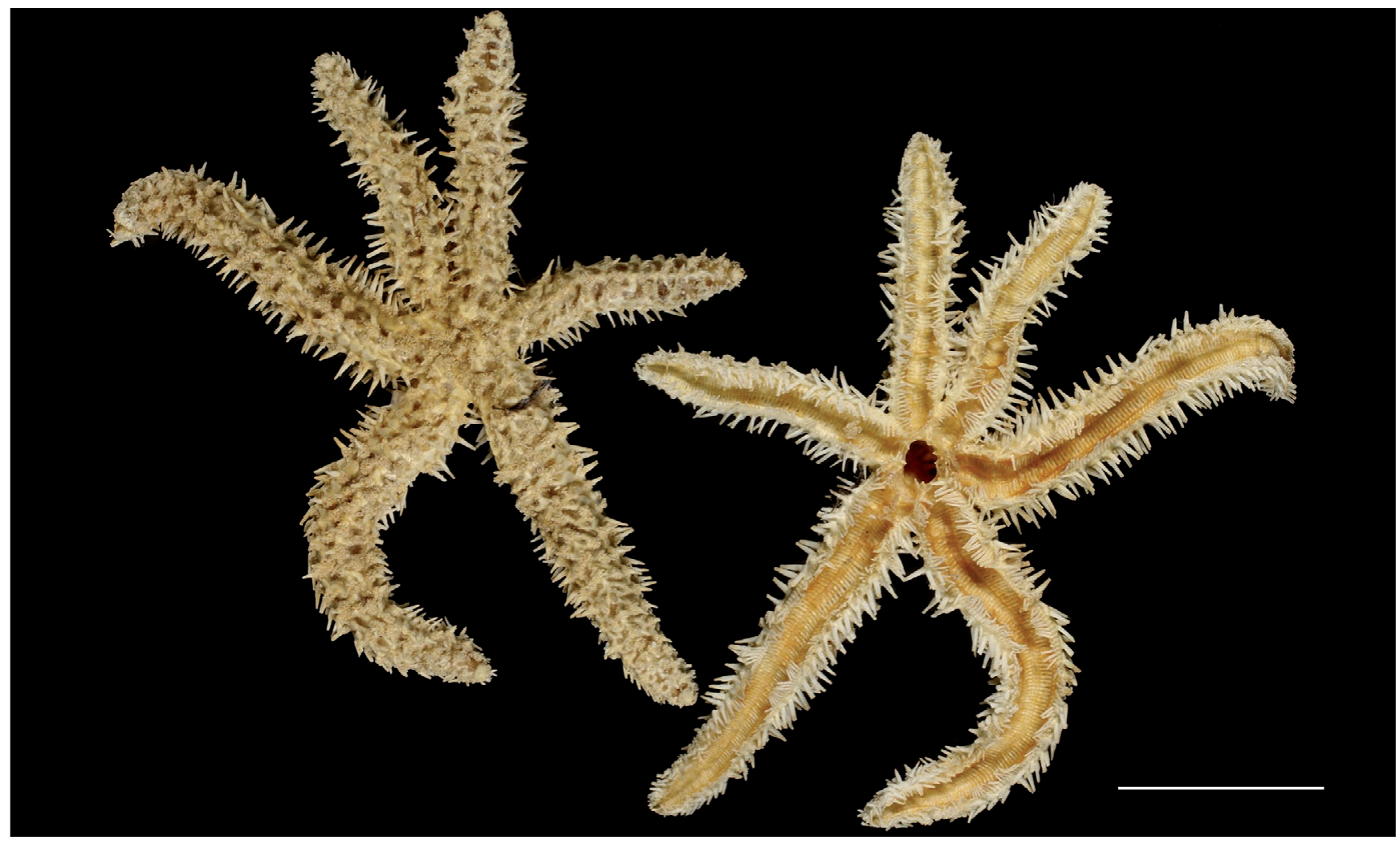

FIG. 40. - Asterias tenuispina Lamarck, 1816: abactinal and actinal surfaces of a specimen of the MNHN (MNHN-IE-2014-532).

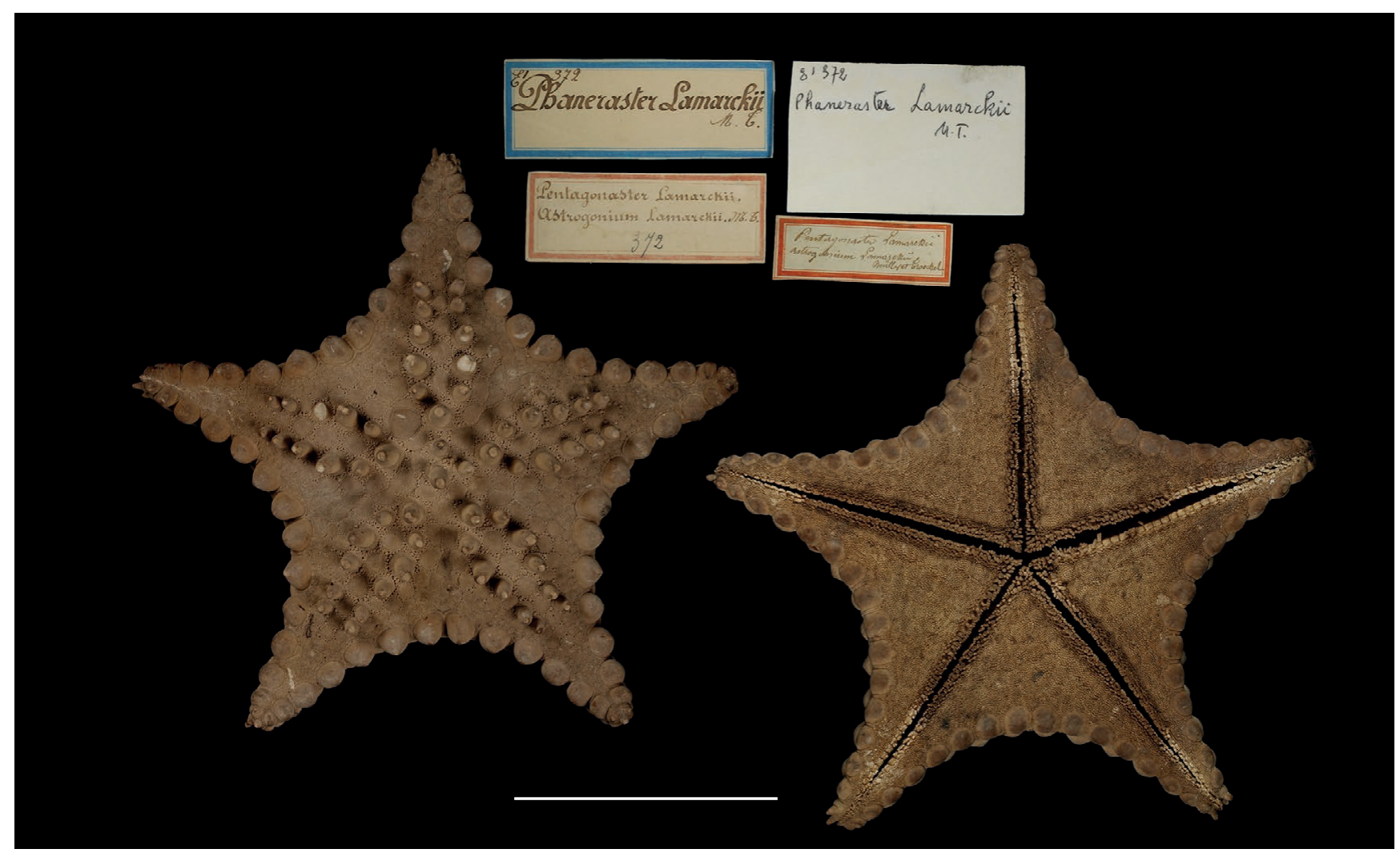

FIG. 41. - Astrogonium lamarcki Müller \& Troschel, 1842 (holotype MNHN-IE-2014-65), a junior synonym and putative type specimen of Asterias tessellata Lamarck, 1816: abactinal and actinal views. 

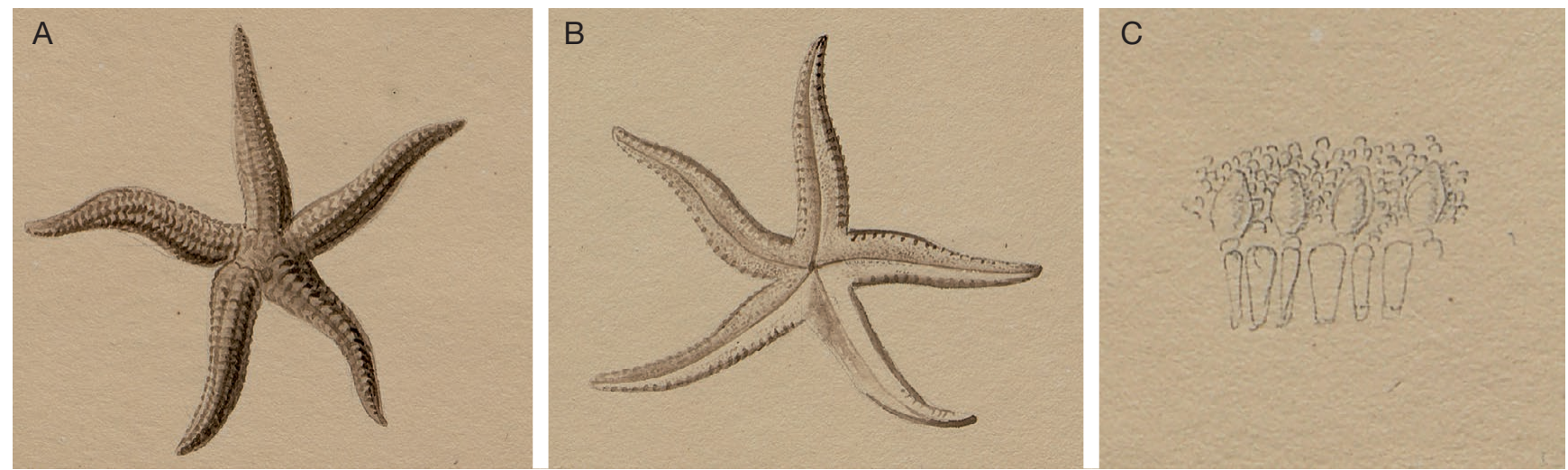

FIG. 42. - Linckia tyloplax H. L. Clark, 1914: A, B, abactinal (A) and actinal (B) surfaces; C, adambulacral spines (MHNH, Lesueur collection 74018, details, courtesy of MHNH).
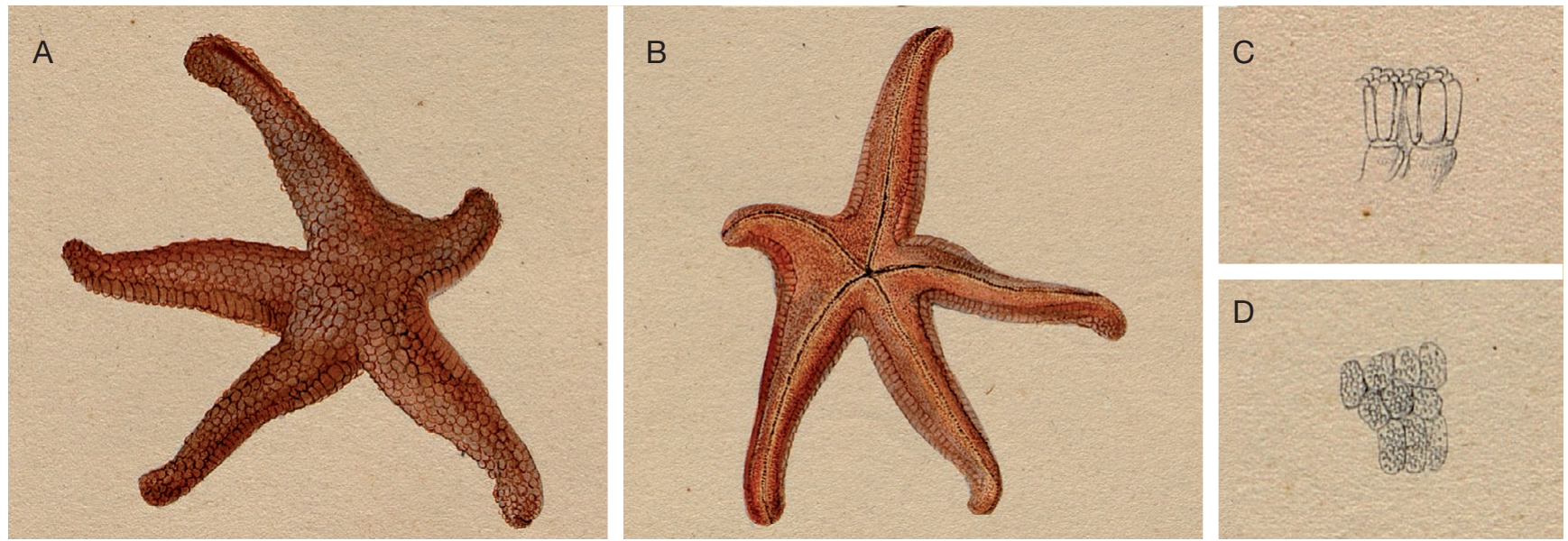

FIG. 43. - Asterias variolata Lamarck, 1816: A, B, abactinal (A) and actinal (B) surfaces; C, furrow spines; D, abactinal plates and granules (MHNH, Lesueur collection 74037, details, courtesy of $\mathrm{MHNH})$.

\section{tyloplax H. L. Clark, 1914, Linckia}

(Fig. 42)

Linckia tyloplax H. L. Clark, 1914: 147.

Hacelia tyloplax - Rowe \& Gates 1995: 85.

CurRent STATUS. - Hacelia tyloplax (H. L. Clark, 1914) (see Rowe \& Gates 1995: 85).

MATERIAL EXAMINED. - MHNH; Lesueur drawings collection; ref. 74018; Baudin expedition; Péron and Lesueur leg.

Distribution. - West Australia.

REMARK

Péron and Lesueur's material of the species could not be found in the MNHN.

\section{variolata Lamarck, 1816, Asterias}

(Fig. 43)

Asterias variolata Lamarck, 1816: 565.

Nardoa variolata - Clark 1993: 343.
CURRENT STATUS. - Nardoa variolata (Bruzelius, 1805).

MATERIAL EXAMINED. - MHNH; Lesueur drawings collection; ref. 74037; Baudin expedition; Péron and Lesueur leg.

Distribution. - East coast of Africa.

\section{REMARK}

Lamarck's material could not be found in the MNHN.

\section{vernicina Lamarck, 1816, Asterias}

(Fig. 44)

Asterias vernicina Lamarck, 1816: 554.

Petricia vernicina - Clark 1993: 321.

Current STATUS. - Petricia vernicina (Lamarck, 1816).

Material EXAMINED. - South Seas • MNHN-IE-2014-28; 2 syntypes; Baudin expedition (1800-1804); Péron and Lesueur leg. • MHNH; Lesueur drawings collection; ref. 74049; Baudin expedition.

Distribution. - South coast of Australia to New South Wales, Tasmania, temperate South-West Pacific. 

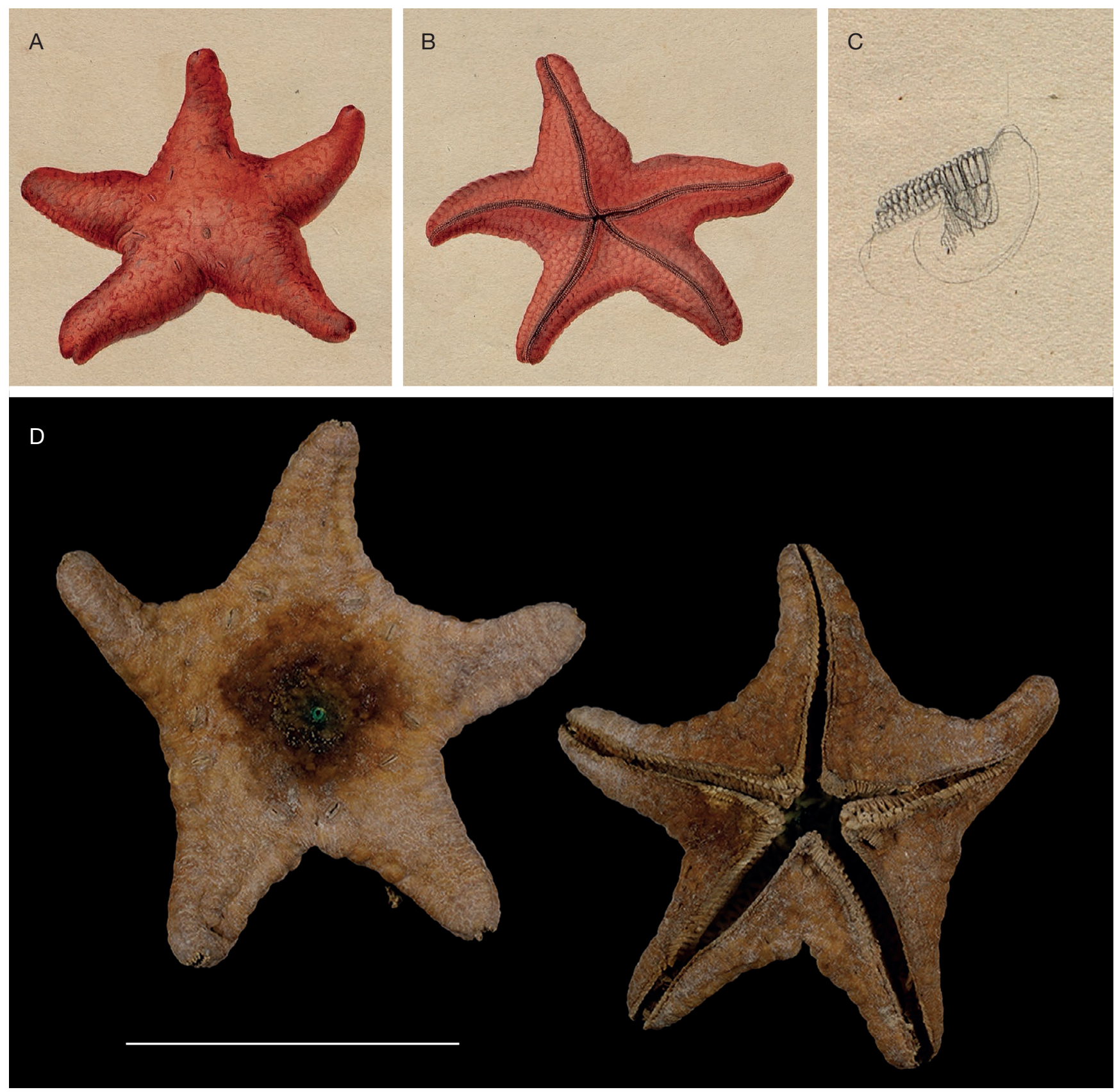

FIG. 44. - Asterias vernicina Lamarck, 1816: A, B, abactinal (A) and actinal (B) surfaces; C, adambulacral armament; D, syntype of Asterias vernicina (A-C, MHNH, Lesueur collection, 74049, details, courtesy of MHNH; D, MNHN-IE-2014-28).

\section{DISCUSSION}

Lamarck's (1816) revision of the asteroid collection of the Paris Muséum should have been more extensive. Indeed, part of the asteroid material collected in the South Seas by Péron and Lesueur during the Baudin expedition was not included in his revision although having been received and sorted by him in 1804 (Jangoux 2021). Fortunately, Lesueur drew with great precision each asteroid species collected during the expedition, thus creating a pictorial register allowing them to be identified.

Comparative studies of Lamarck's description, Lamarck's type specimens and Lesueur drawings have allowed to reconsider the status of some Lamarckian species. Current and revised status are summarised in Table 2 .

Table 3 brings together the 47 species of asteroids presented previously: 31 species described by Lamarck in his 1816 publication (respectively, 21 species from the South Seas, four South Seas varieties erected into species, and seven species from elsewhere) and 16 additional species from the South Seas which reached the Museum in 1804 but were described by post Lamarckian authors. Péron and Lesueur were by far the main collectors as they brought back to Paris 39 different species, all from the South Seas, among which 36 were new to Science. By chance, this number corresponds to the number 
TABLE 2. - Recapitulation of the taxonomic changes proposed in the present paper. See text and Table 3 for detail.

\begin{tabular}{lll}
\hline Original name & Older status & Current status \\
\hline calcar var. quinqueangula, Asterias n. syn. & Patiriella regularis (Verrill, 1867) & Parvulastra exigua (Lamarck, 1816) \\
calcitrapa var. 1, Asterias n. syn. & Nomen dubium & Bollonaster pectinatus (Sladen, 1883) \\
calcitrapa var. 2, Asterias n. syn. & Nomen dubium & Astropecten vappa Müller \& Troschel, 1843 \\
cuspidata, Asterias & Goniaster tessellatus (Lamarck, 1816) & Mediaster cuspidatus (Lamarck, 1816) n. comb. \\
lamarckii, Astrogonium n. syn. & Pentagonaster lamarcki (Müller \& Trochel, 1842) Goniaster tessellatus Lamarck, 1816 & Protoreaster lincki (Blainville, 1830) \\
nodosa var. 3, Asterias n. syn. & Protoreaster nodosus (Linnaeus, 1758) & Tosia australis (Müller \& Troschel, 1842) \\
pentagonula, Asterias n. syn. & Anthenea chinensis Gray, 1840 & Protoreaster sp. \\
pleyadella, Asterias n. syn. & Goniodiscaster pleyadella (Lamarck, 1816) & Asteropsis carinifera (Lamarck, 1816) \\
punctata, Asterias n. syn. & Petricia vernicina (Lamarck, 1816) & Anseropoda sp. \\
rosacea var. lobis senis, Asterias n. syn. & Anseropoda rosacea (Lamarck, 1816) & Paranepanthia grandis (H.L. Clark, 1928) \\
setaceus, Asteriscus n. syn. & Asterina setacea (Müller \& Troschel, 1842) &
\end{tabular}

TABLE 3. - The Lamarckian Asteroids. Abbreviations and symbol: Död.: Döderlein; Lam.: Lamarck; M.Tr.: Müller \& Troschel; WORMS: World Register of Marine Species; * synonym; 1, collections by Péron and Lesueur and drawings by Lesueur were done between 1801 and $1804 ; \mathbf{2}$, Lesueur's drawings do not represent type specimen.

\section{Original name}

1. africanus, Asteracanthion M.Tr.

2. angulatus, Archaster M.Tr.

3. australiae, Anthenea Död.

4. calcar hexagona, Asterias Lam.

5. calcar octogona, Asterias Lam.

6. calcar quinqueangula, Asterias Lam. n. syn.

7. calcitrapa var. 1, Asterias Lam. n. syn.

8. calcitrapa var. 2, Asterias Lam. n. syn.

9. carinifera, Asterias Lam.

10. clavigera, Asterias Lam.

11. cuspidata, Asterias Lam.

12. cylindrica, Asterias (part) Lam.

13. cylindrica, Asterias (part) Lam.

14. decanus, Echinaster M.Tr.

15. discoidea, Asterias Lam.

16. echinophora, Asterias Lam.

17. exigua, Asterias Lam.

18. granifera, Asterias Lam.

19. helianthus, Asterias Lam.

20. hesperus, Archaster M.Tr.

21. lamarckii, Astrogonium M.Tr. n. syn.

22. magnificum, Astrologum M.Tr.

23. milleporella, Asterias Lam.

24. multifora, Asterias Lam.

25. muricata, Coscinasterias Verrill

26. nodosa var. 1 \& 2 , Asterias Lam.

27. nodosa var. 3, Asterias Lam n. syn.

28. obtusangula, Asterias Lam.

29. ocellifera, Asterias (part) Lam.

30. ocellifera, Asterias (part) Lam.

31. ophidiana, Asterias Lam.

32. penicillaris, Asterias Lam.

33. pentagonula, Asterias Lam. n. syn.

34. pleyadella, Asterias Lam. n. syn.

35. punctata, Asterias Lam. n. syn.

36. purpureus, Ophidiaster Perrier

37. rosacea lobis quindenis, Asterias Lam.

38. rosacea lobis senis, Asterias

39. senegalensis, Asterias Lam.

40. setaceus, Asteriscus M.Tr. n. syn.

41. striata, Asterias Lam.

42. subulata, Asterias Lam.

43. subulata, Metrodira Gray

44. tenuispina, Asterias Lam.

45. tessellata var. C \& D, Asterias Lam.

46. tyloplax, Lincka H. L. Clark

47. variolata, Asterias Lam.

48. vernicina, Asterias Lam.
Status

Marthasterias africana (M.Tr.)

Archaster angulatus M.Tr.

Anthenea australiae Död.

Meridiastra gunni (Gray)*

Meridiastra calcar (Lam.)

Parvulastra exigua (Lam.)

Bollonaster pectinatus (Sladen)

Astropecten vappa (M.Tr.)

Asteropsis carinifera (Lam.)

Mithrodia clavigera (Lam.)

Mediaster cuspidatus (Lam) n comb South Seas Péron \& Lesueur Lesueur

Dactylosaster cylindricus (Lam.)

Ophidiaster purpuratus Perrier *

Plectaster decanus (M.Tr.)

Culcita schmideliana (Bruzelius)*

Echinaster echinophorus (Lam.)

Parvulastra exigua (Lam.)

Uniophora granifera (Lam.)

Heliaster helianthus (Lam.)

Craspidaster hesperus (M.Tr.)

Goniaster tessellatus (Lam.)

Tosia magnifica (M.Tr.)

Fromia milleporella (Lam.)

Linckia multifora (Lam.)

Coscinasterias muricata Verrill

Protoreaster nodosus (Linnaeus)*

Protoreaster lincki (Blainville)

Pseudoreaster obtusangula (Lam.)

Nectria ocellifera (Lam.)

Nectria ocellata Perrier

Ophidiaster ophidianus (Lam.)

Asterinopsis penicillaris (Lam.)

Tosia australis Gray

Protoreaster sp.

Asteropsis carinifera (Lam.)

Ophidiaster hemprichi M.Tr. *

Anseropoda rosacea (Lam.)

Anseropoda sp.

Luidia senegalensis (Lam.)

Paranepanthia grandis H. L. Clark

Valvaster striatus (Lam.)

Chaetaster longipes (Bruzelius) ${ }^{\star}$

Metrodira subulata Gray

Coscinasterias tenuispina (Lam.)

Goniaster tessellatus (Lam.)

Hacelia tyloplax (H. L. Clark)

Nardoa variolata (Bruzelius)

Petricia vernicina (Lam.)
Photos Photos

Origin Collector(s) ${ }^{1} \quad$ Drawings ${ }^{1}$ (type) (other)

South Africa Péron \& Lesueur Lesueur South Seas Péron \& Lesueur Lesueur W Australia Péron \& Lesueur Lesueur SW Australia Péron \& Lesueur Lesueur SW Australia Péron \& Lesueur Lesueur SW Australia Péron \& Lesueur Lesueur South Seas Péron \& Lesueur Lesueur South Seas Péron \& Lesueur Lesueur South Seas Péron \& Lesueur Lesueur Mauritius Péron \& Lesueur Mauritius Péron \& Lesueur Lesueur Mauritius Péron \& Lesueur Lesueur South Seas Péron \& Lesueur Lesueur South Seas Péron \& Lesueur Lesueur Brazil Unknown

SW Australia Péron \& Lesueur Lesueur South Seas Péron \& Lesueur Lesueur ?Chile Unknown Bruguière South Seas Péron \& Lesueur Lesueur2 Atlantic

South Seas Péron \& Lesueur Lesueur South Seas Péron \& Lesueur Lesueur South Seas Péron \& Lesueur Lesueur South Seas Péron \& Lesueur Lesueur South Seas Péron \& Lesueur Lesueur Mauritius Péron \& Lesueur South Seas Péron \& Lesueur Lesueur South Seas Péron \& Lesueur Lesueur South Seas Péron \& Lesueur MediterraneaUnknown

South Seas Péron \& Lesueur Lesueur South Seas Péron \& Lesueur Lesueur South Seas Péron \& Lesueur Lesueur South Seas Péron \& Lesueur Lesueur Mauritius Péron \& Lesueur Lesueur South Seas Péron \& Lesueur Lesueur South Seas Péron \& Lesueur Lesueur

West Indies Adanson

South Seas Péron \& Lesueur Lesueur Mauritius Mathieu MediterraneaUnknown South Seas Péron \& Lesueur Lesueur Atlantic Unknown

South Seas Péron \& Lesueur Lesueur Mauritius Unknown Lesueur2 South Seas Péron \& Lesueur Lesueur

\begin{tabular}{|c|c|}
\hline - & - \\
\hline- & - \\
\hline MNHN & - \\
\hline MNHN & - \\
\hline MNHN & - \\
\hline MNHN & - \\
\hline- & - \\
\hline- & - \\
\hline MNHN & - \\
\hline MNHN & - \\
\hline MNHN & \\
\hline MNHN & - \\
\hline MNHN & - \\
\hline- & - \\
\hline- & - \\
\hline MNHN & - \\
\hline MNHN & - \\
\hline MNHN & - \\
\hline- & - \\
\hline- & - \\
\hline MNHN & - \\
\hline- & - \\
\hline MNHN & - \\
\hline- & - \\
\hline- & - \\
\hline- & - \\
\hline- & MNHN \\
\hline MNHN & - \\
\hline MNHN & - \\
\hline- & MNHN \\
\hline- & WORMS \\
\hline- & - \\
\hline- & - \\
\hline MNHN & - \\
\hline MNHN & - \\
\hline- & - \\
\hline MNHN & - \\
\hline- & - \\
\hline MNHN & - \\
\hline- & - \\
\hline MNHN & - \\
\hline- & MNHN \\
\hline- & - \\
\hline- & MNHN \\
\hline MNHN & - \\
\hline- & - \\
\hline- & - \\
\hline MNHN & - \\
\hline
\end{tabular}


of new species of asteroids from the South Seas estimated by Lamarck in his 1804 report. Clearly the Paris Muséum had at the time the first and quite exhaustive collection of shallow water asteroids from Australian seas.

\section{Acknowledgements}

I am grateful to Gérard Breton and Jacqueline Bonnemains, former director and curator of the Le Havre Museum, respectively, and to Gabrielle Baglione, current curator of Lesueur drawings collection, for their kind welcome and friendly help; to Professor John Lawrence for his interest and linguistic assistance; to Chris Mah and Loïc Villier for their effective comments; to Laure Desutter and Anne Mabille for their editorial help. The MNHN gives access to the collections in the framework of the RECOLNAT national Research Infrastructure.

\section{REFERENCES}

Bonnemains J. 1995. - Origine de la collection Lesueur. Annales du Musée du Havre 49: 4-23.

BRUGUiÈRE J. G. 1791. — Helminthology [y compris les zoophytes échinodermes]. Tableau encyclopédique et méthodique des troi Règnes de la Nature [...], 1. Pancoucke, Paris, $189 \mathrm{pl}$. [The asteroid figured by Bruguière were identified by Bory de Saint Vincent in 1827 in an appendix of Bruguière's Tableau.]

Clark A. M. 1989. - An index of recent Asteroidea. Part 1: Paxillosida and Notomyotida, in Jangoux M. \& LAWrenCE J. M. (eds), Echinoderm Studies, vol. 3. Balkema, Rotterdam: 225-347.

Clark A. M. 1993. - An index of recent Asteroidea. Part 2: Valvatida, in JANGOUX M. \& LAWRENCE J. M. (eds), Echinoderm Studies, vol. 4. Balkema, Rotterdam: 187-366.

Clark A. M. 1996. - An index of recent Asteroidea. Part 3: Velatida and Spinulosida, in Jangoux M. \& LaWrence J. M. (eds), Echinoderm Studies, vol. 5. Balkema, Rotterdam: 183-250.

Clark A. M. \& CourTMAn-STOCK J. 1976. - The Echinoderms of southern Africa. Publ. n. 766, British Museum (natural History), London, $277 \mathrm{p}$.

Clark A. M. \& Downey M. E. 1992. - Starfishes of the Atlantic. Chapman and Hall, London, 565p.

Clark A. M. \& MAH CH. 2001. - An index of recent Asteroidea. Part 4: Forcipulata and Brisingida, in JANGOUX M. \& LAWRENCE J. M. (eds), Echinoderm Studies, vol. 6. Balkema, Rotterdam: 229-347.

Clark H. L. 1914. - The echinoderms of the Western Australian Museum. Records of the Western Australian Museum 1: 132-173.

Clark H. L. 1916. - Report on the sea-lilies, starfishes, brittle-stars and sea-urchins obtained by the F.I.S. Endeavour on the coasts of Queensland, New South Wales, Tasmania, Victoria, South Australia and Western Australia. Biological Results of the F.I.S. Endeavour 4 (1): 1-123.

Dartnall A. J. 1969. - New Zealand seastars in Tasmania. Papers and Proceedings of the royal Society of Tasmania 103: 53-55.

Dartnall A. J. 1971. - Australian sea stars of the genus Patiriella (Asteroidea, Asterinidae). Proceedings of the Linnean Society of New South Wales 96: 41-49.

DöDERLEIN L. 1915. — Die Arten der Asteroidea. Gattung Anthenea. Jahrbuchern des Nassauischen Vereins fur Naturkunde in Wiesbaden 68: 21-55

DöDERLEIN L. 1917. — Die Asteriden der Siboga-expedition 1. Die Gattung Astropecten und ihre Stammesgeschichte. SibogaExpedition 46a: 1-190. https://doi.org/10.5962/bhl.title.11319

GRAY J. E. 1840. - A synopsis of the genera and species of Hypostoma (Asterias Linnaeus). Annals and Magazine of natural History 6: 175184 and 275-290. https://doi.org/10.1080/03745484009443282
JANGOUX M. 1984. — Les astérides (échinodermes) des Terres australes ramenées par l'expédition Baudin (1800-1804) : catalogue commenté des dessins inédits de Charles-Alexandre Lesueur conservés au Muséum d'Histoire naturelle du Havre. Bulletin trimestriel de la Société géologique de Normandie et des Amis du Muséum du Havre 71 (4): 25-56.

JANGOUX M. IN PRESS. - The unpublished reports of Lamarck and the fate of the invertebrate collection from the Southern Lands, in Fornasiero J. \& West-SOOBY J. (eds), François Péron and the Figure of the scientific Voyager, Mile End, Wakesfield Press, Australia.

LAMARCK J. B. DE 1816. - Histoire naturelle des Animaux sans Vertèbres, Tome 2. Paris, Verdière: 547-568. https://www.biodiversitylibrary.org/page/13299321

LiaO Y. \& CLARK A. M. 1995. - Echinoderms of Southern China. Beijing, Science Press, 614 p.

LINCK J. H. 1733. - De stellis marinis liber singularis. Lipsiae, 151 p. https://doi.org/10.5962/bhl.title.120095

LORIOL P. DE 1885. - Catalogue raisonné des échinodermes recueillis à l'île Maurice par M. V. de Robillard. 2. Stellérides. Mémoires de la Société de Physique et d'Histoire naturelle de Genève 29 (4): 1-84.

McKnight D. G. 1977. - Classification of recent paxillosid sea stars (Asterozoa, Echinodermata). Records of the New Zealand oceanographic Institute 3: 113-119.

Madsen F. J. 1950. - The echinoderms collected by the Atlantide expedition. 1. Asteroidea. Atlantide Report 1: 167-222.

MorTensen T. 1933. - Echinoderms of South Africa (Asteroidea and Ophiuroidea). Videnskabelige Meddelelser fra Dansk naturhistorisk Forening 93: 215-400.

MÜller J. \& Troschel H. 1840. - Ueber die Gattungen der Asterien. Archiv für Naturgeschichte 6: 318-326.

Müller J. \& Troschel H. 1842. - System der Asteriden. Braunschweig, 134 p. https://www.biodiversitylibrary.org/page/12100281

Müller J. \& Troschel H. 1843. — Neue Beiträge zur Kenntnis der Asteriden. Archiv für Naturgeschichte 9: 113-131.

O'Loughlin P. M. \& Waters J. M. 2004. - A molecular and morphological revision of genera of Asterinidae (Echinodermata: Asteroidea). Memoirs of Museum Victoria 61: 1-40. https://doi. org/10.24199/j.mmv.2004.61.1

PERRIER E. 1869. - Recherches sur les Pédicellaires et les Ambulacres des Astéries et des Oursins. Masson, Paris, 188 p. (the part on asteroids is also published in: Annales des Sciences naturelles 13 [1]: 1-81). https://doi.org/10.5962/bhl.title.14144

Perrier E. 1875. - Révision de la Collection de Stellérides du Muséum d'Histoire naturelle de Paris. $384 \mathrm{p}$, Reinwald, Paris (also published in: Archives de Zoologie expérimentale et générale vol. 4 [1875]: 263-449, and vol. 5 [1876]: 1-104).

Rowe F. W. E. \& GATES J. 1995. — Echinodermata, in Wells A. (ed.), Zoological Catalogue of Australia (Melbourne, CSIRO) 33: $1-510$.

SUKARNO R. \& JANGOUX M. 1977. — Révision du genre Archaster Müller \& Troschel (Echinodermata: Asteroidea: Archasteridae). Revue de Zoologie africaine 91 (4): 817-844.

Verrill A. E. 1867. - Notes on Radiata in the Museum of Yale College. Transactions Connecticut Academy of Arts and Sciences 1: 247-351.

Wright A. C, Pérez-Portela \& Griffiths C. L. 2016. — Determining the correct identity of South African Marthasterias (Echinodermata: Asteroidea). African Journal of marine Sciences 38: 443-455. https://doi.org/10.2989/1814232X.2016.1222308

ZEIDLER W. \& Rowe F. W. E. 1986. - A revision of the southern Australian starfish genus Nectria (Asteroidea: Oreasteridae), with the description of a new species. Records of the South Australian Museum 19 (9): 117-138.

Submitted on 24 February 2020; accepted on 11 May 2020; published on 11 May 2021. 